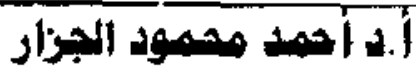

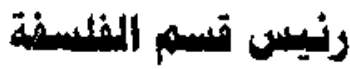

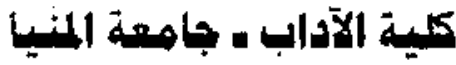

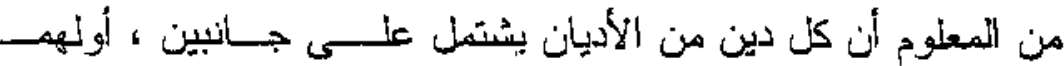

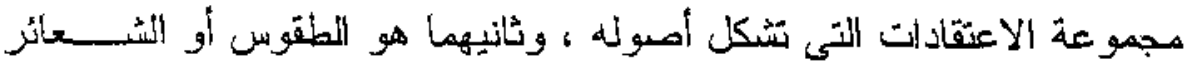

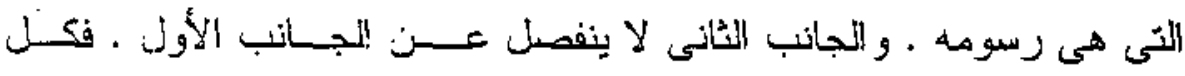

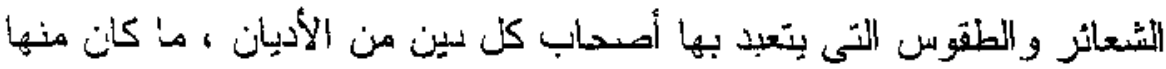

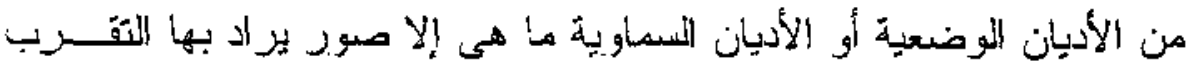

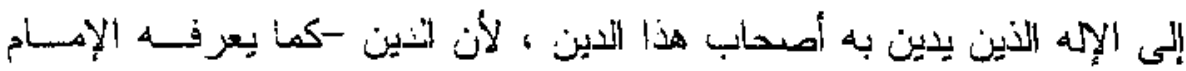

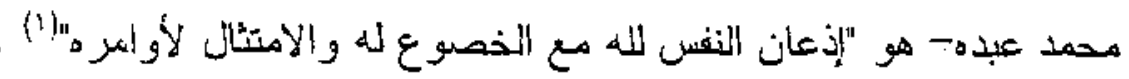

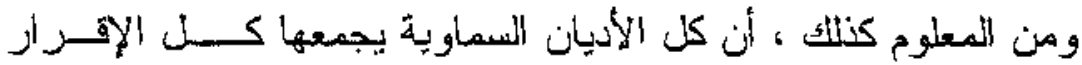

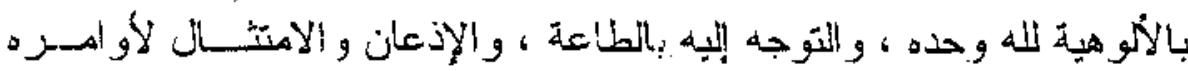

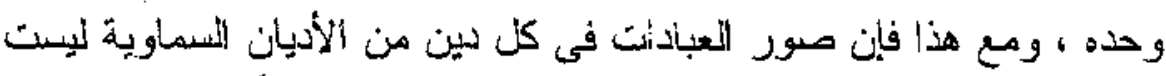

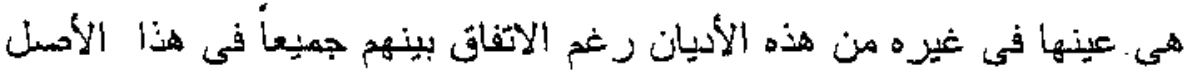

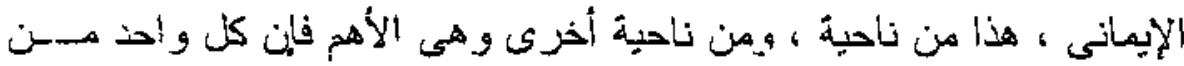

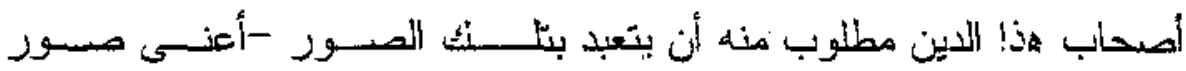

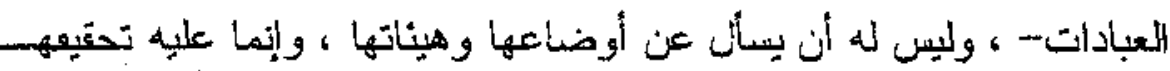

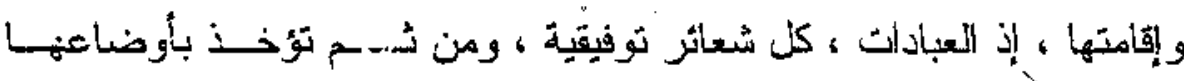

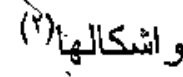

عبده (الأستاذ الإملم) : تفسير سورة الفاتحة وجزء عم ، مبعة جريدة الجمهوريــة

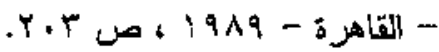

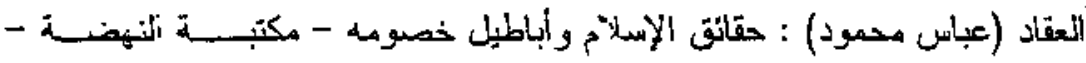

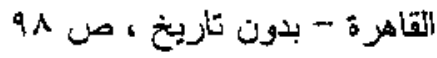


وإِذا كإنت كل المعبادأت من حيث هى رسوم أو أوضياع هى ثُعائر

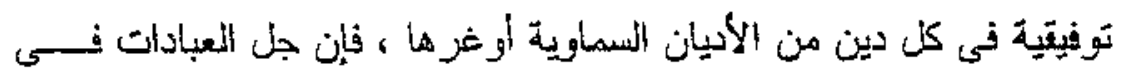

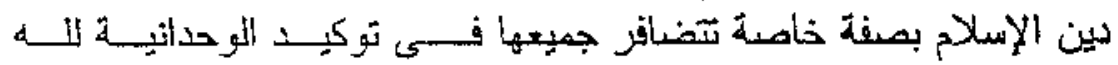

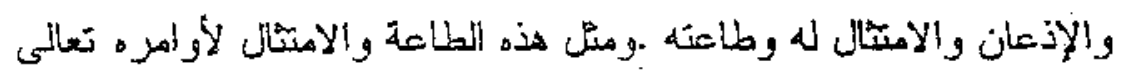

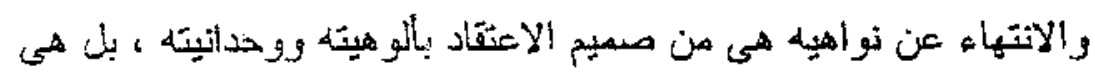

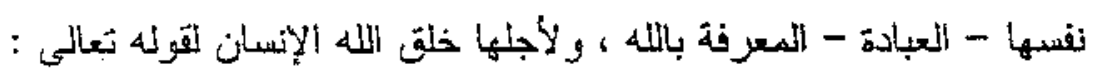

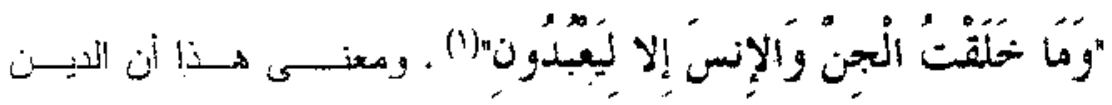

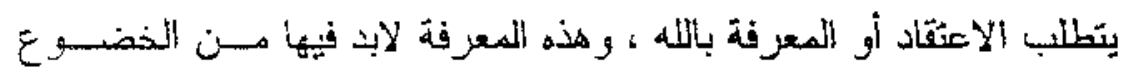

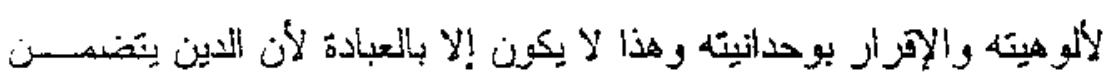

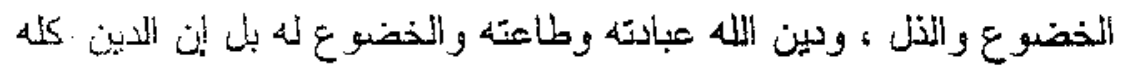

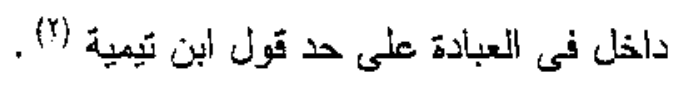

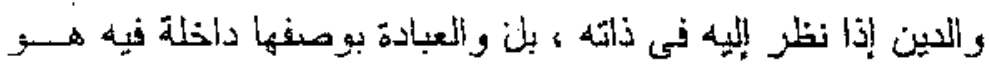

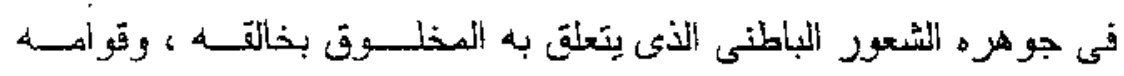

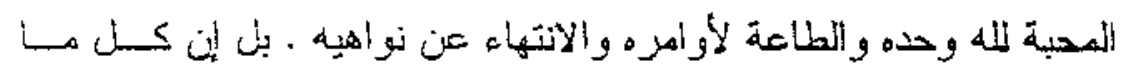

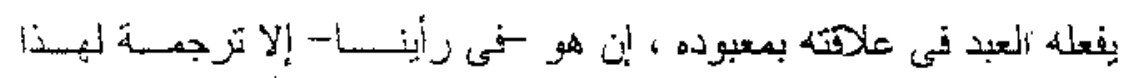

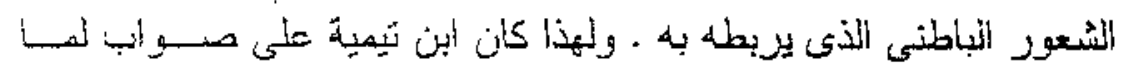

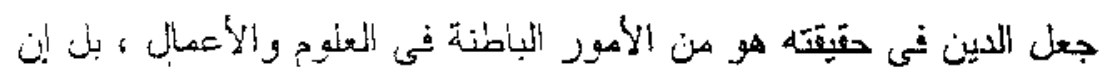

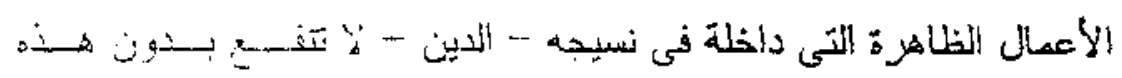

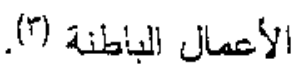

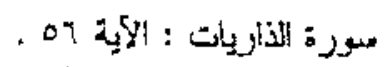

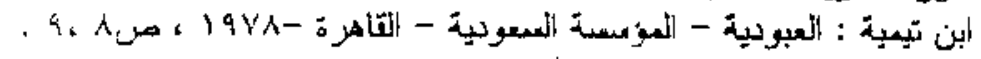

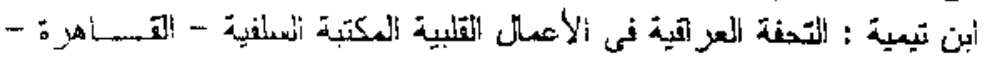

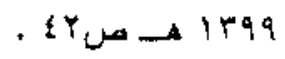




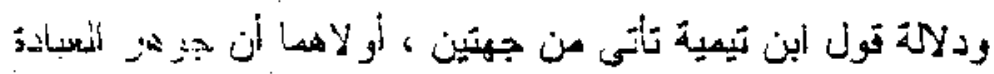

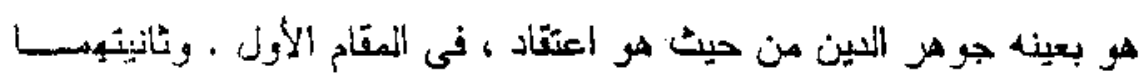

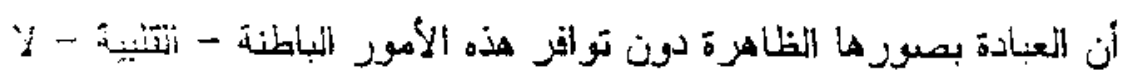

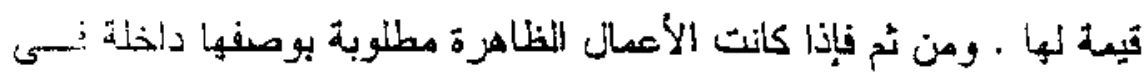

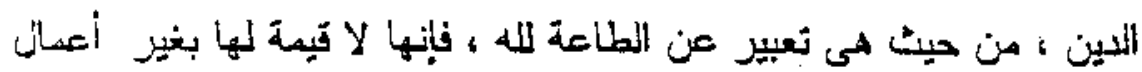

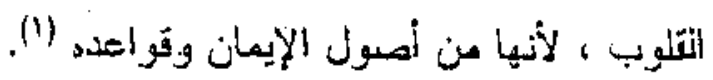
ومن هذه الجهة بالذات تكمن حقيقة العبادة فى الإسلام ، من حيث

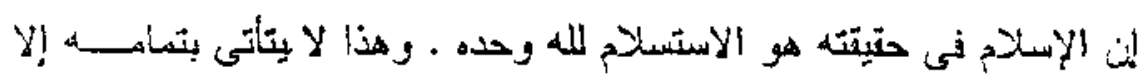

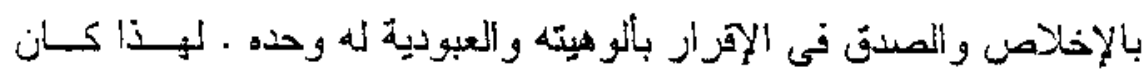

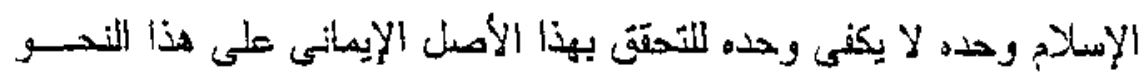

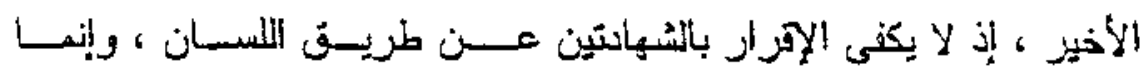

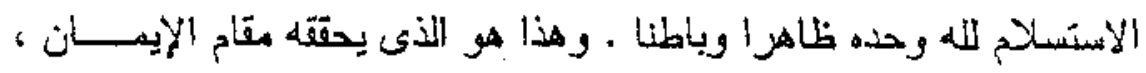

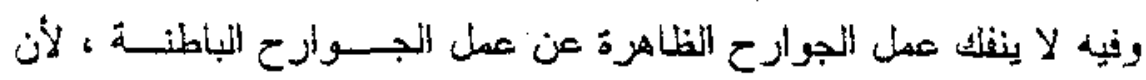

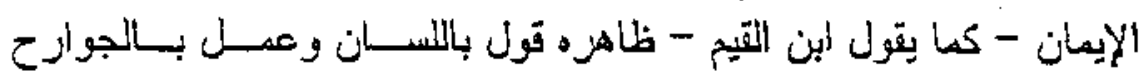

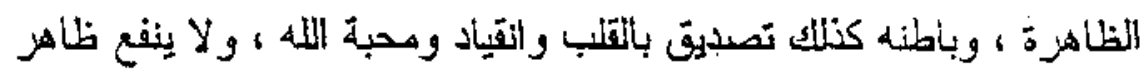

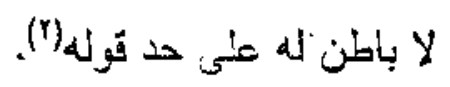

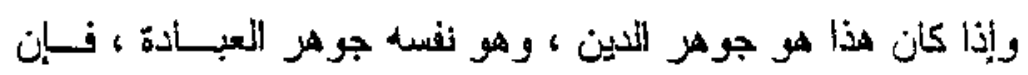

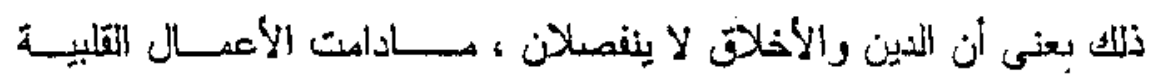

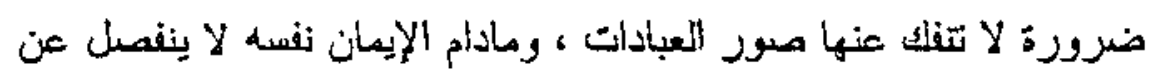

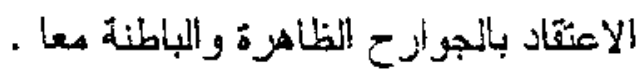

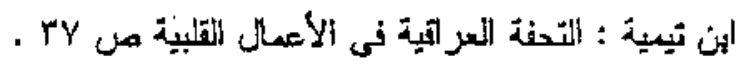

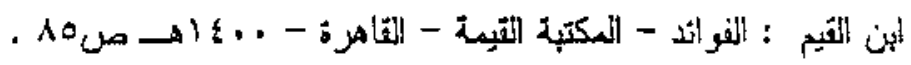




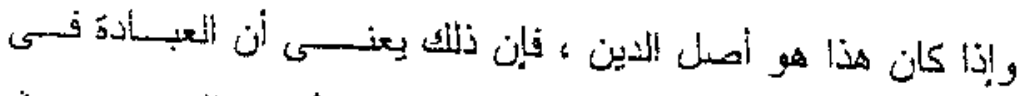

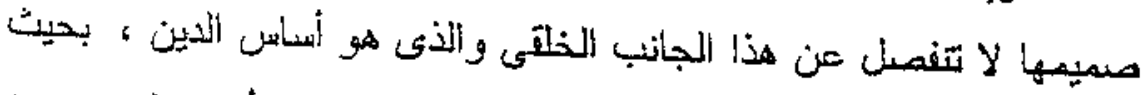

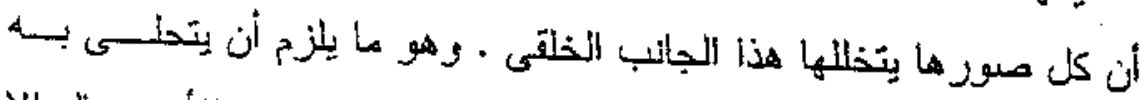

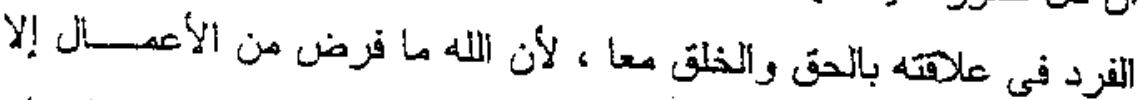

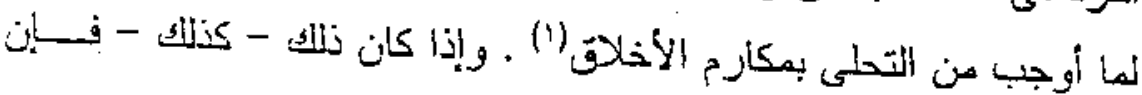

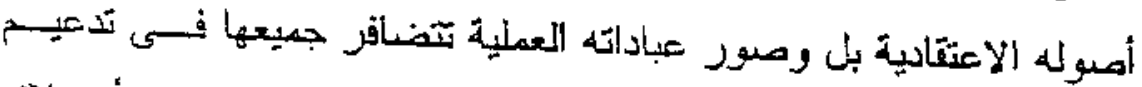

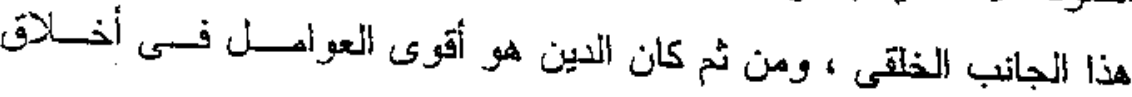

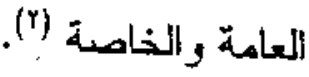

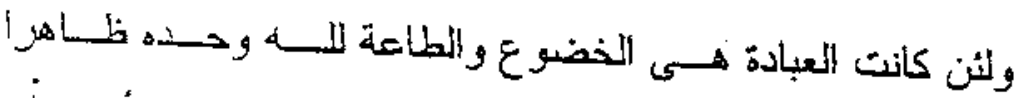

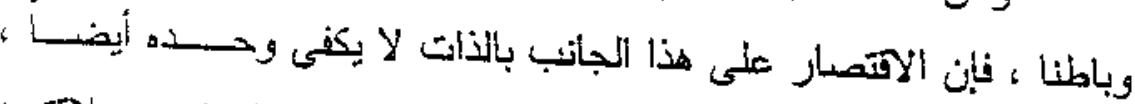

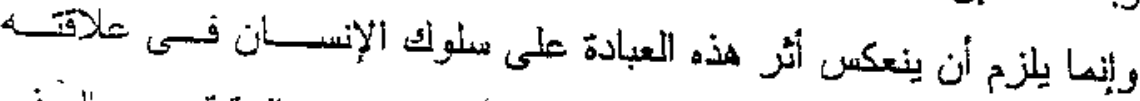

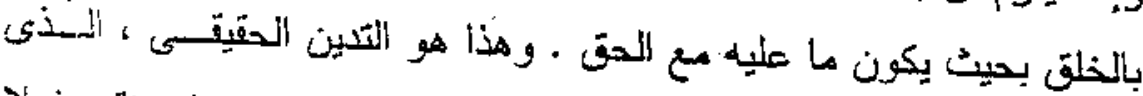

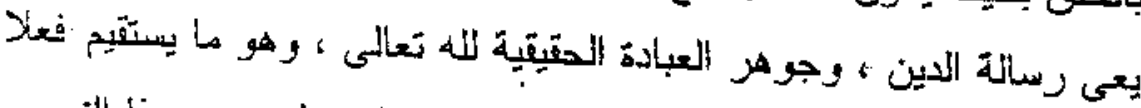

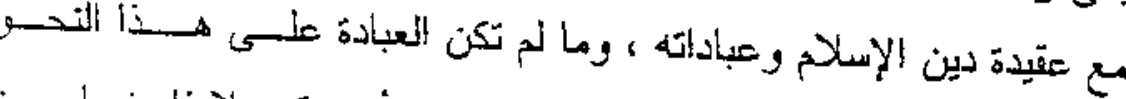

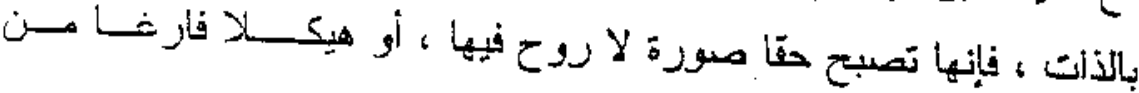

(") المخمون

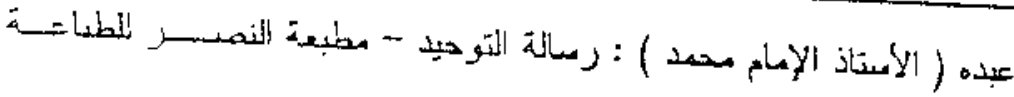

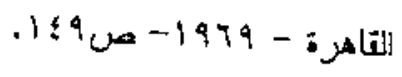

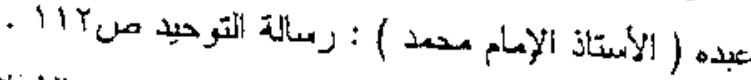

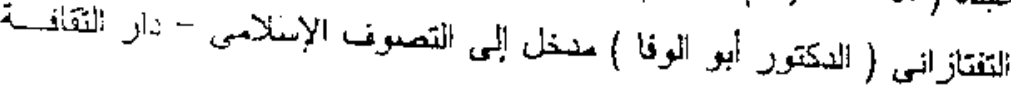

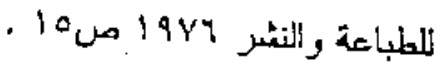




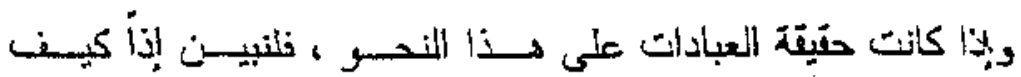

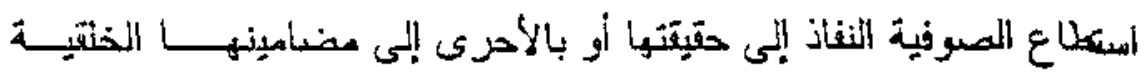

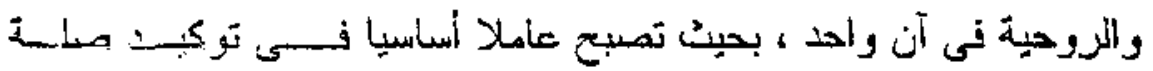
الإنسان بالحق تعالى من ناحية ، وبحيث تكون كنللك تحقيقا للحياة الخنقيَة مع الخلق هن نالحية أخرى .

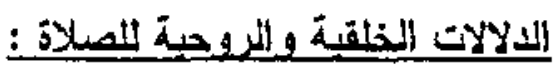

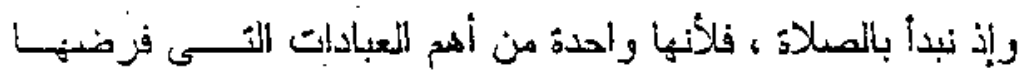

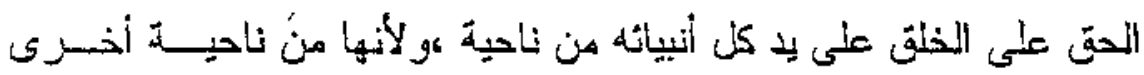
تحثل مكانة خاصدة في دين الإنسلام بوصفه خاتم الأديان جميعهيا بذليل أن

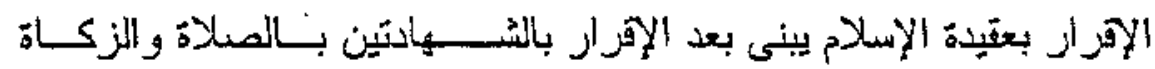

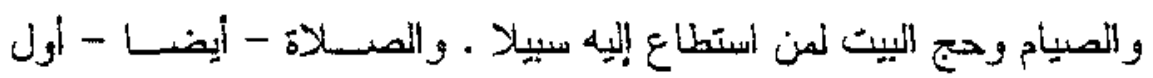

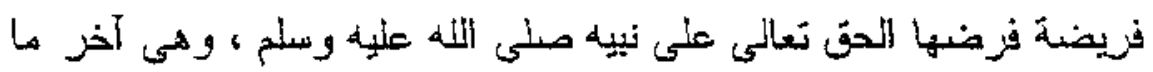

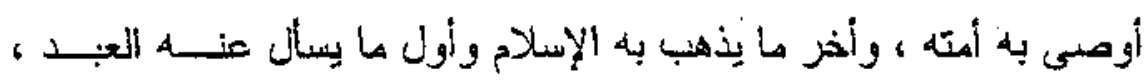

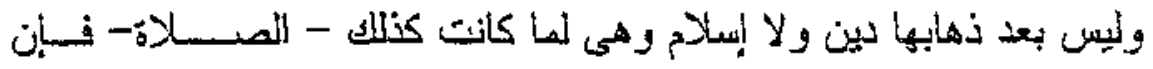

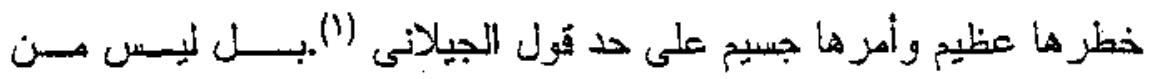

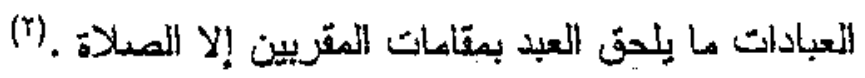
و هى فضلا عن زلك كله تعد وأحدة هن أهم العبادات ، فقد الجتهع

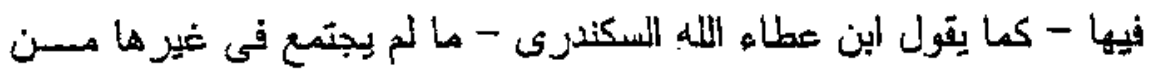

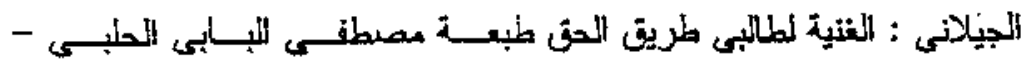

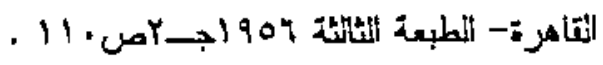

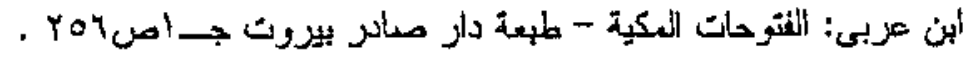




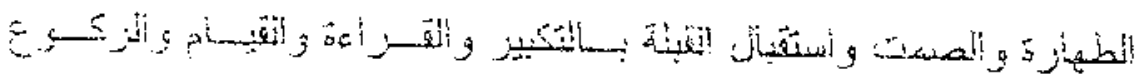

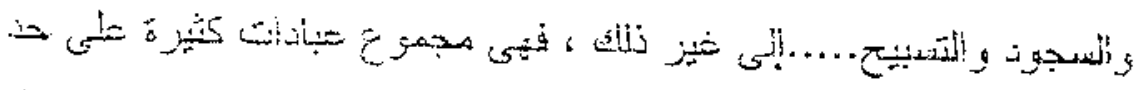

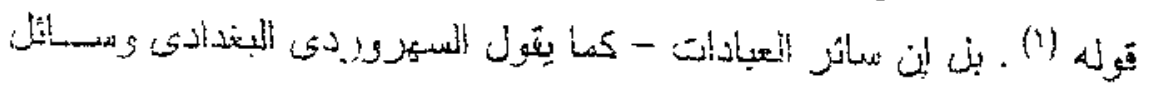

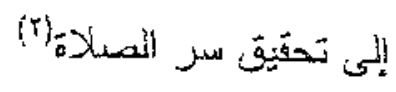

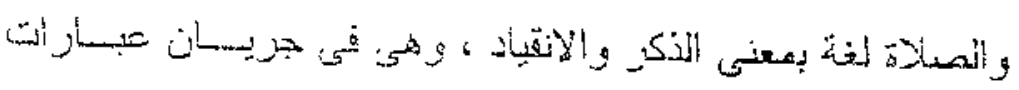

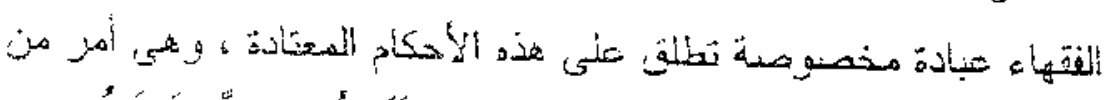

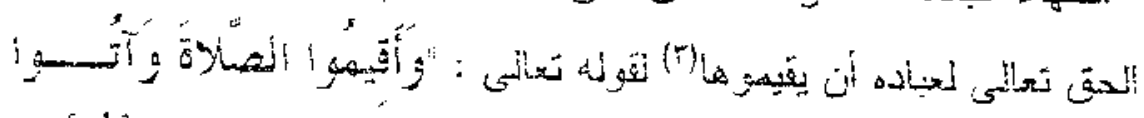

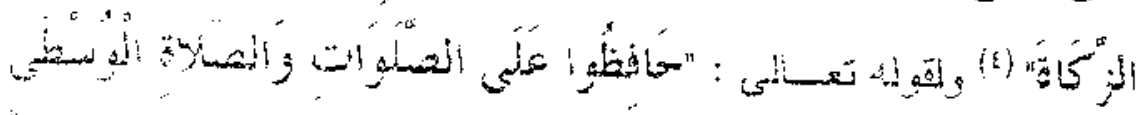

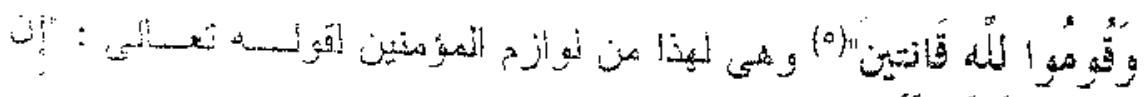

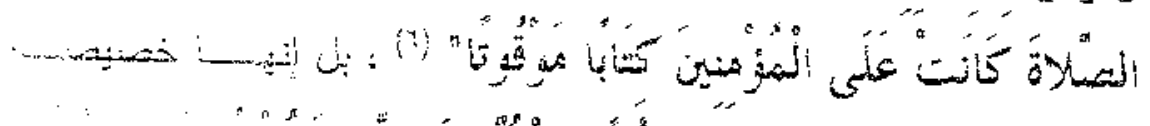

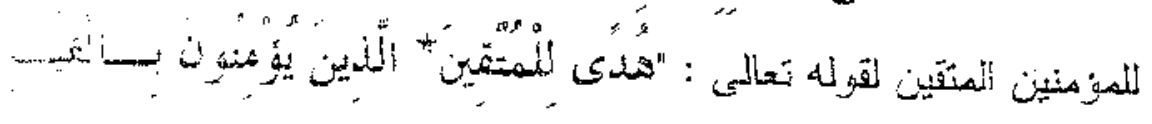

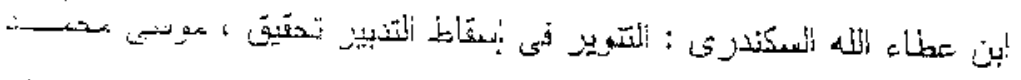

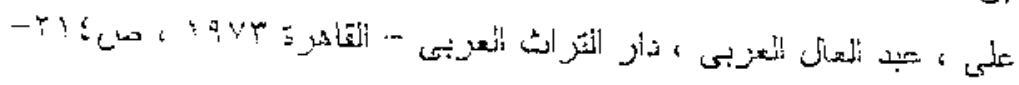
Y 10

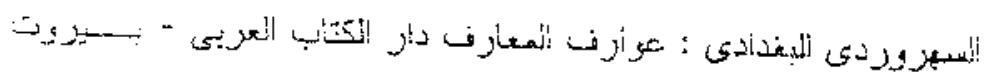

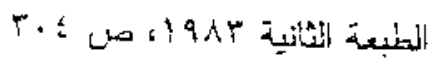

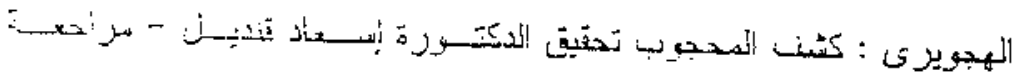

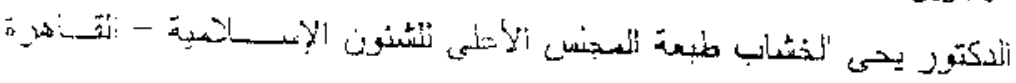

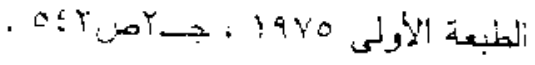

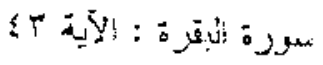

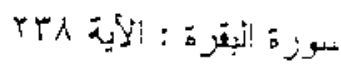

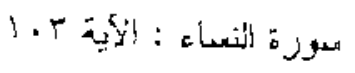




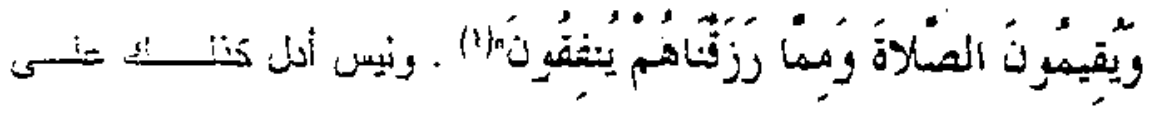
منزلة الصلاة فى الإسلاد من قول اللنبى صلى ألله عنيه وسلم مبيين المرجزئ.

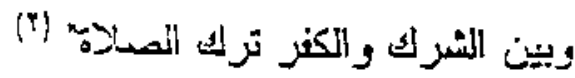

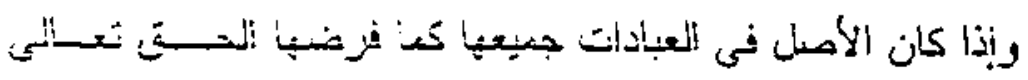

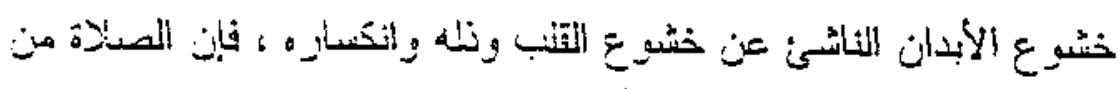

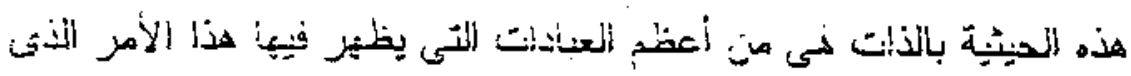

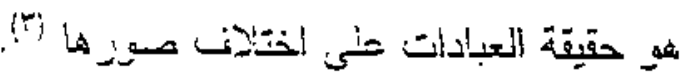

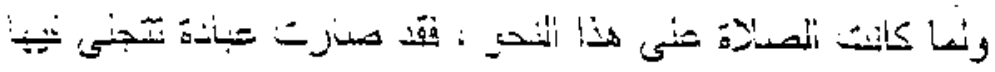

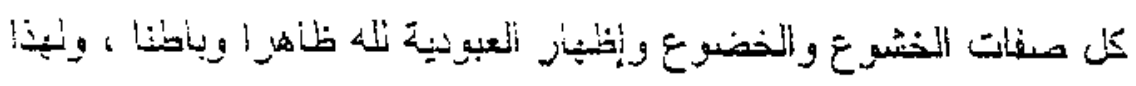

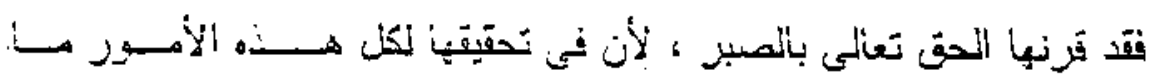

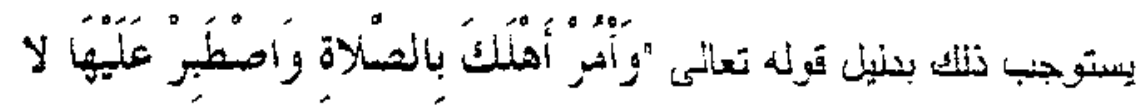

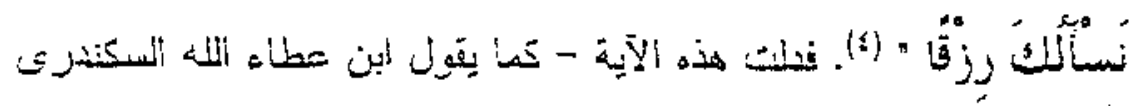

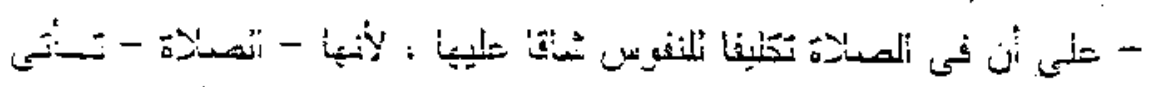

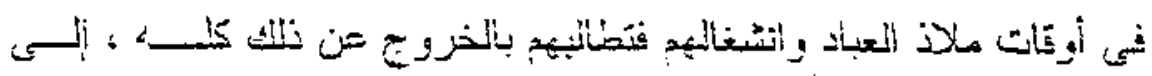

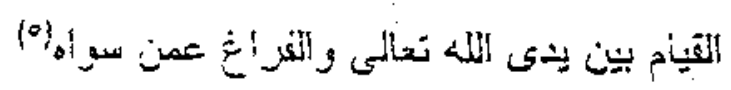

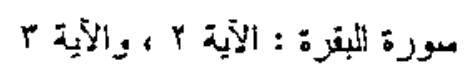

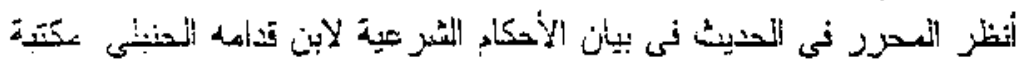

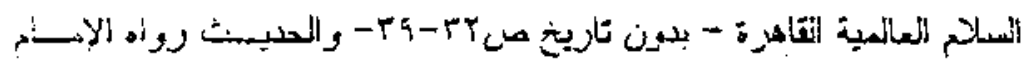

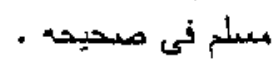

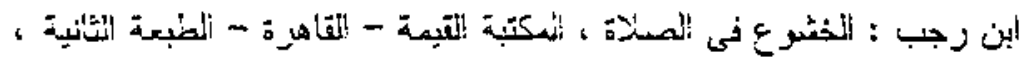

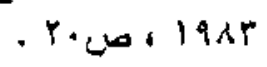

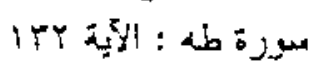

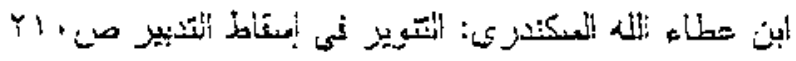




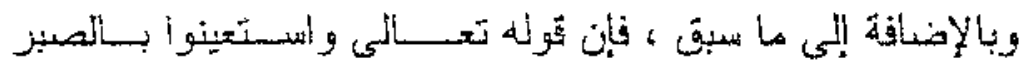

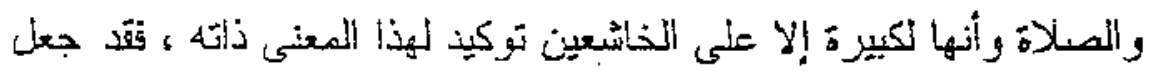

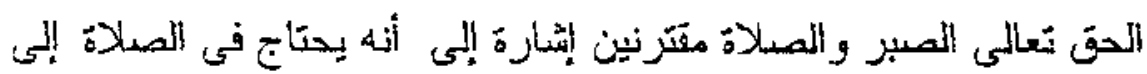

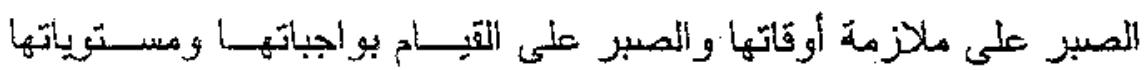

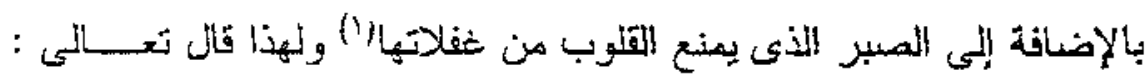

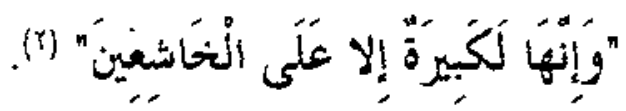

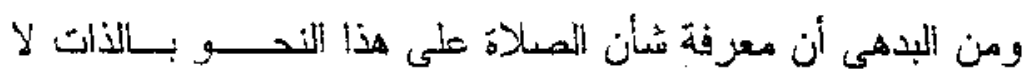

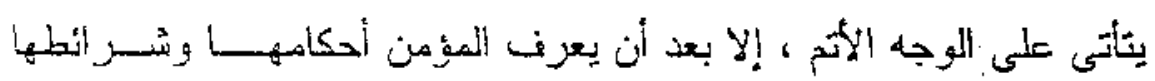

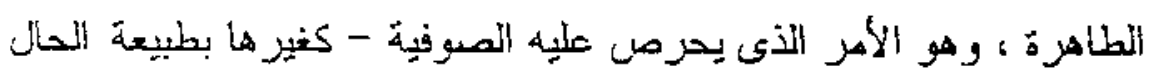

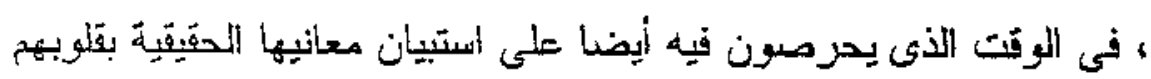

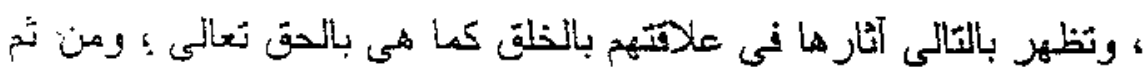

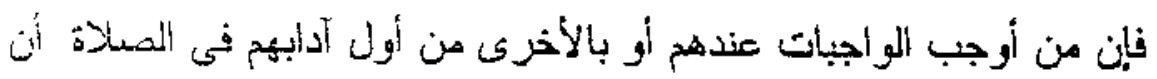

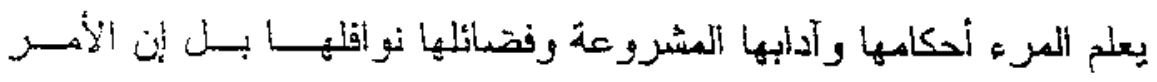

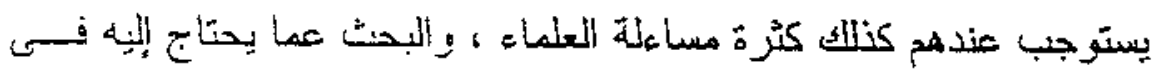

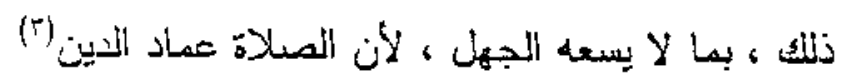

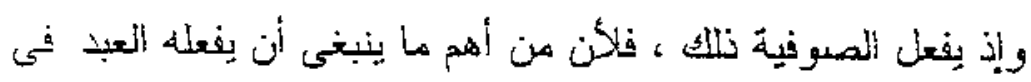

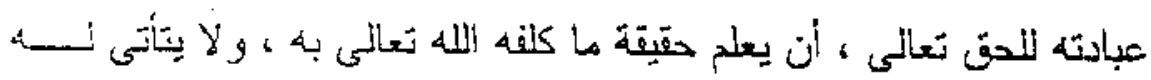

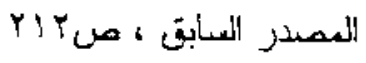

$$
\begin{aligned}
& \text { سيرة اللبترة: : الأية م؛ . }
\end{aligned}
$$

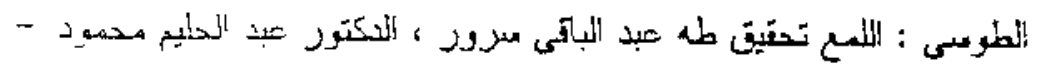

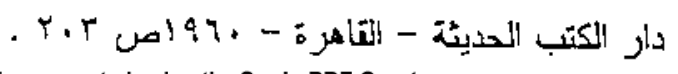


هذا الأمر ، إلا بالفقه في أحكام المعيادات أو لا إذ لا تصبح المبادة إلا بعــــ الثقة) (1)

لكن الصرفية حين يفقهون أحكام المصلاة لا يتوثفون عند حد الئلم

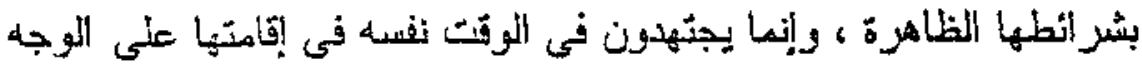

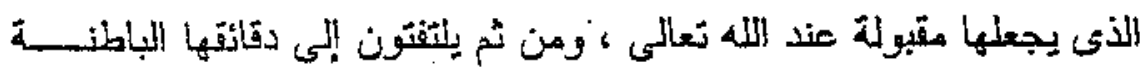

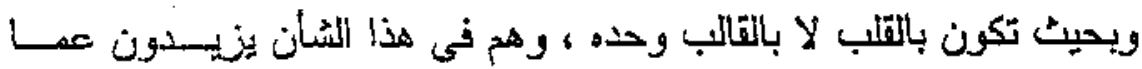

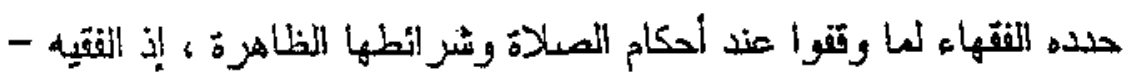

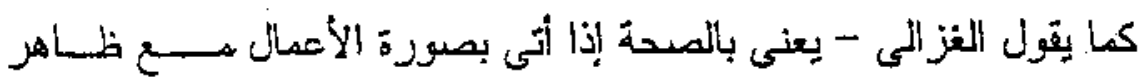

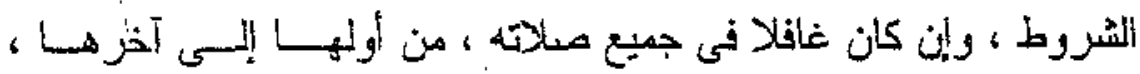

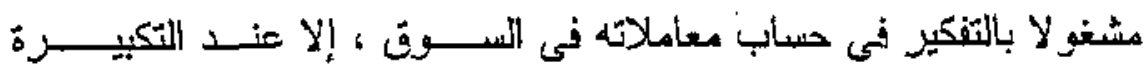

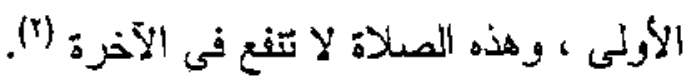

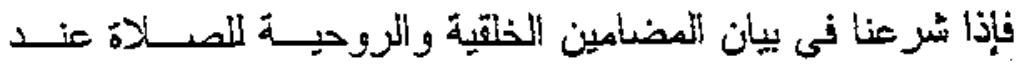

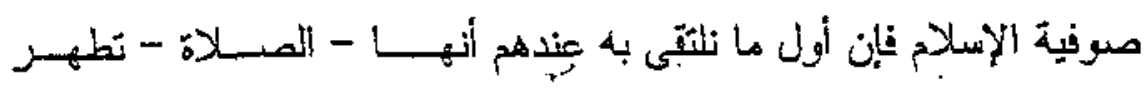

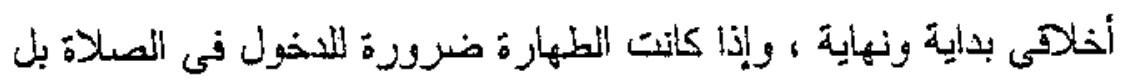

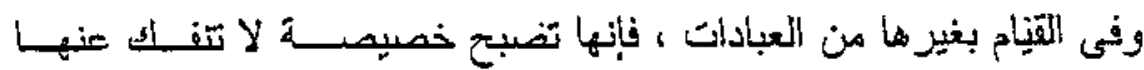

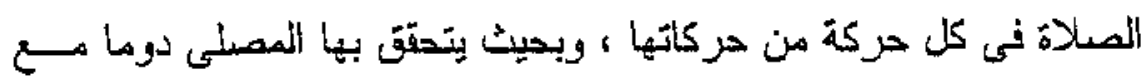

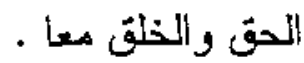

البغدادي ( الخطيب ) : الفته والفقيه - تحتين إبساعيل الأنصارى - مكتبسة

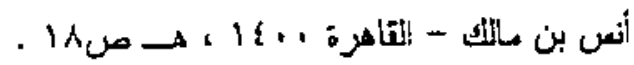

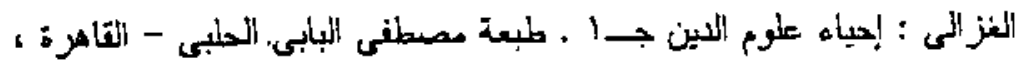




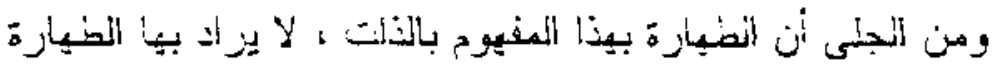

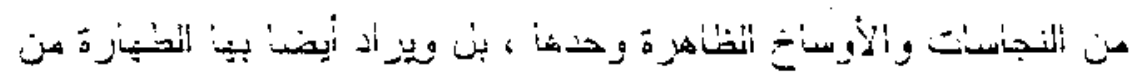

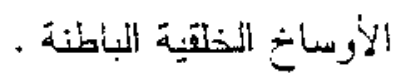

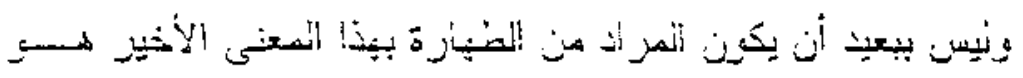

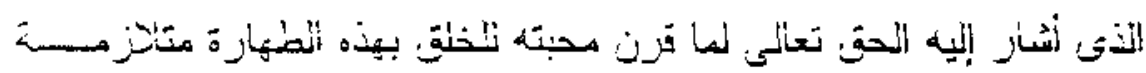

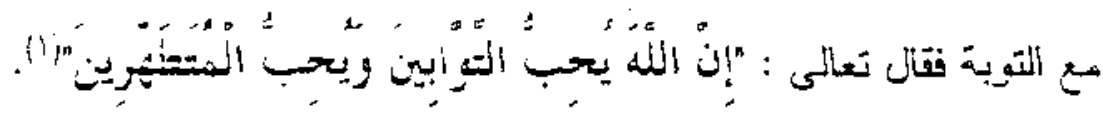

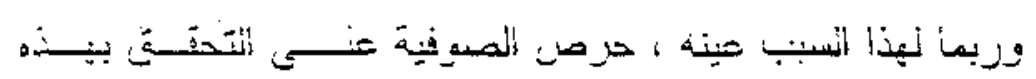

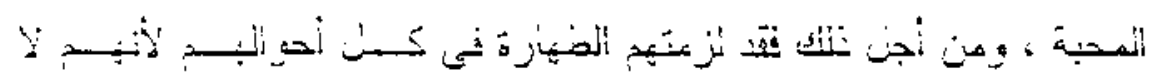

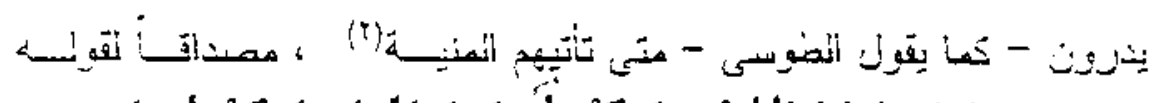

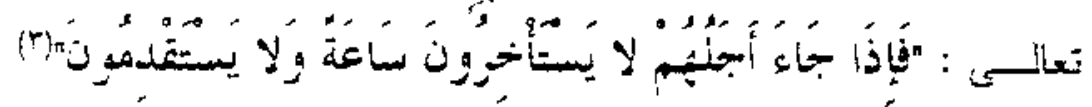

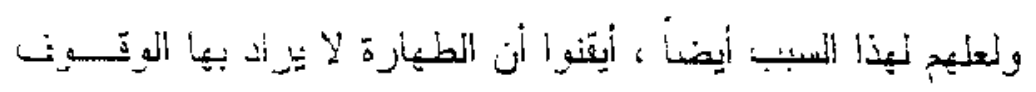

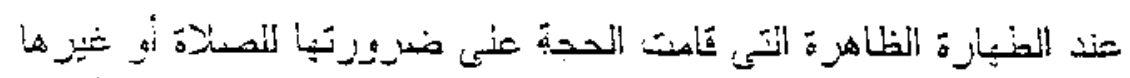

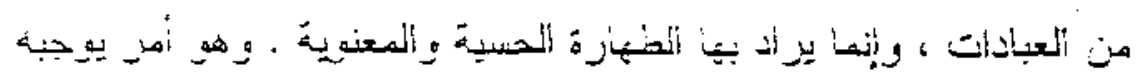

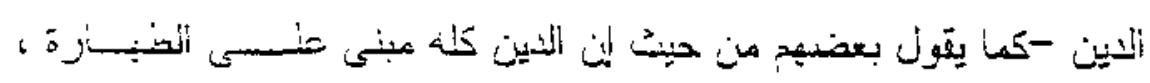

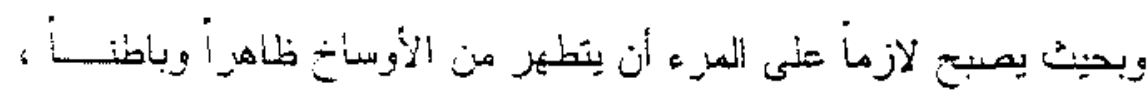

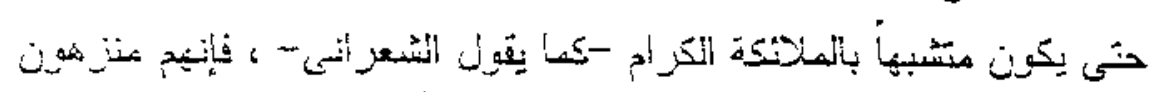

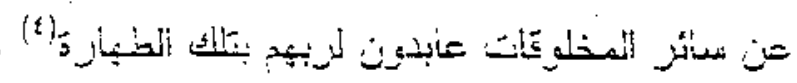

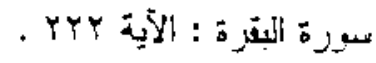

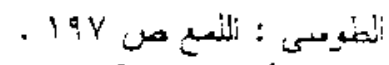

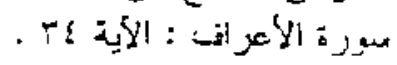

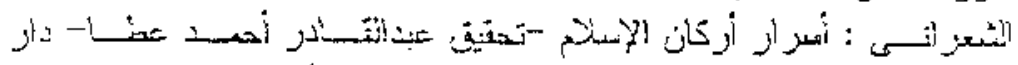

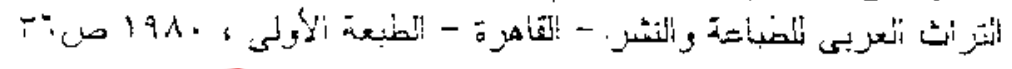




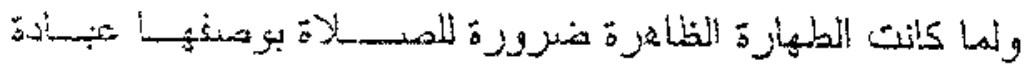

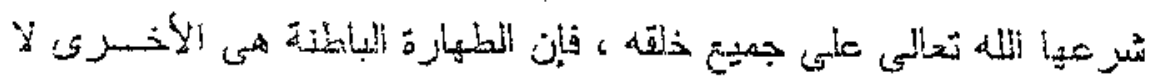

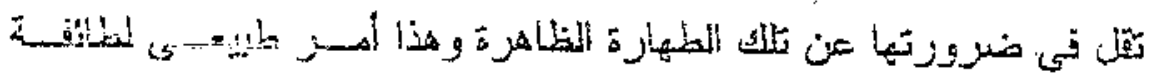

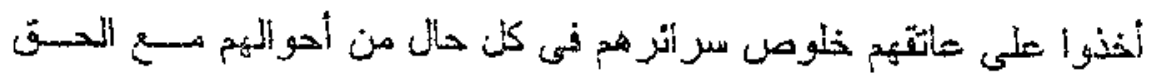

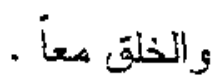

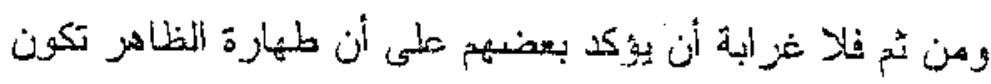

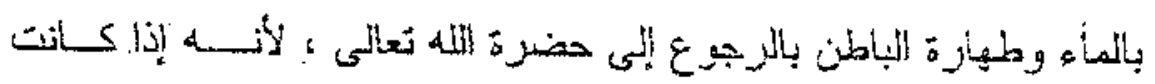

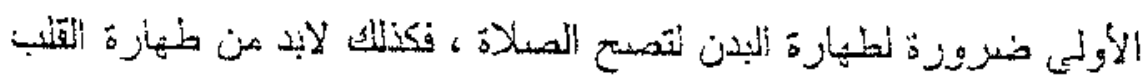

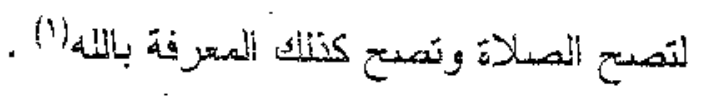

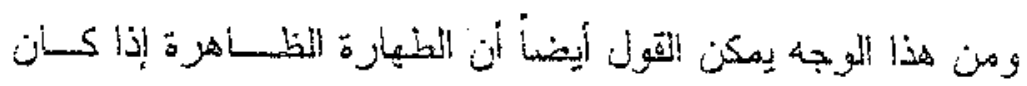

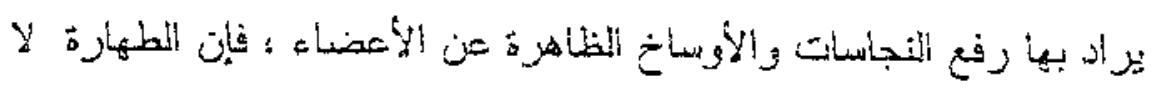

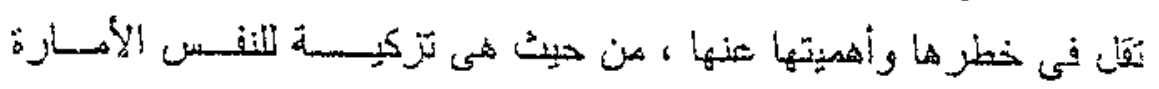

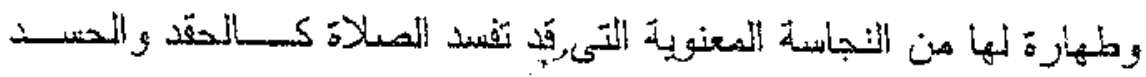

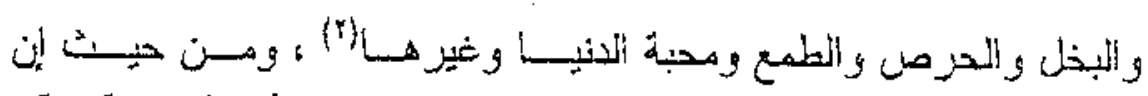

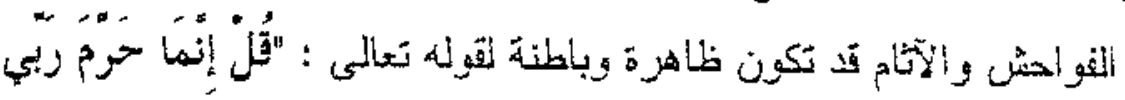

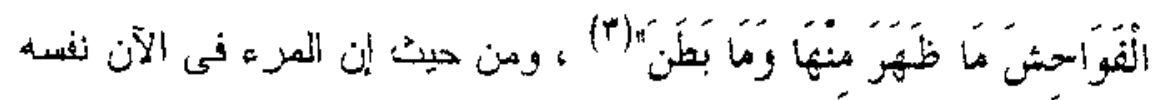

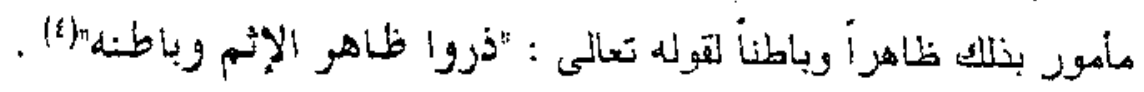

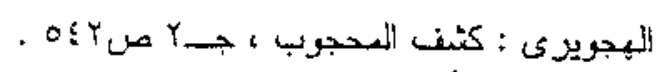

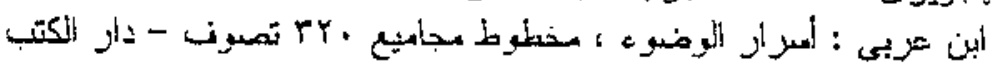

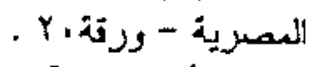

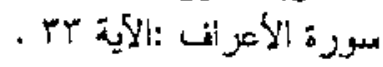

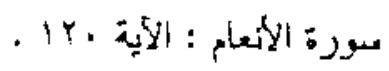




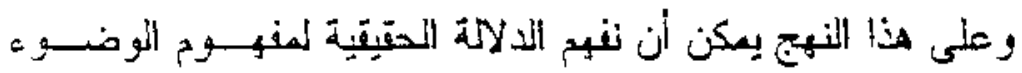
عند المصوفية المسلمين ، فقد صار عندهم بمعنيين : أولمها يتعلق بظـــاهر

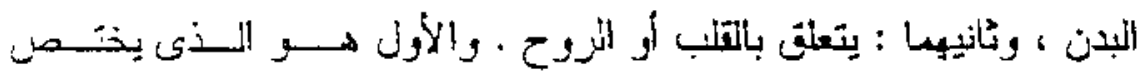

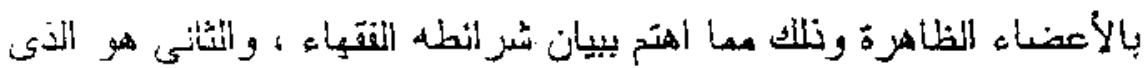

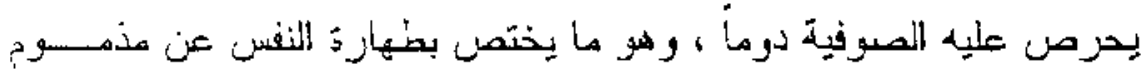

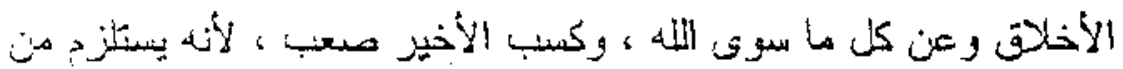

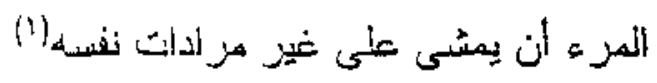

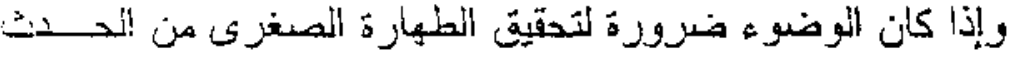

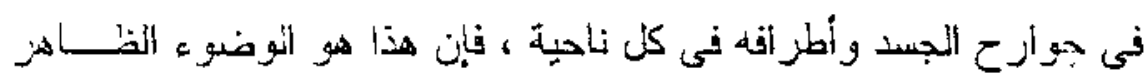

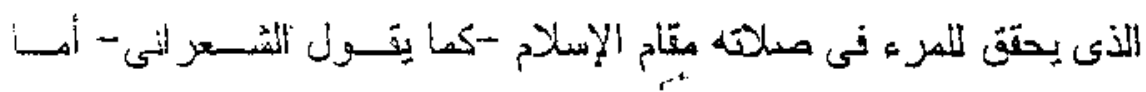

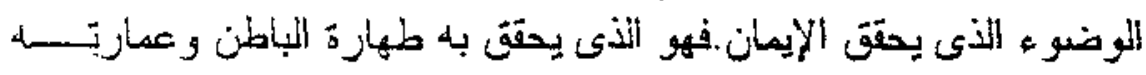

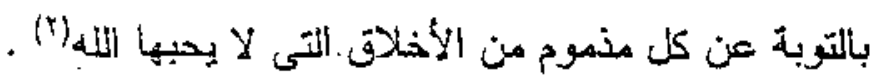

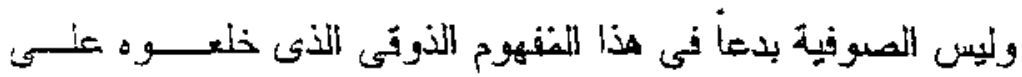

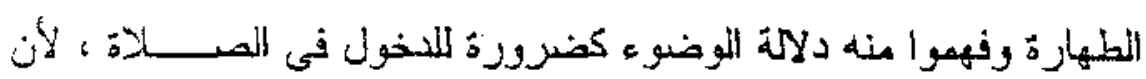

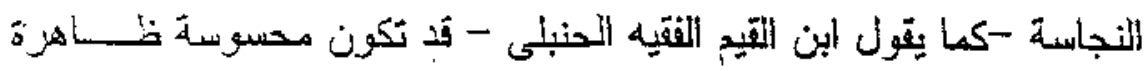

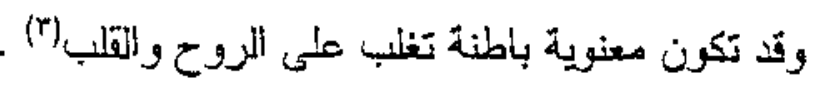

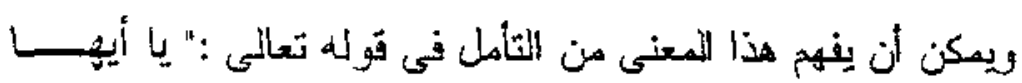

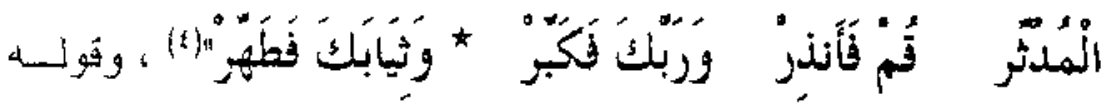

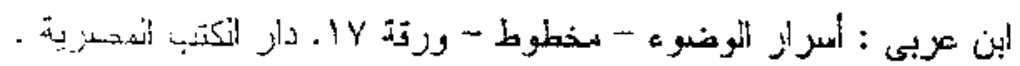

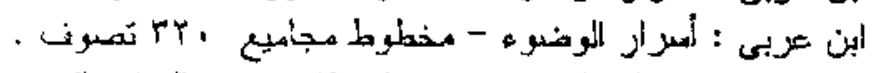

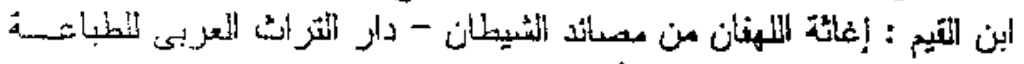

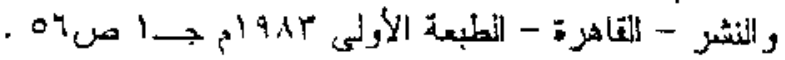

$$
\begin{aligned}
& \text { سورة المدثر : الآيات من الميعة الكاكي }
\end{aligned}
$$




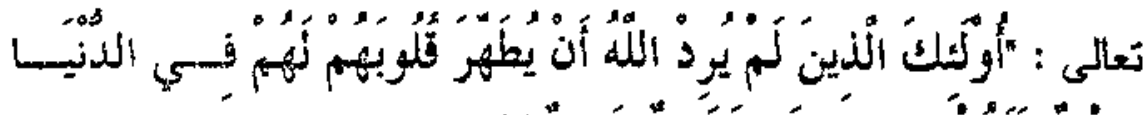

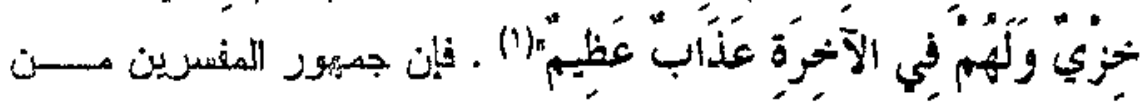

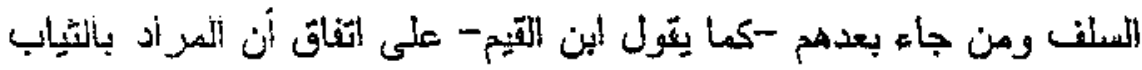

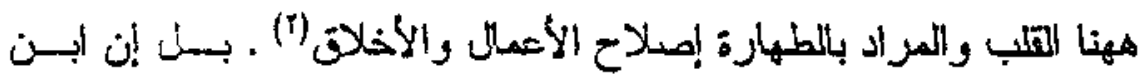

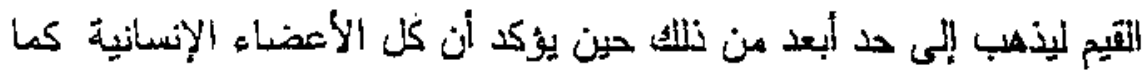

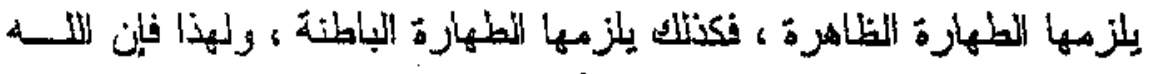

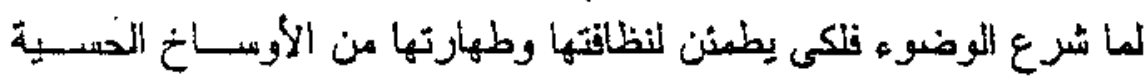

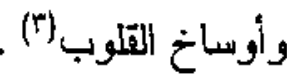

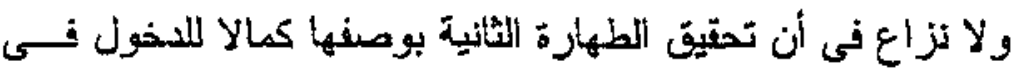

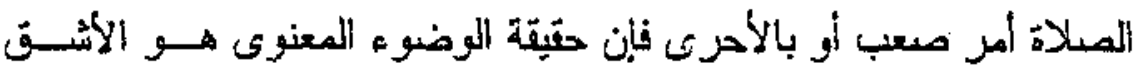

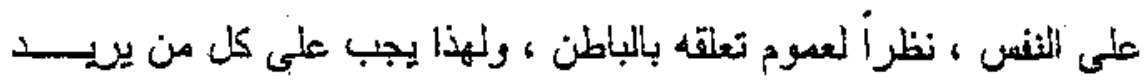

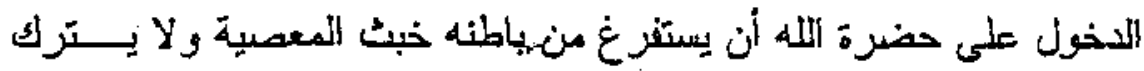

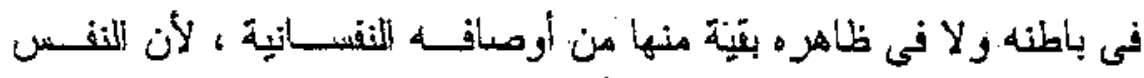

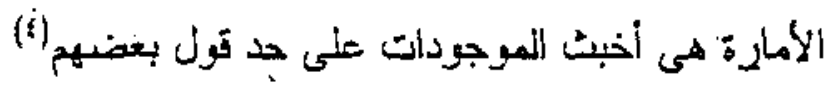

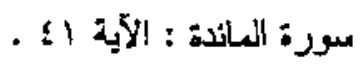

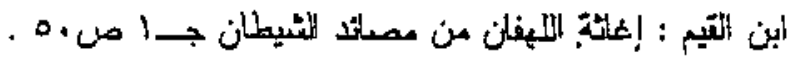

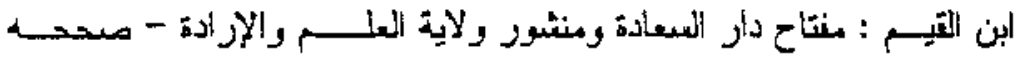

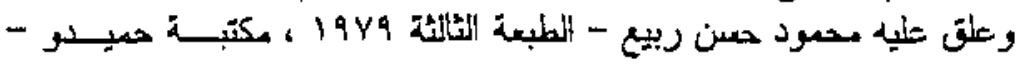

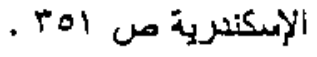

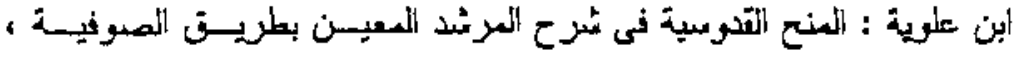

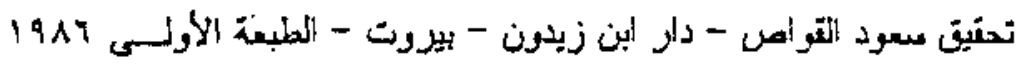




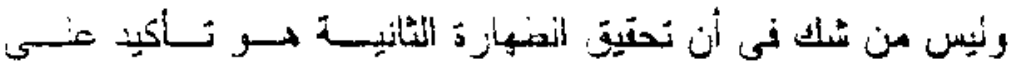

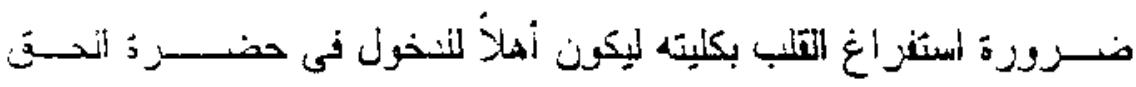

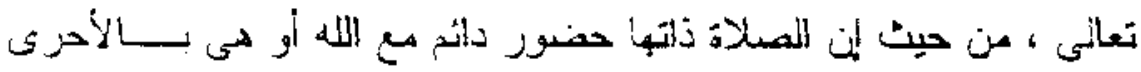

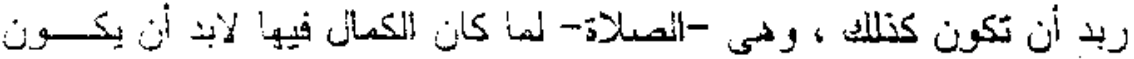

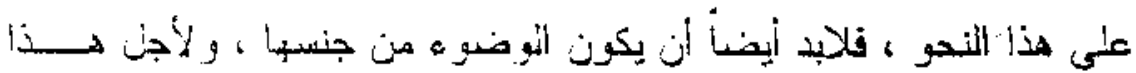

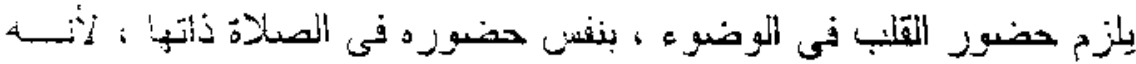

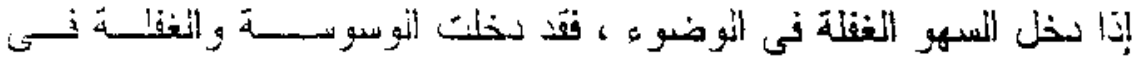

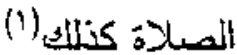

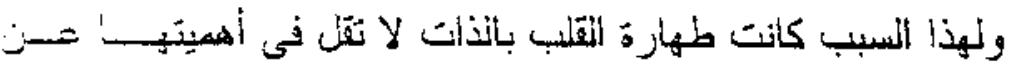

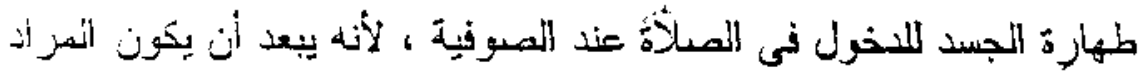

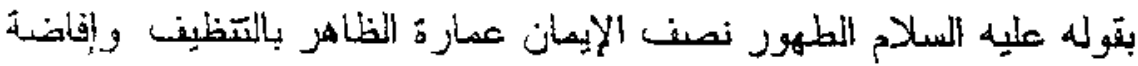

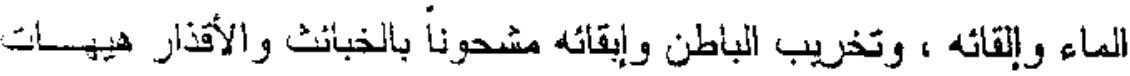

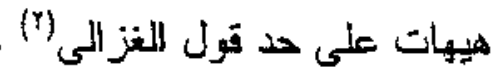

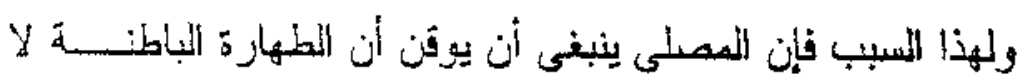

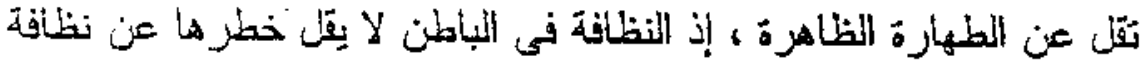

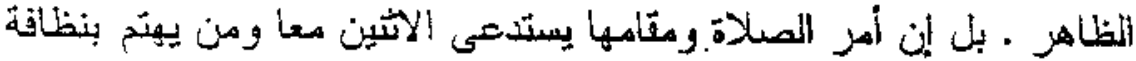

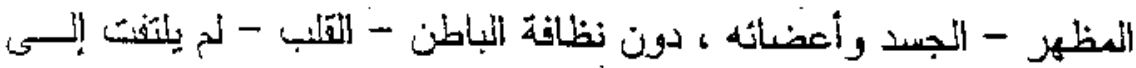

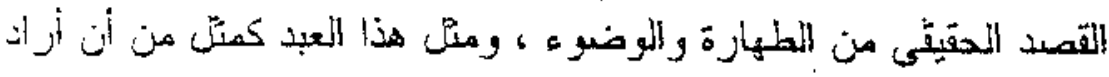

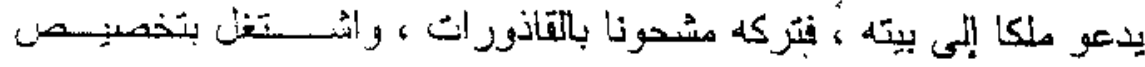

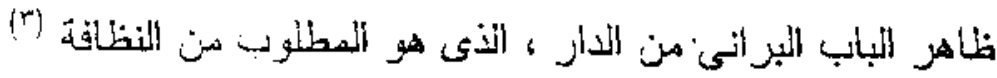

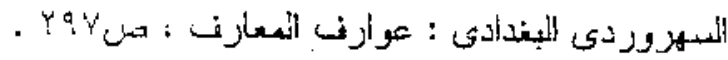

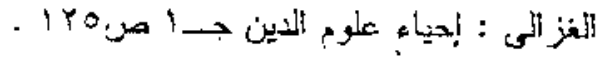

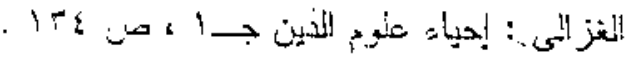




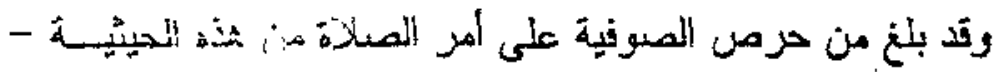

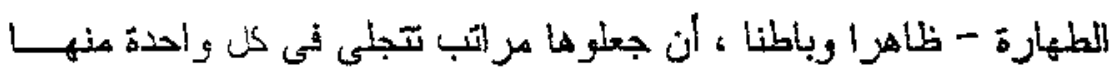

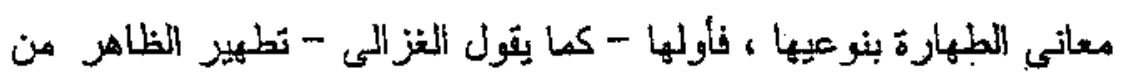

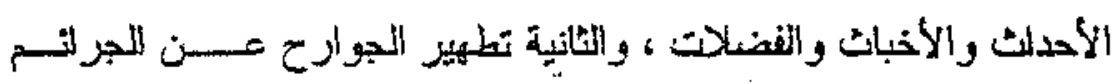

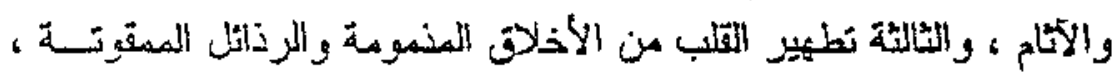

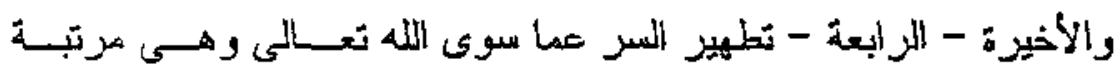

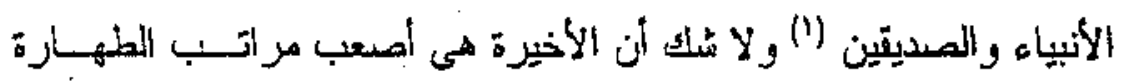

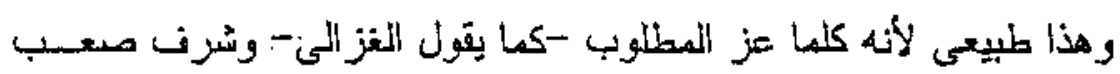

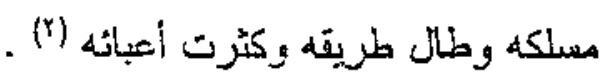

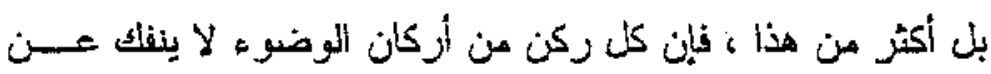

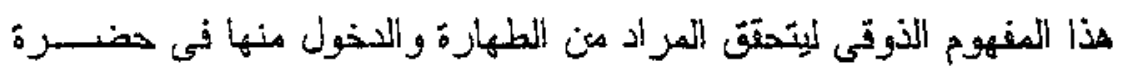

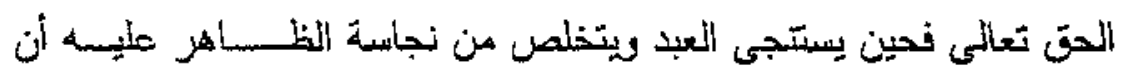

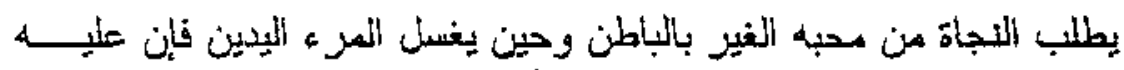

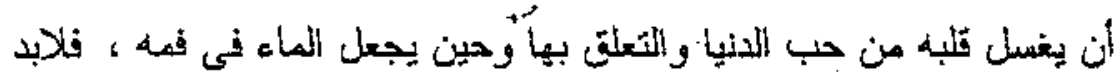

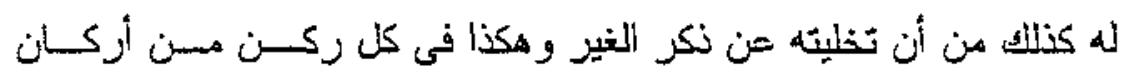

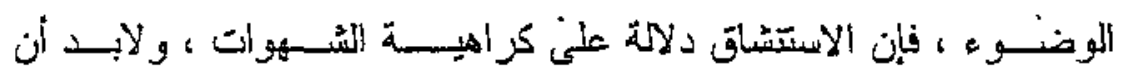

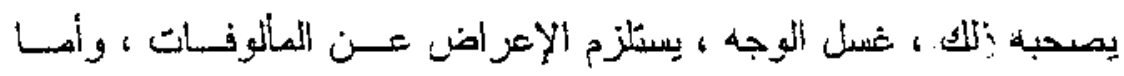

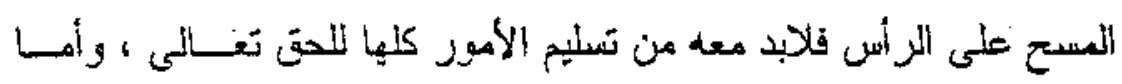

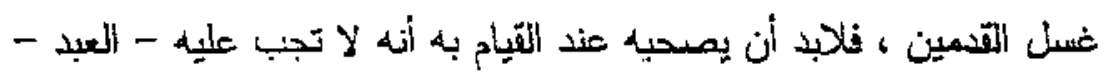

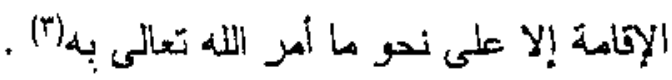

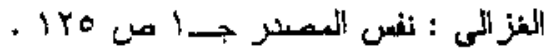

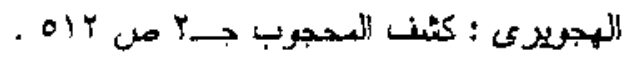

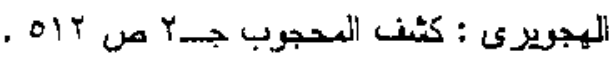


ولميس من نافلة التول أن نوكد فضلا عما أكناه من قبل أن هفهوم

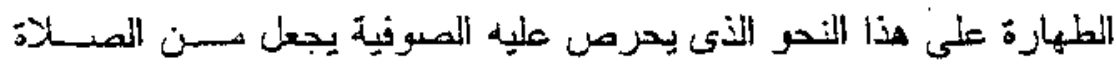

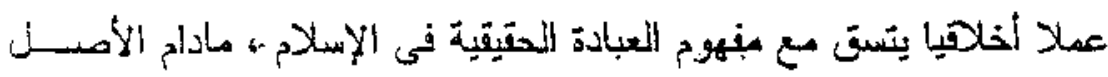

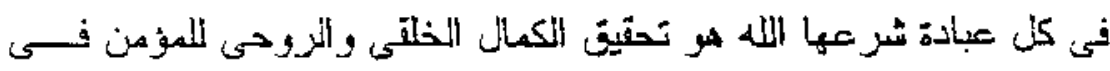

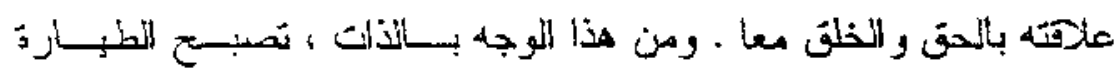

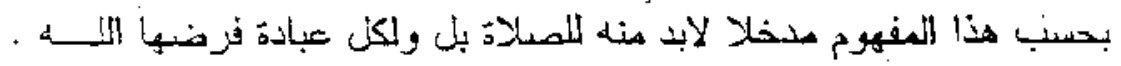

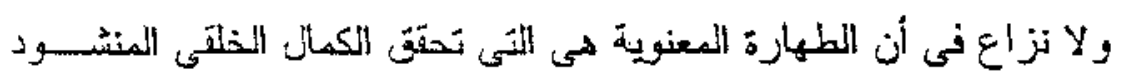

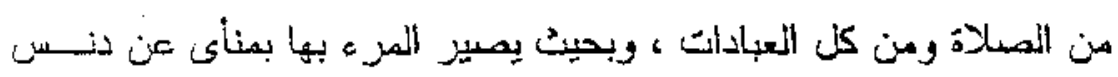

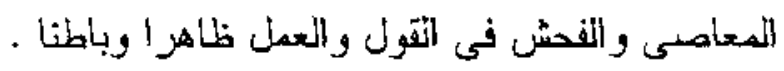
ومن ثم فليس غريبا فئى رأينا- و لا مبالغة فى القول من المسوفية

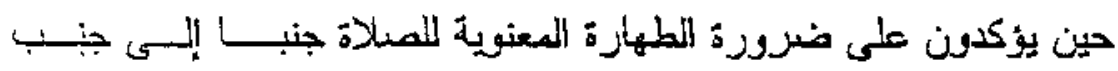

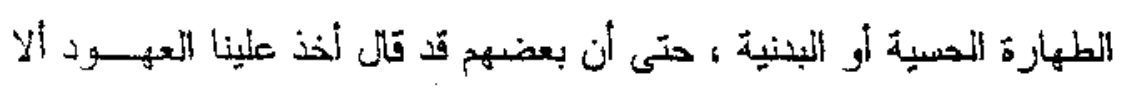

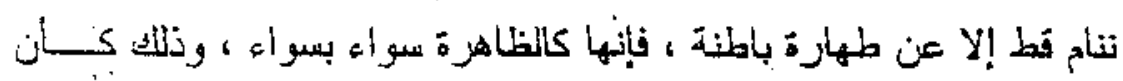

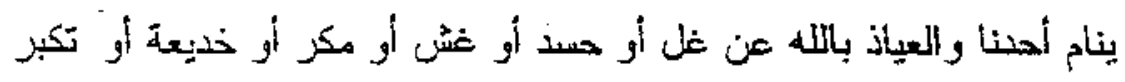

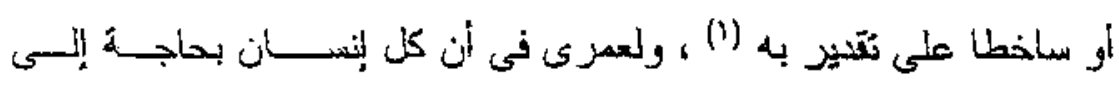

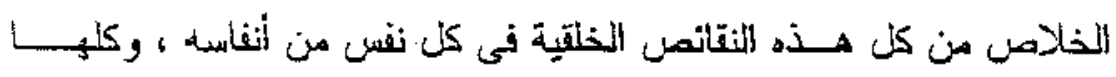

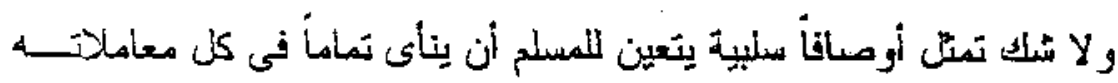

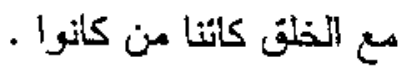

وأول ما يتعين الموقون عليه من أمر المعلاة بعد شرط الطبــــارة

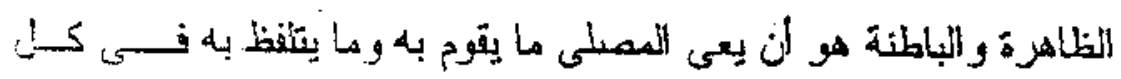

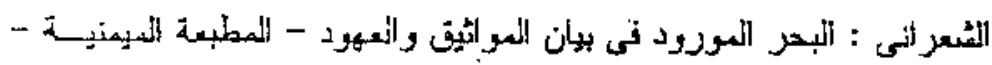

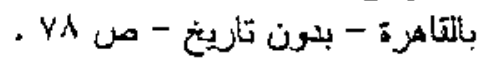




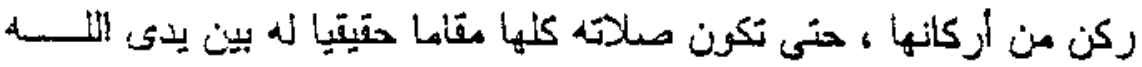

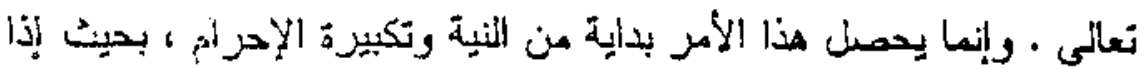

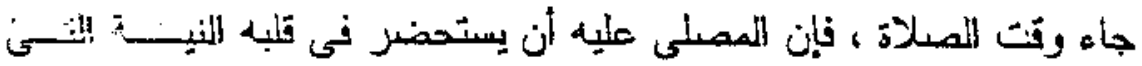
ينوى بها الثترب إلى المله عز وجل ، وإنما يتحقق نلك بإخراج ما في تئبه

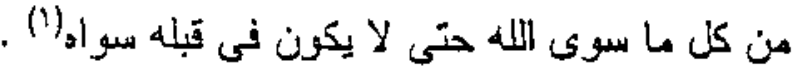

وحضور النية وتحقيقها على هذا النحو ينبغى أن يعيله كل هصنسل

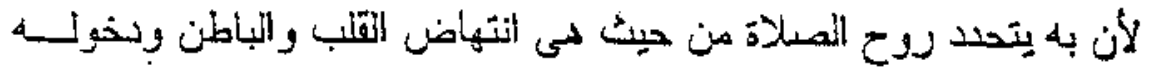

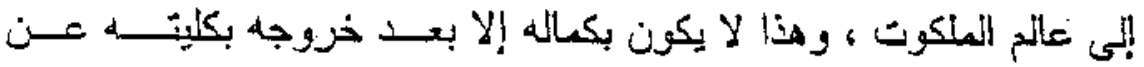

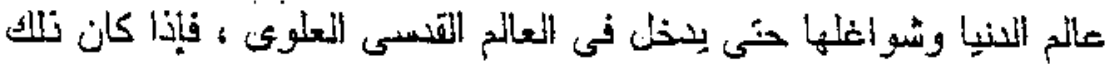

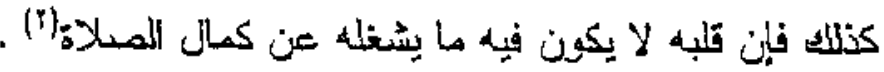

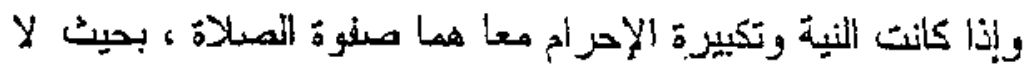

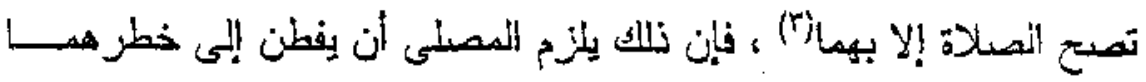

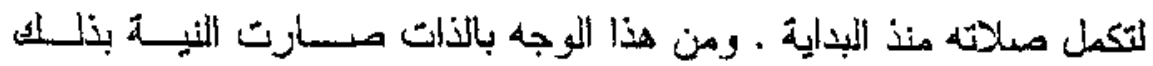

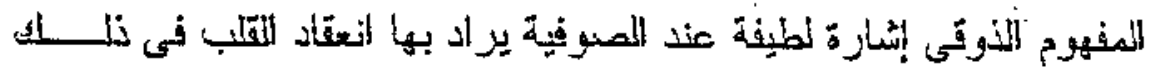

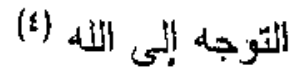

وأصبحت تكبيرة الإحرام هى الأخرى لا نتل في دلالثها الروحية

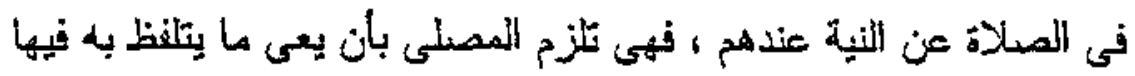

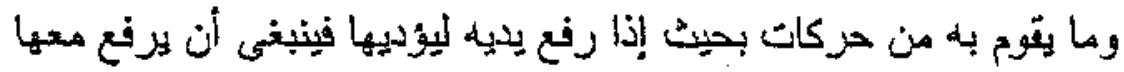

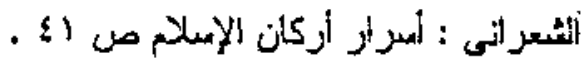

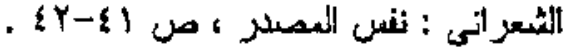

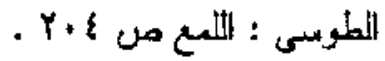

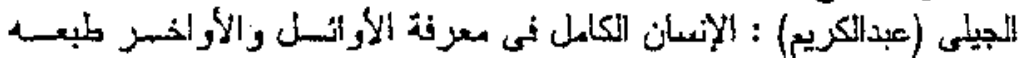

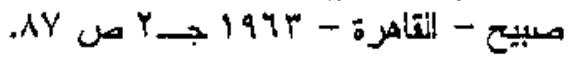




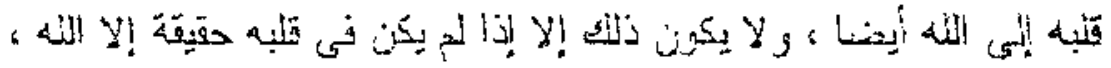

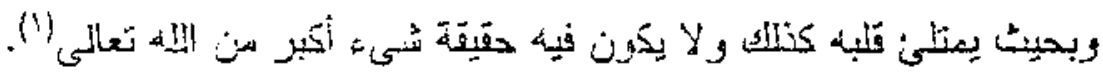

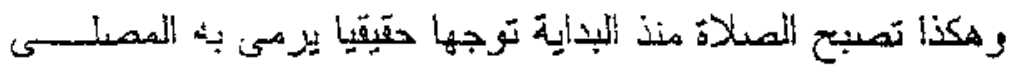

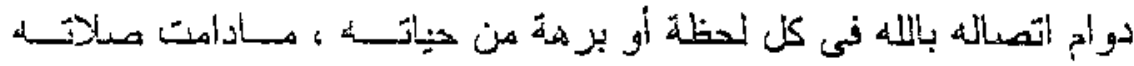

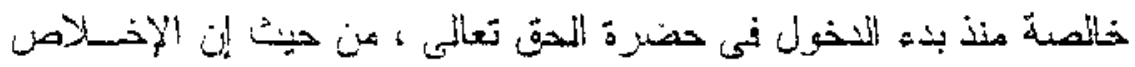

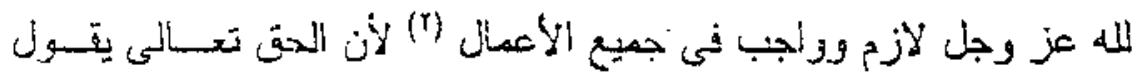

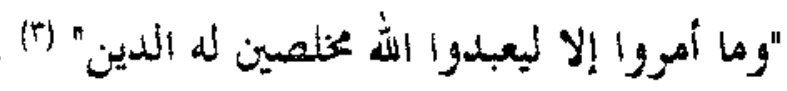

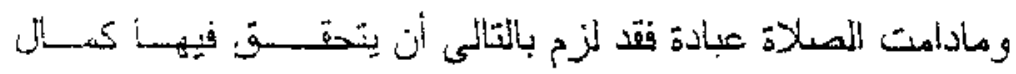
الإخلاص شأنها شان كل عبادة مشروعة يل ثأن كل عمل مأمور نيه مسن

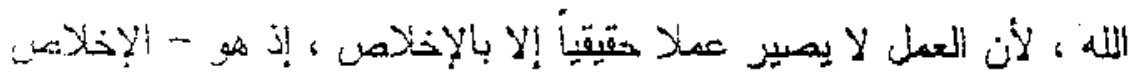

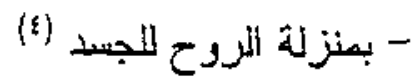

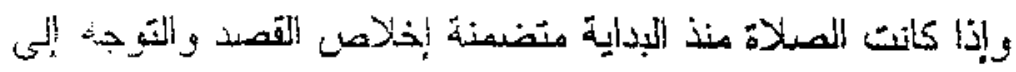

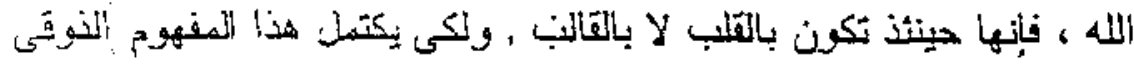

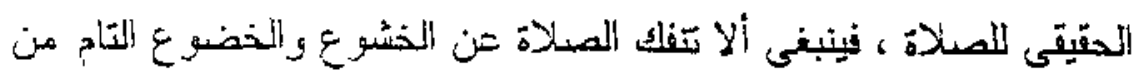

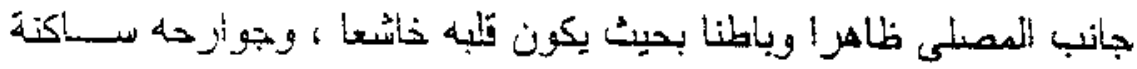

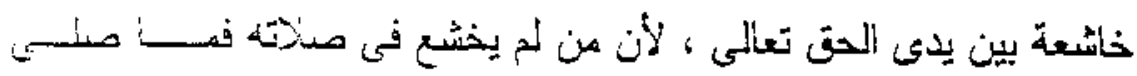

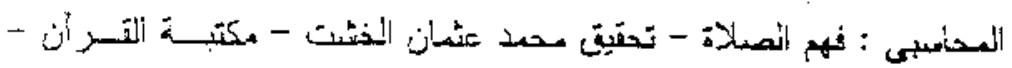

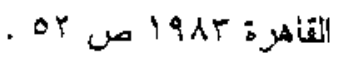

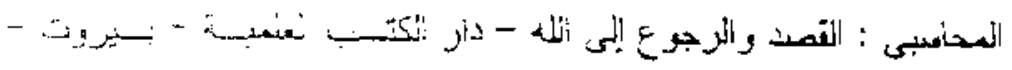

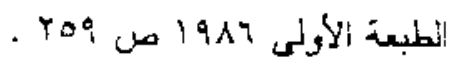

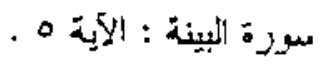

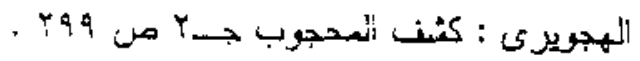




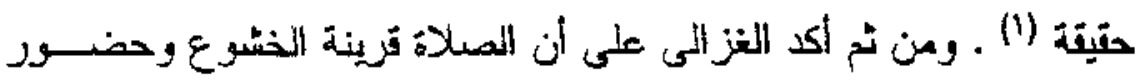
(القلب الن (1)

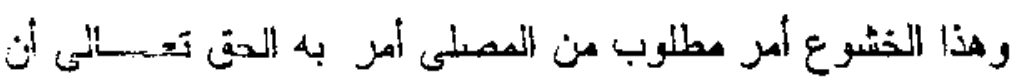

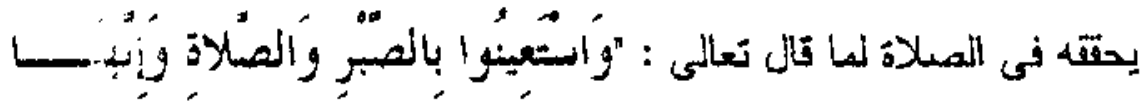

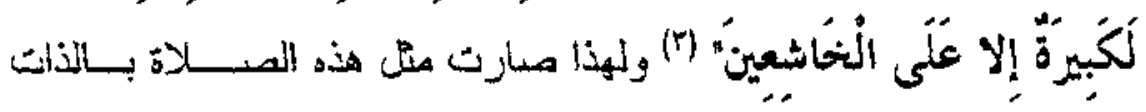

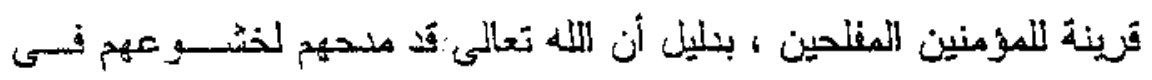

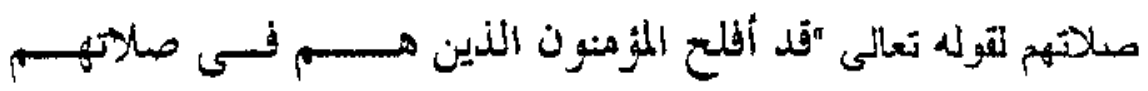

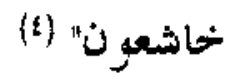

ولا يتاتيى العبد القيام بالصناء على هذا انوجه ، إلا إذا أيقن بكليته

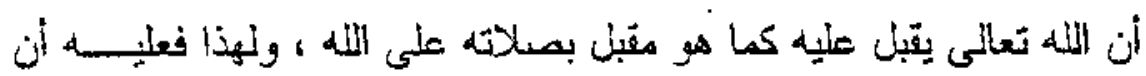

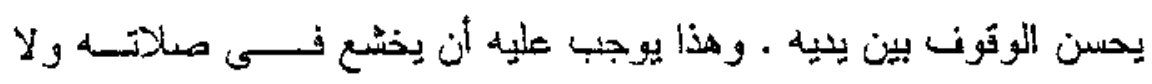

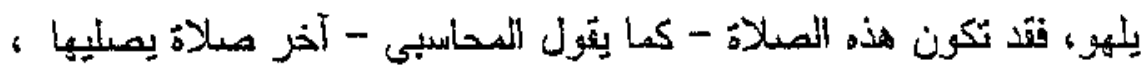

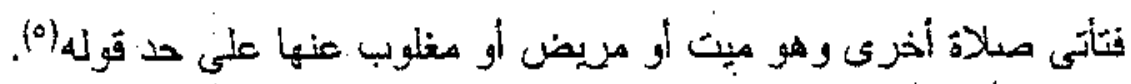

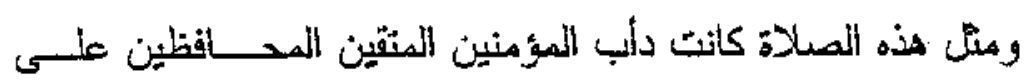

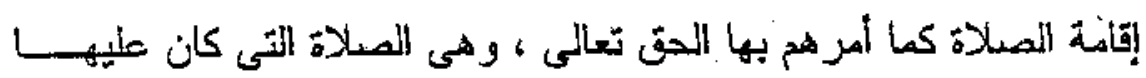

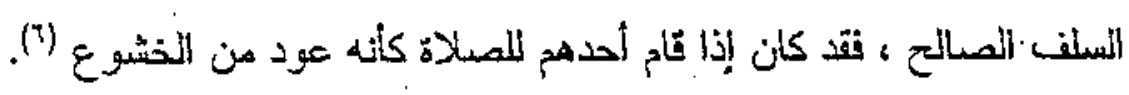

ابن عربم : النتوحات المكية المسنز الثنامن مس 109 ـ .

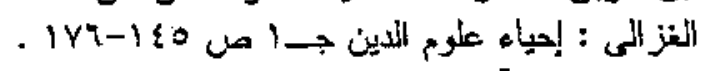

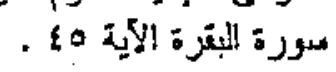

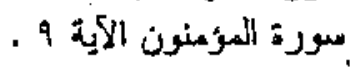

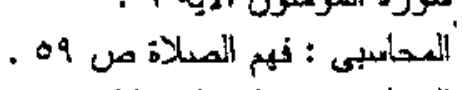

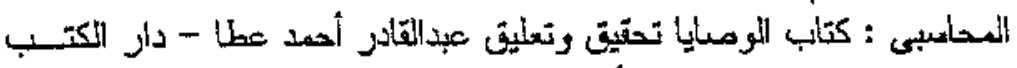




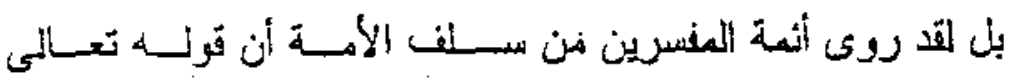

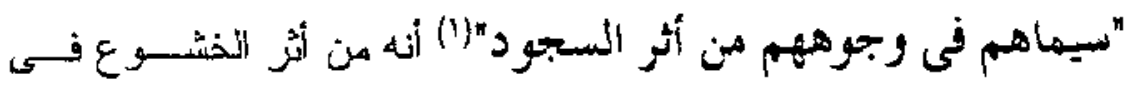

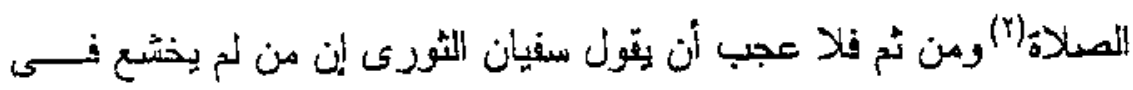
صلالته نقد فسيت صلانه .

وحين تصبح الصدلاة هكذا ختو عا وخضو ما دأتمين من المصلسيى

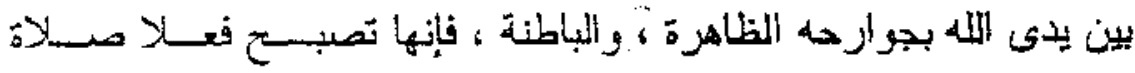

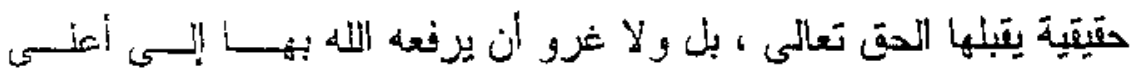
علنين!"

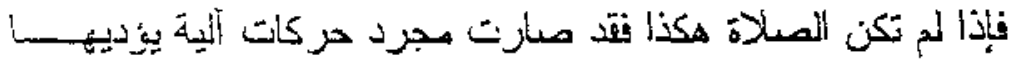

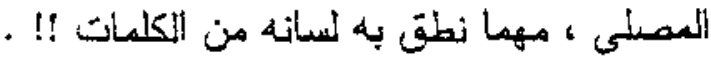

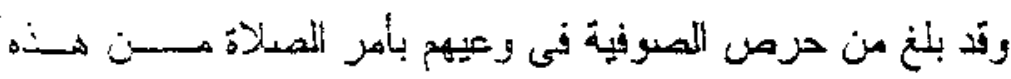

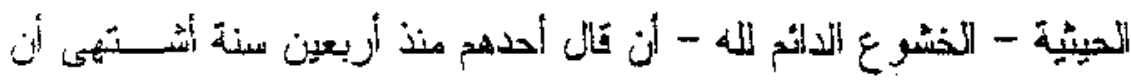

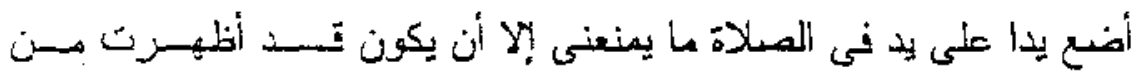

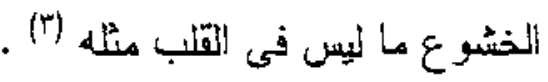
وأظظهر ها يكمن فيه الخشسوع و الإذعان من المصلى في صالخته

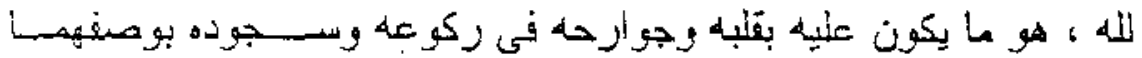

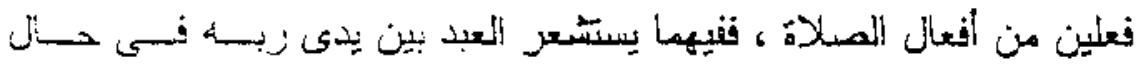

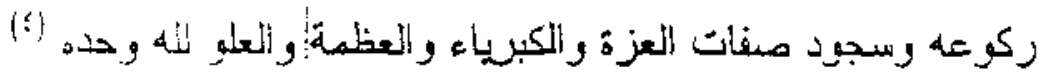

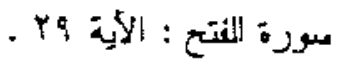

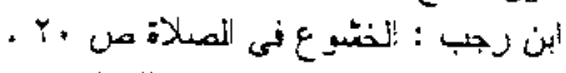

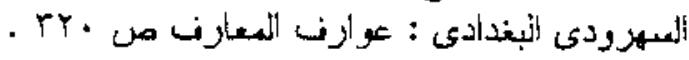

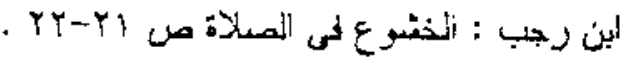




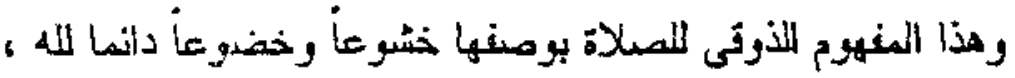

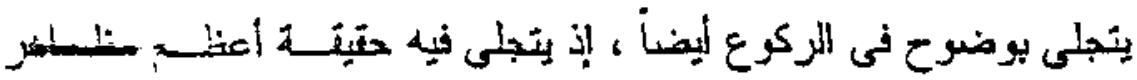

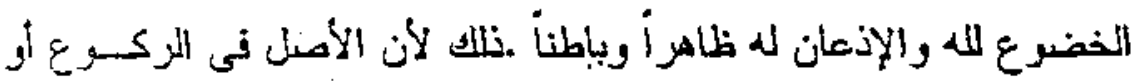
القصد المر أد منه حقيتةة ليس التركوع بالجسد وحده ، وإنما هو كما يقـــول

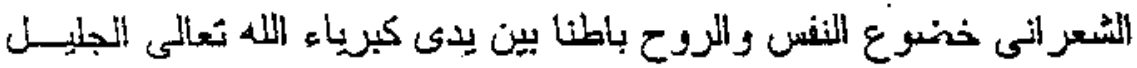

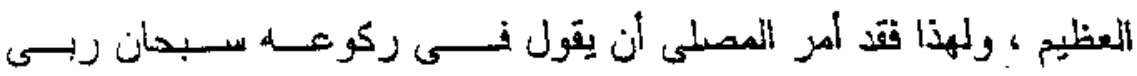
(1)

ولما كان هذا شأن اللركوع في الصهلاة حقيقة ، كان بالتالي ركنسـا

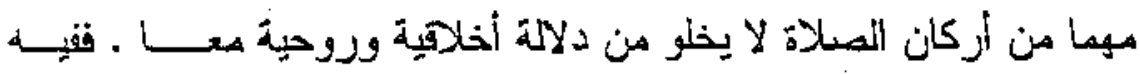

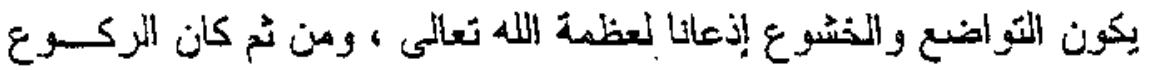

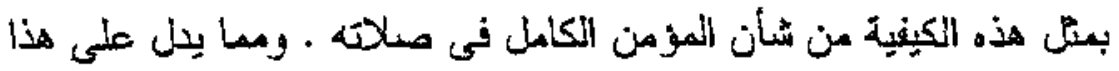

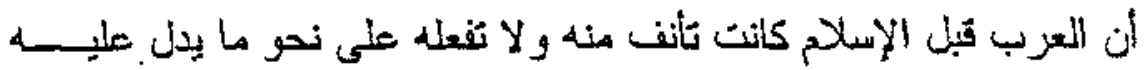

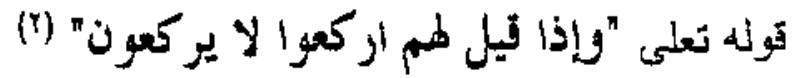

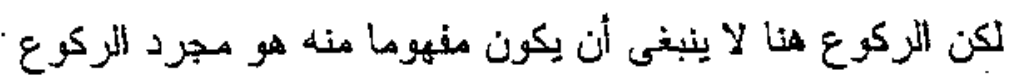

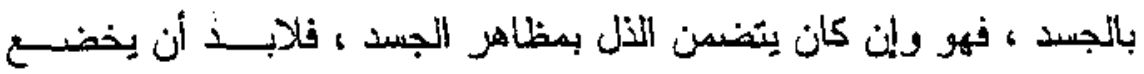

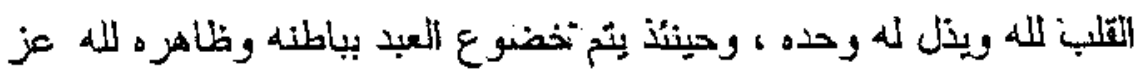
وجل وحده (r) (1)

وتفصيل الأمر فى دلالة الميجود عند المصوفية أو بـــالأحرث مــا

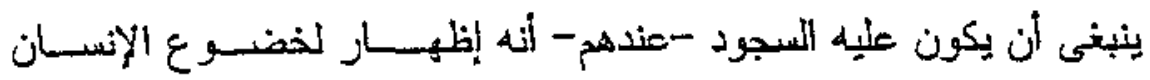

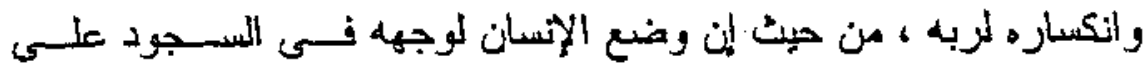

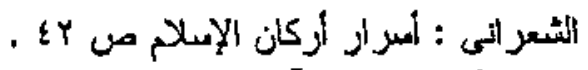

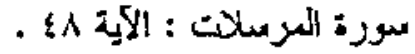

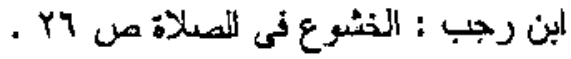


الأرثن يكمن فيه معنى النل والانكسار ، تقىى هذه اللحظة أبضا يشاهد من

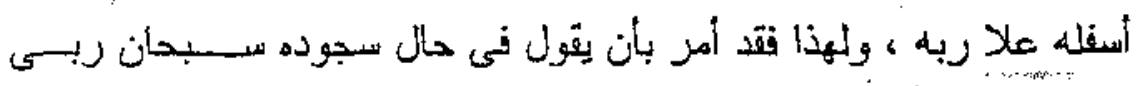

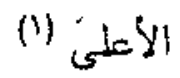

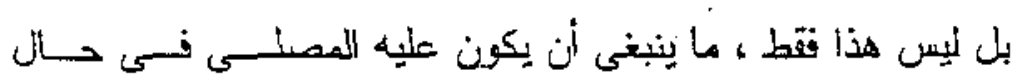

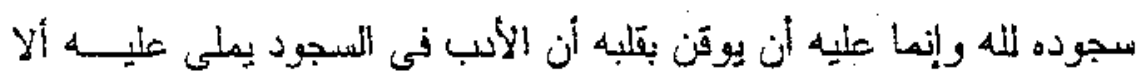

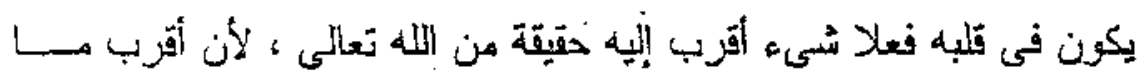

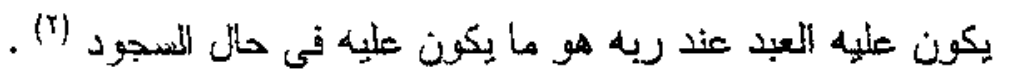
وعله الأمر في دلالة إلسجود على هذا النحو ، هو أن فعل السجبود

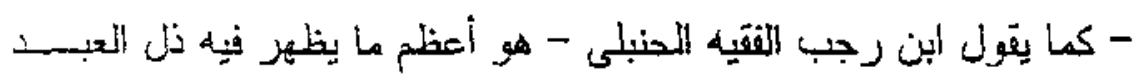

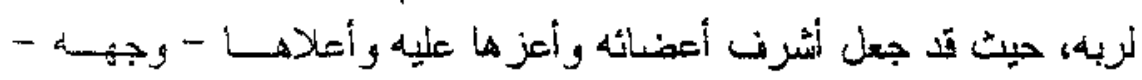

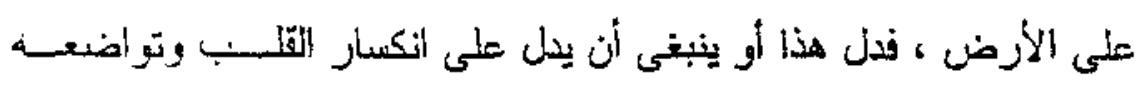

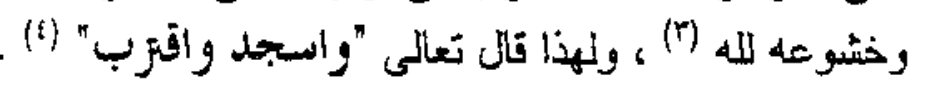

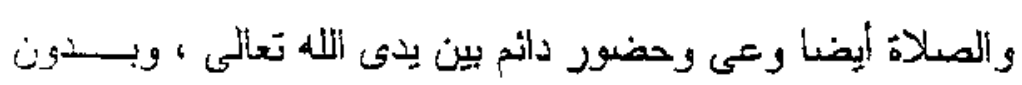

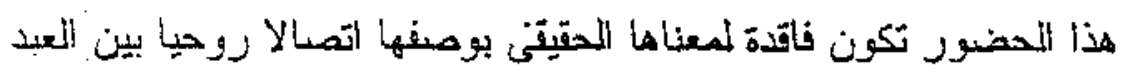

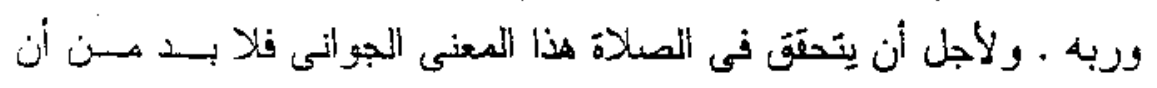

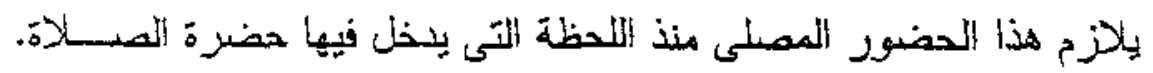

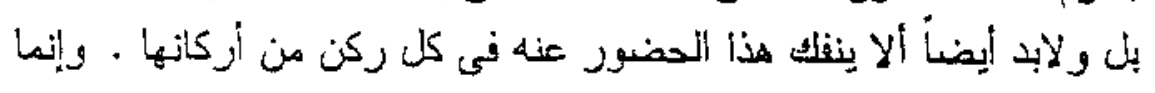

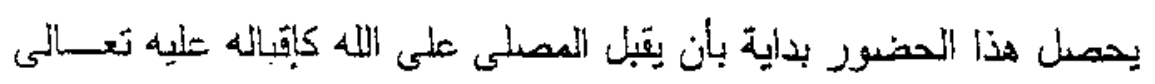

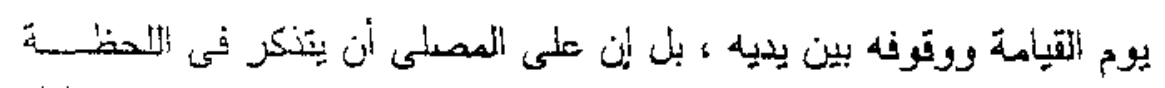

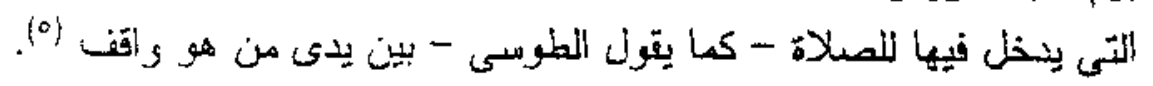

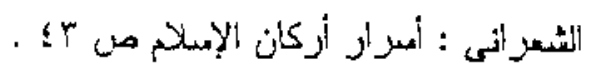

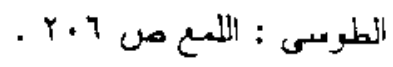

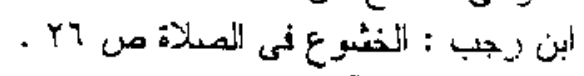

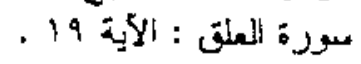

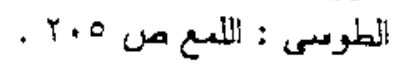




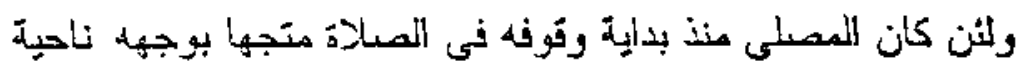

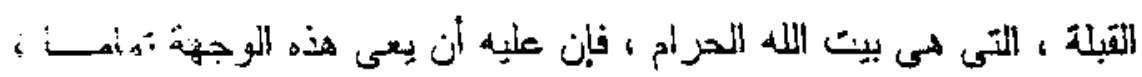

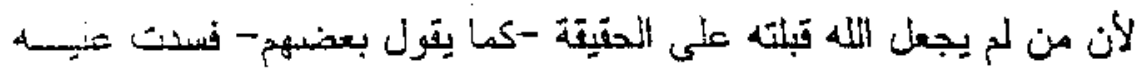
(1) صلاته

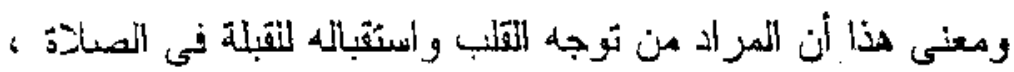

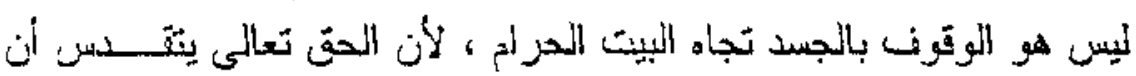

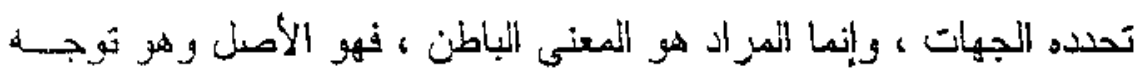

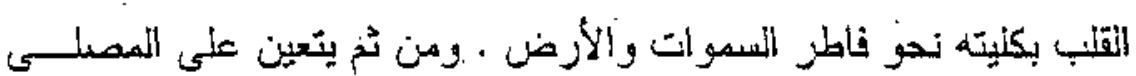

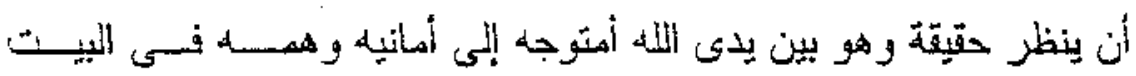

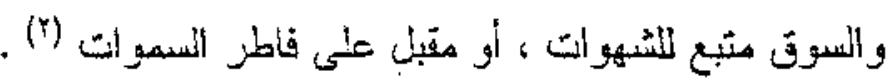
ويمنل هذا الفهم المروحىى المعيق يتحدد المقصود حقا من أســنقبال

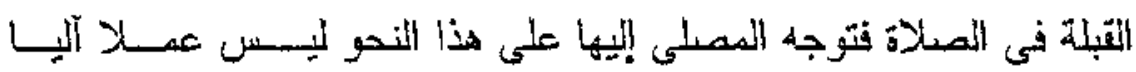

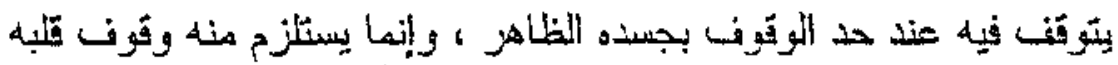

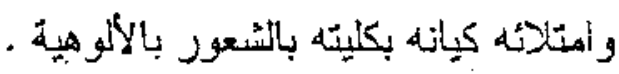

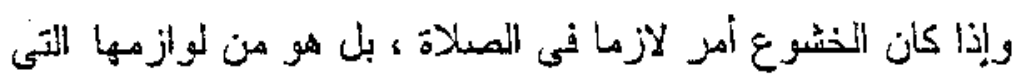

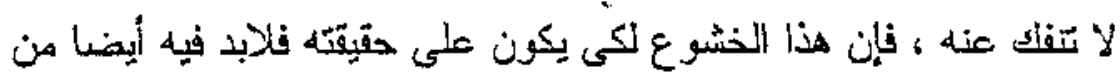

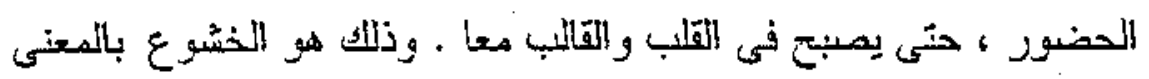

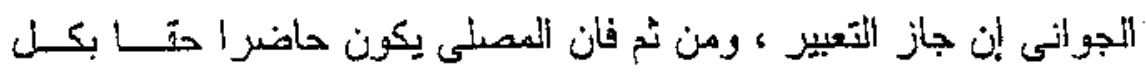

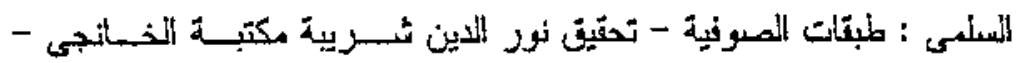

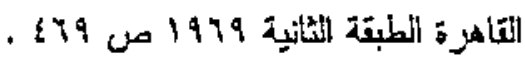

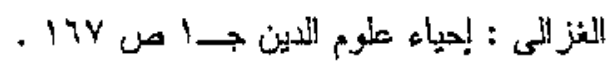




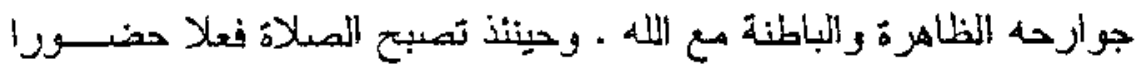

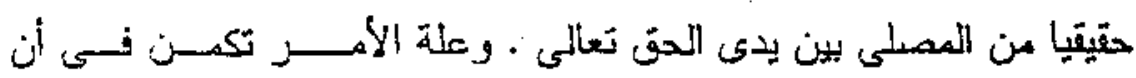

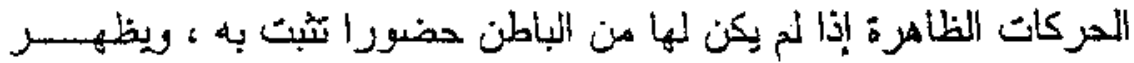

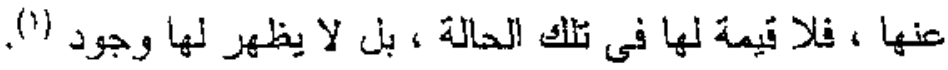

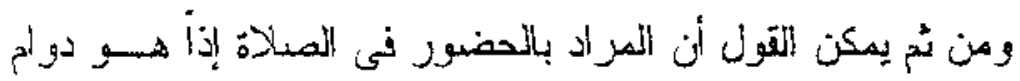

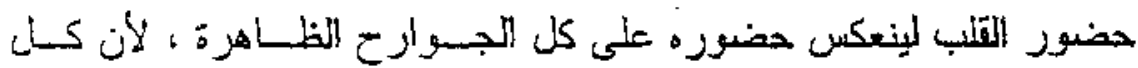

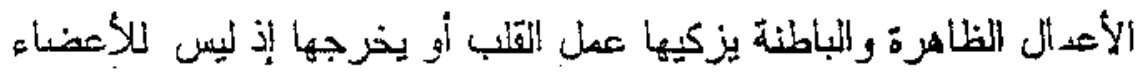

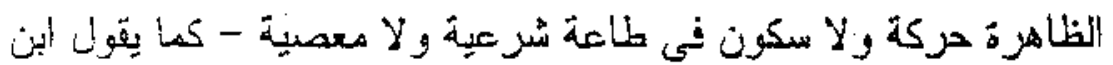

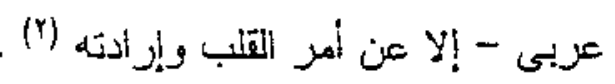

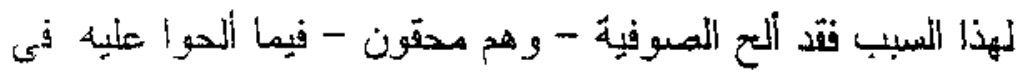

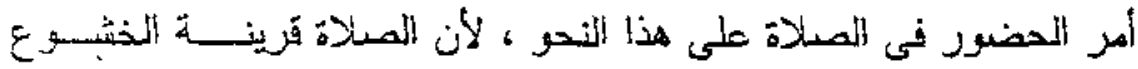
وحضور التقب ، وهى لابد أن تكون كذللك ، واللنيل على هذا - كما يتقون

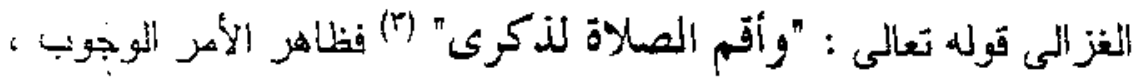
والنغلة تضاد النكر ، ومن ثم فمن غقل فى جميع مدلاته كيف يكون مثنيما (i) للصعلاة

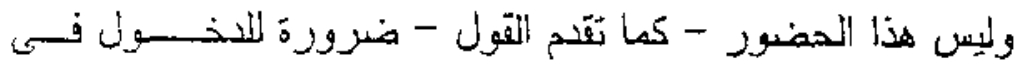
الصلاة فقط ، بل لابد من الحزصل عليه في كل ركن من أركانها إن فنسيى

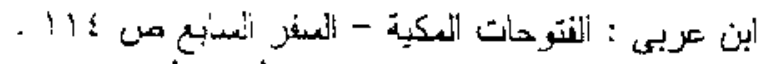

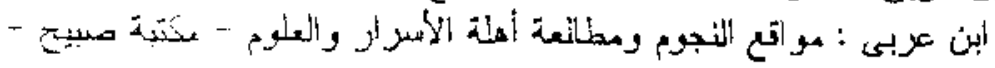

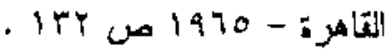

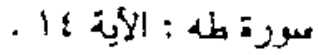

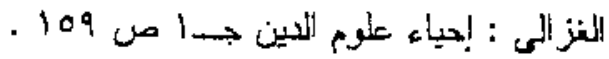




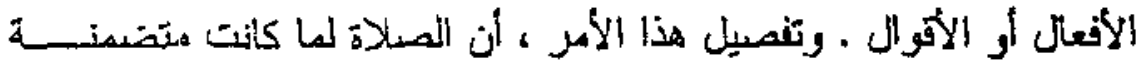

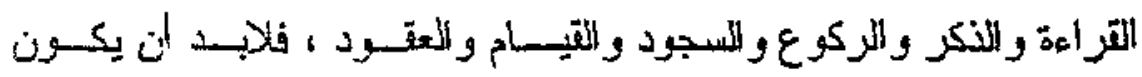
ألحضور في كل هذه الحركات من ناحية ـ ثم هو لابد أن يكون مصأحبـــا

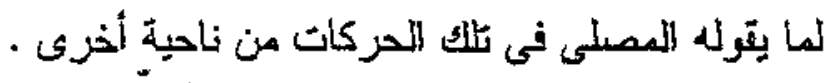

ومن هذا الوجه الأخير فلبن ما ينطلق به المملى هن كلام لابد فيه

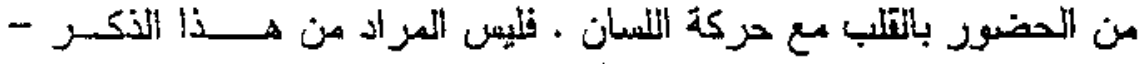

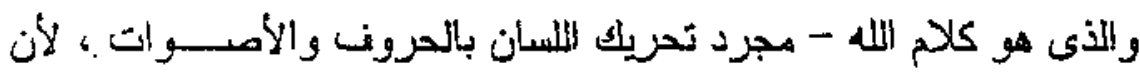

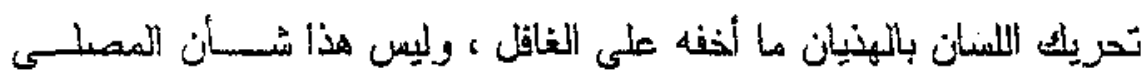

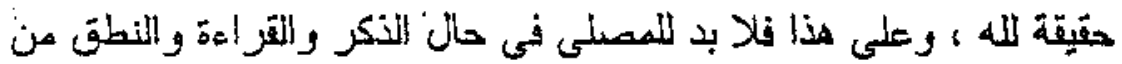

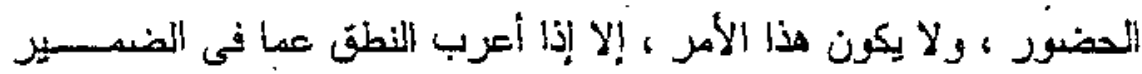

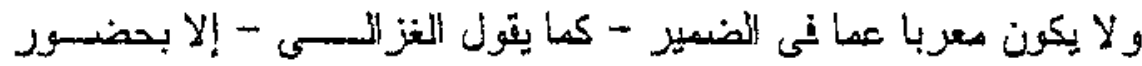
(1) الإتنب

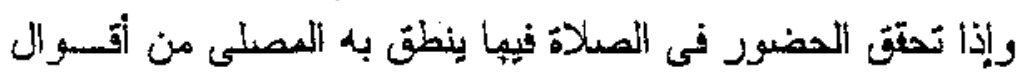

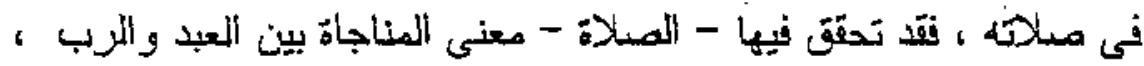

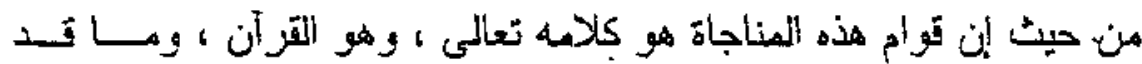

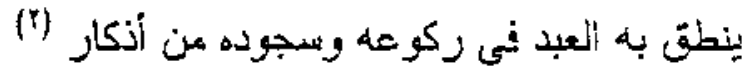
ومأدام الآمر هكذا ، فيتعين إذأ على الميطلى أن يعى ها ينطق به ليه

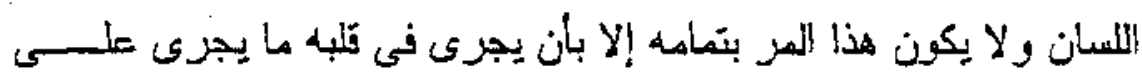

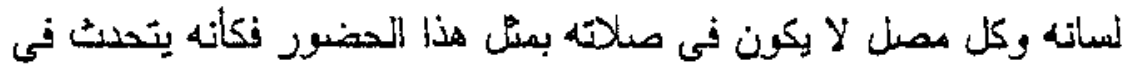

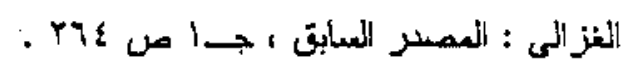

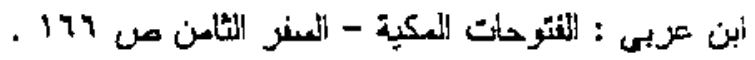




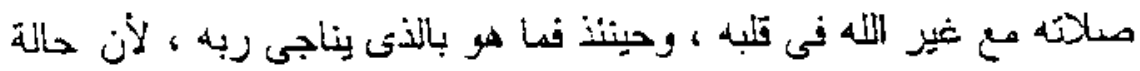

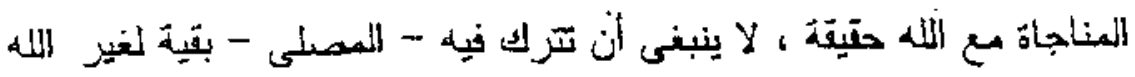

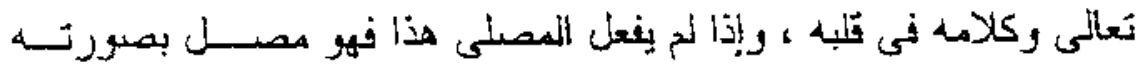

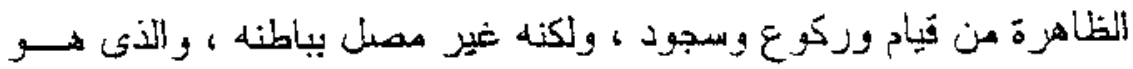

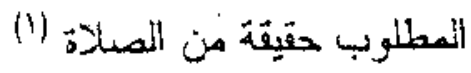

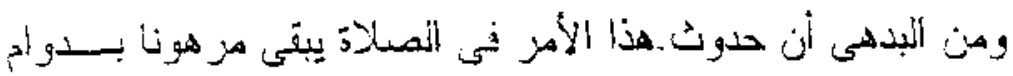

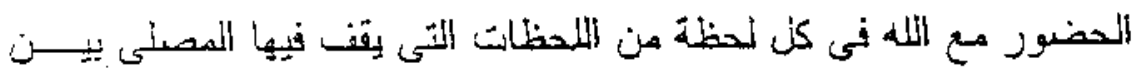

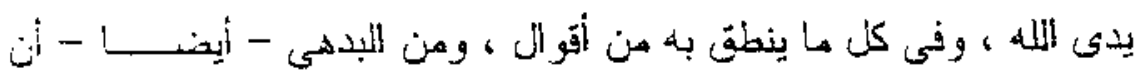

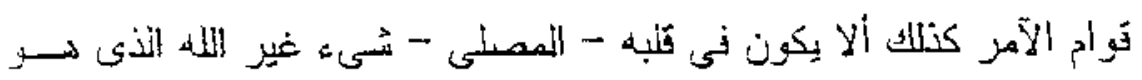

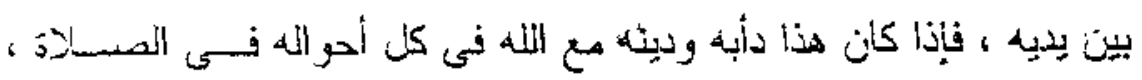

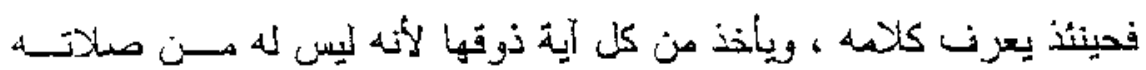

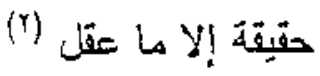

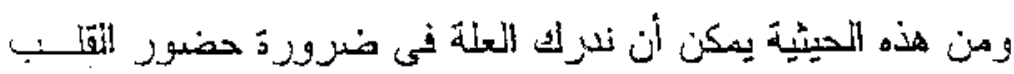

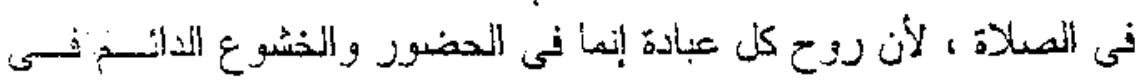

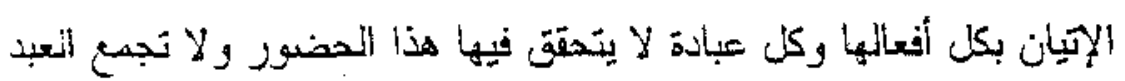

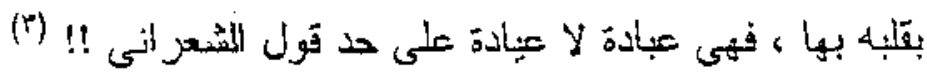

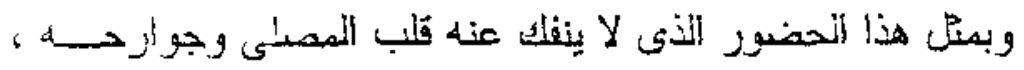

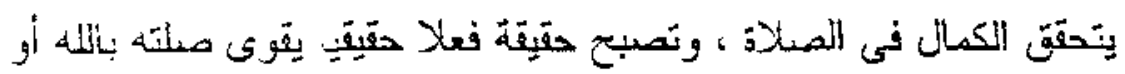

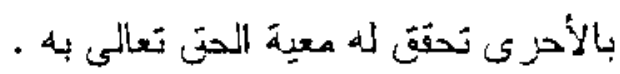

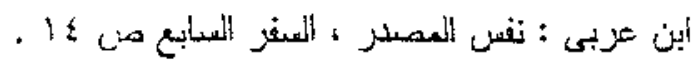

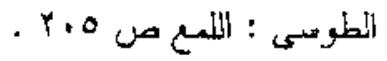




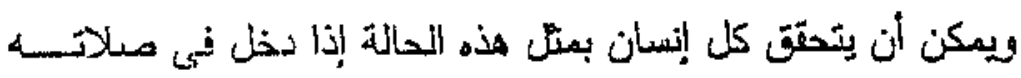

وحرمل على إقامنها بهذه المكيفية ولا بتأتى هذا بطبيعة الحالة إلا إذا لـسمح

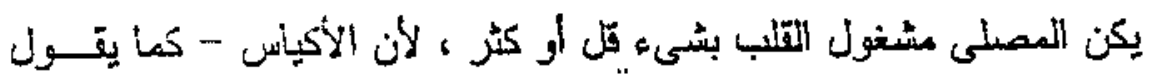
السهروديى البندادي - لم يرفضوا اللدنيا إلا ليقيموا المصلاة كما أمـــروا .

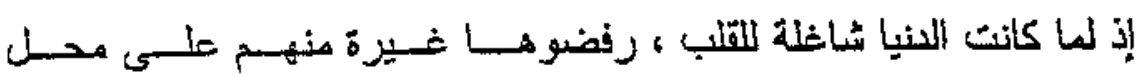
(1) (1)

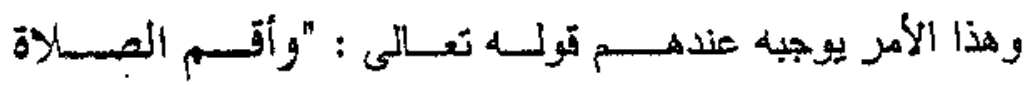

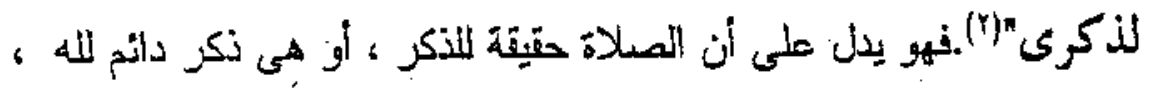
فإذا كان هذا هو شأن المصلاة فكينس يقع فيها النسيلن (r) ولهذا إيضا كمسان

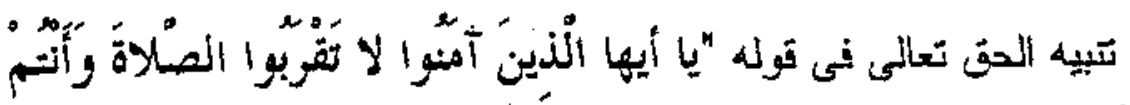

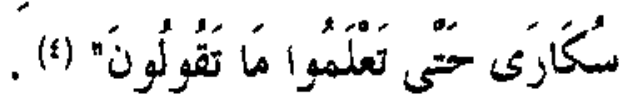

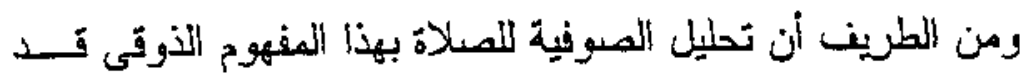

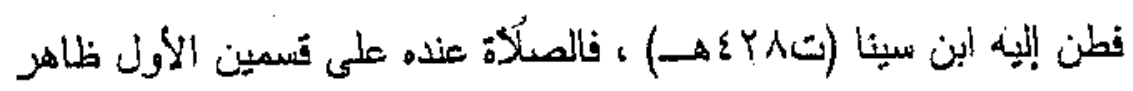

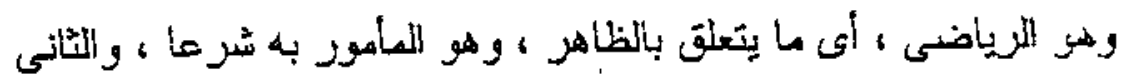

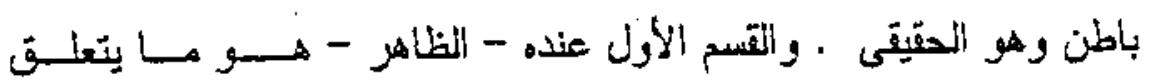
بحركات الصلحة وأفعالها ، وركن المثاني -الباطن -هو مأهية المصلاة أو هو القصد الحتيقى هنها ، بوصفها اتصالا ومناجاة لله و هر الأمر إلذى جعـل

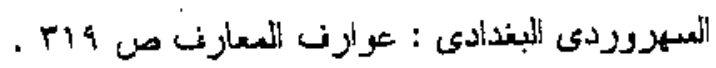

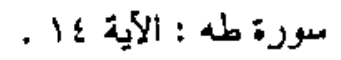

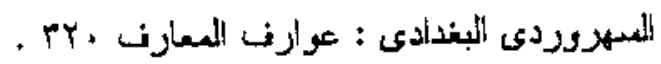




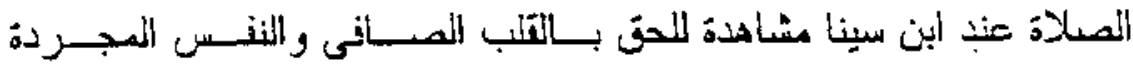

(1) المطبرة عن الأهانيى

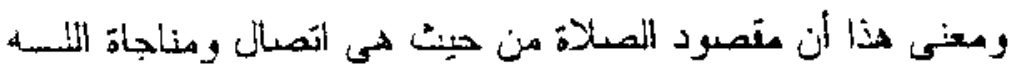

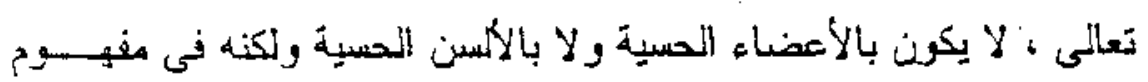

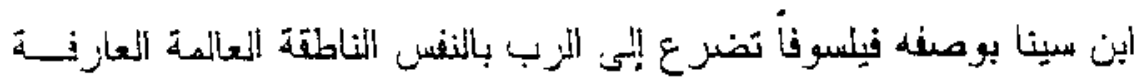

(1) بوحذأنية المحق تعاللى

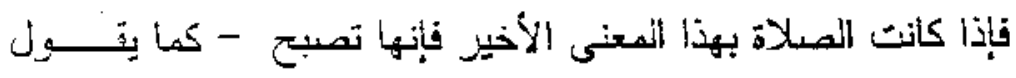

أبن عينا- هي المشاهدة المزبانية ، و التعبد المحضن الذّى هو المحبية الالنهية

و المزئية المروحانية

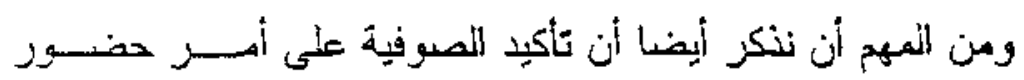

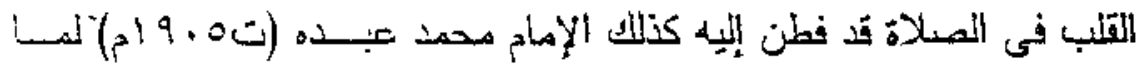

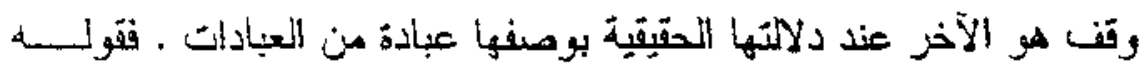

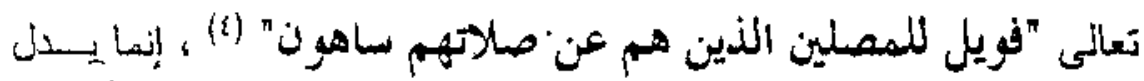

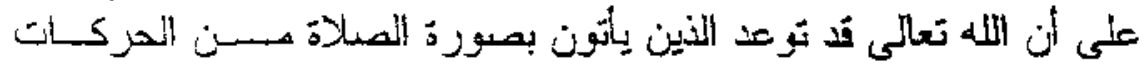

رالألفاظ مي المسهو عن معنى المعبادة فيها ، وسرها المؤدي إلى غايتها (0).

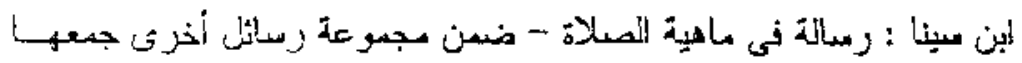

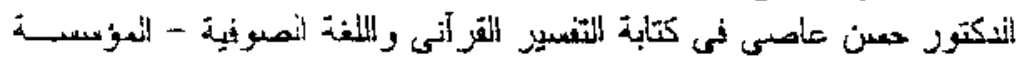

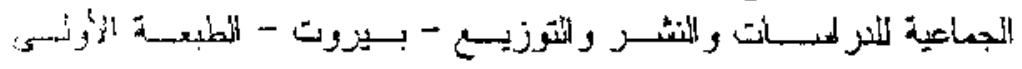

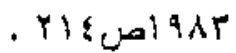

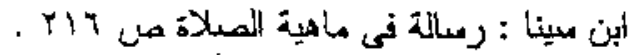

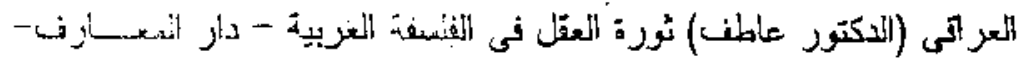

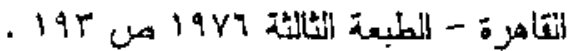

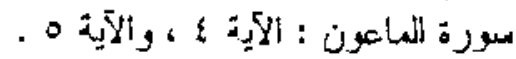

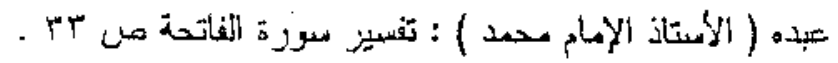




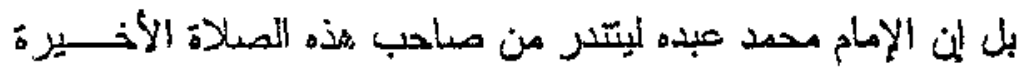

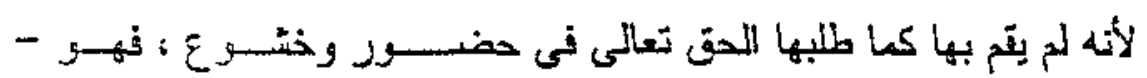

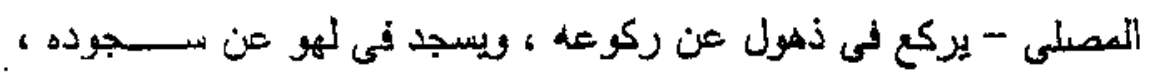

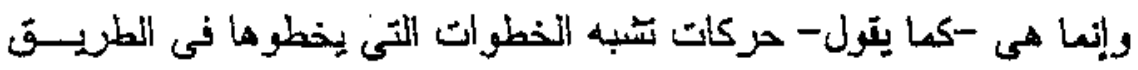

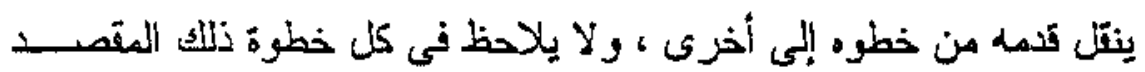
الذي تصده بمشية (1)

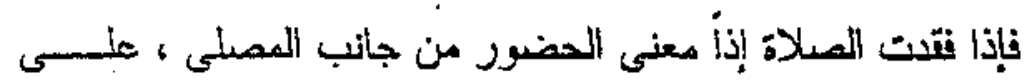

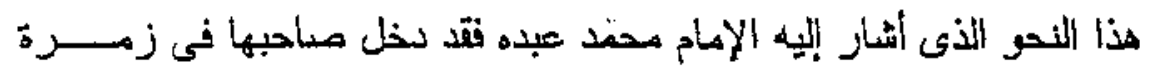

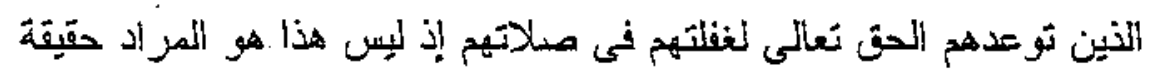

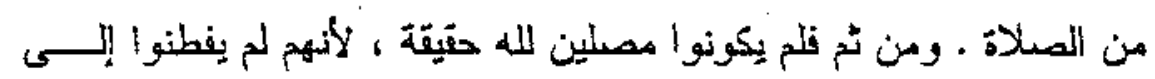

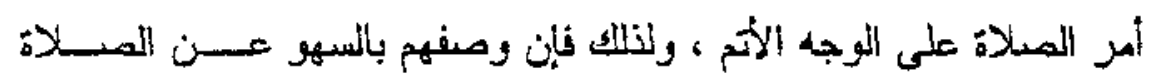

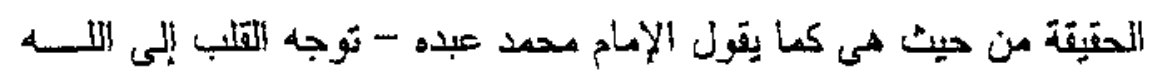

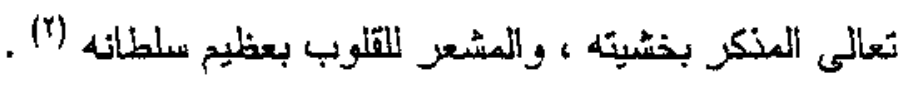

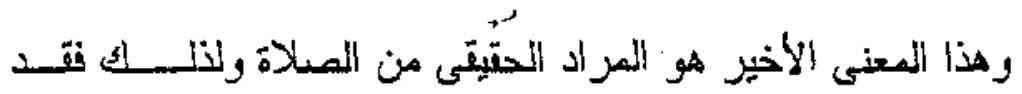

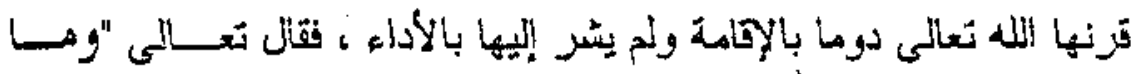

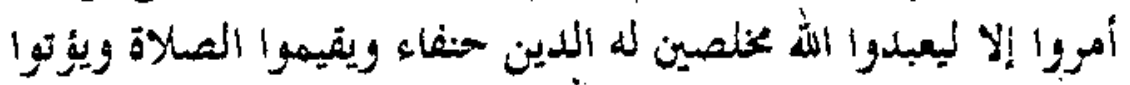

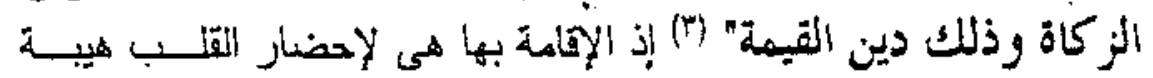

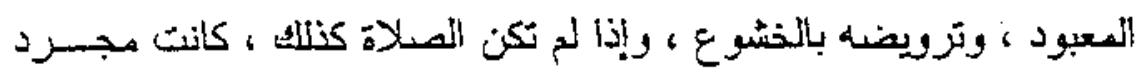

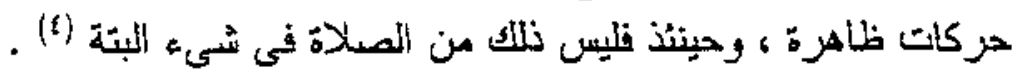

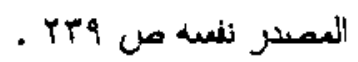

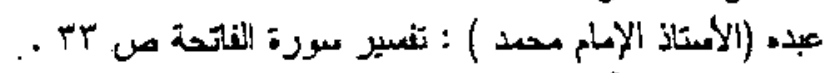

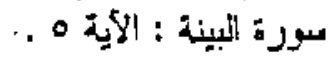

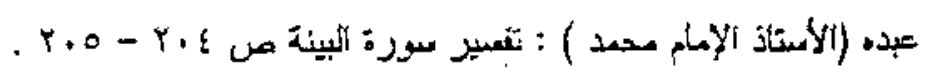




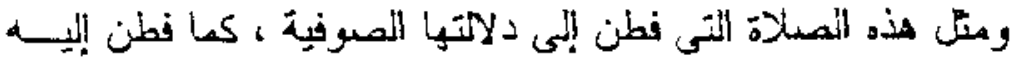

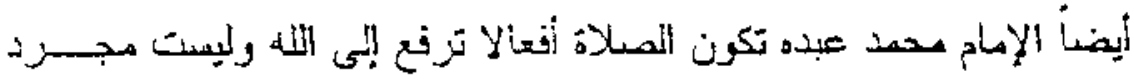

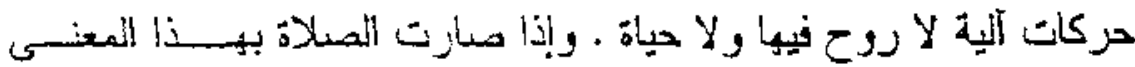

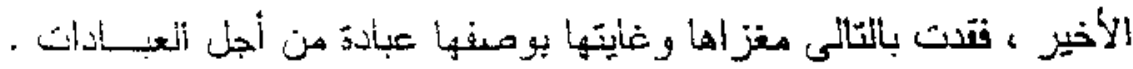

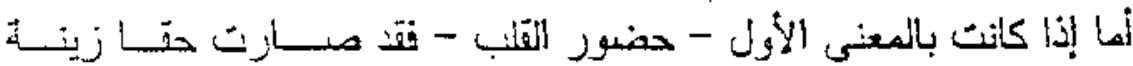

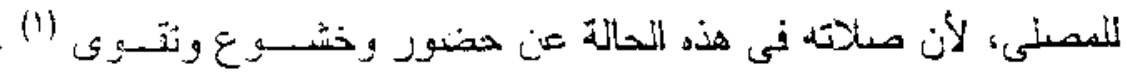

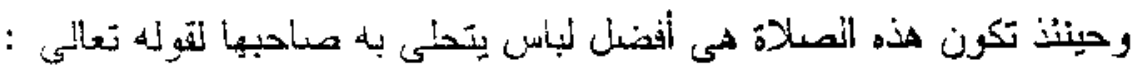

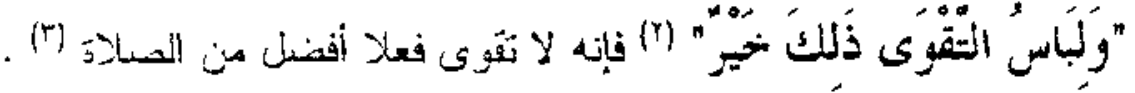

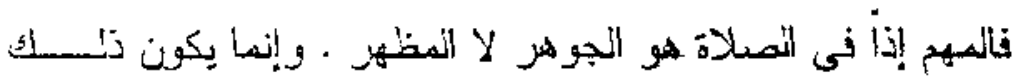

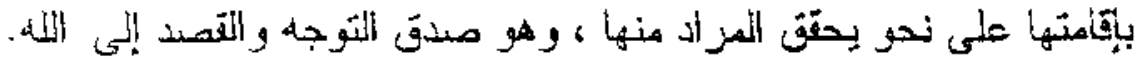

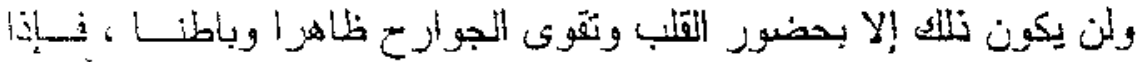

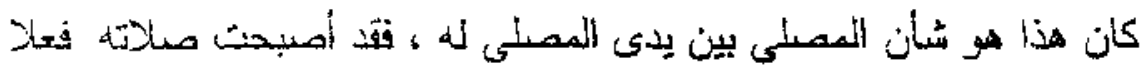

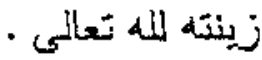

وإذا كان المحق تعالمي قد أهرنا بالتزين عند ألذهابب إلمسىى النهنسمجد

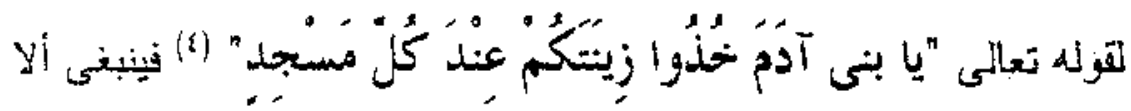

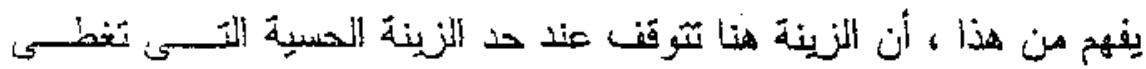

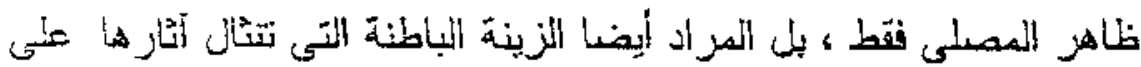

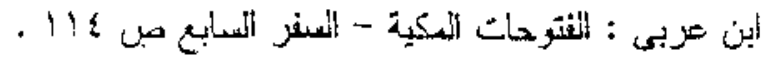

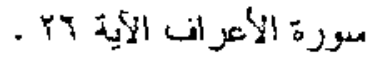

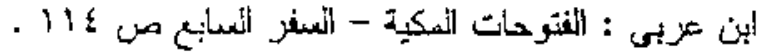

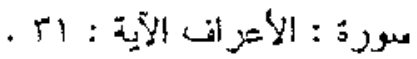




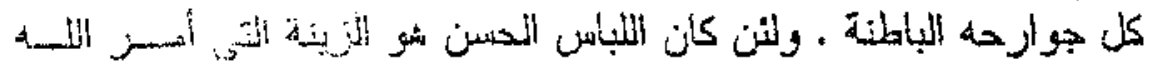

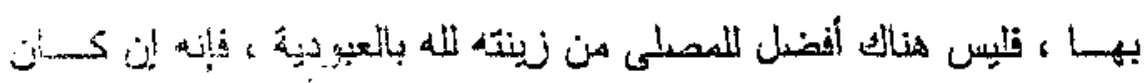

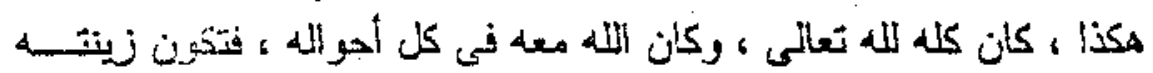

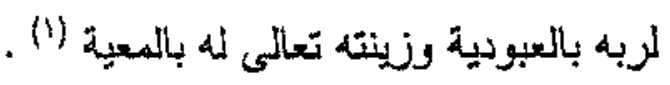

وعلى هذا يمكن القول أن المـلاة كما تحقــق لصاحبهـــا أخـلاق الصنق والتواضع والخشية والهيبية والأبب مع الحق والمخلق ، فلإنها أيضاً

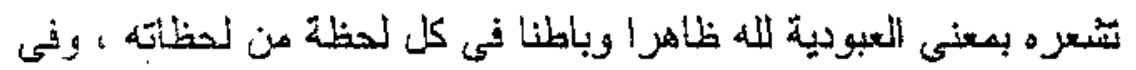
الشععزر بالعبودية -فى رأينا- ببطن معنى الحرية كذلك بالمعنى المروحي.

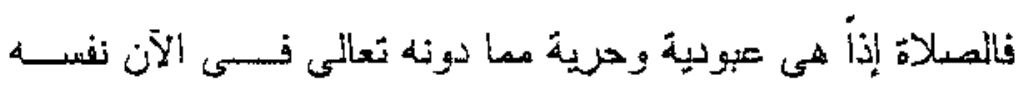

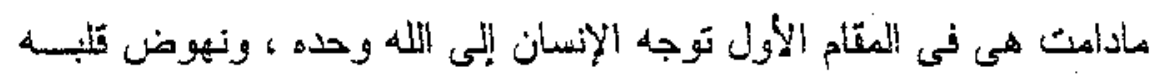

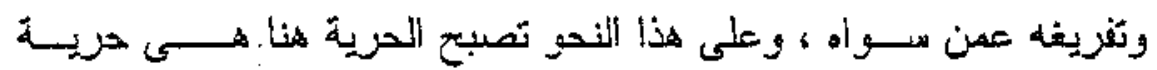

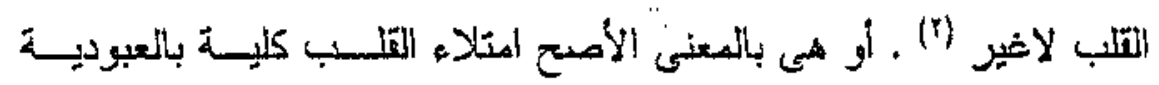

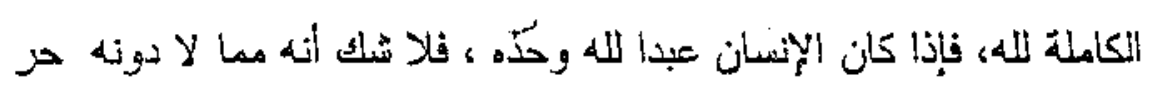

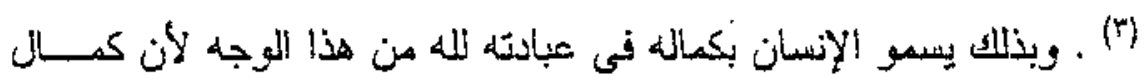

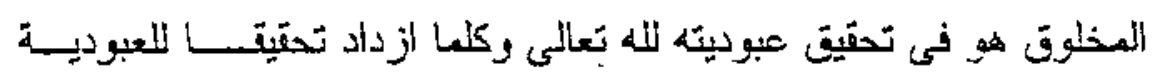

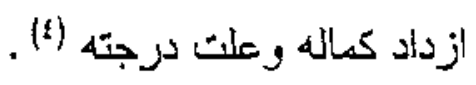

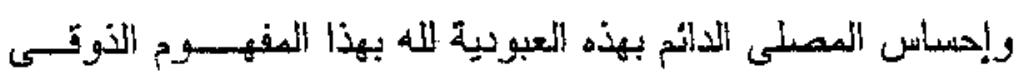

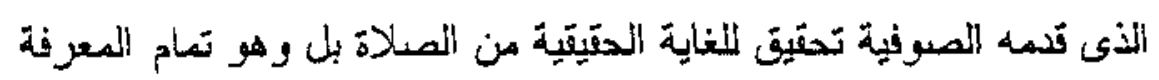

ابن عربى : النتوحات المكية - السنز العـابع مل 110 ، وأيضـ العــنر الأمن صن : 111.

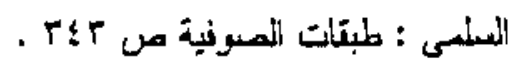

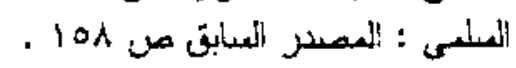

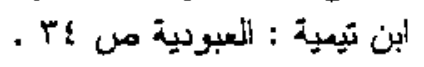




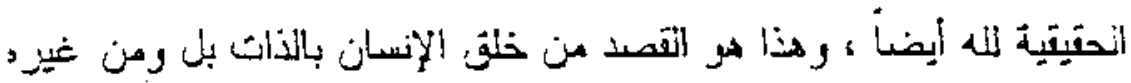

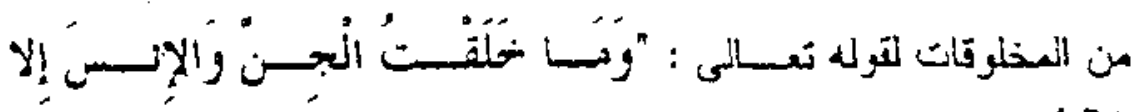
(1)

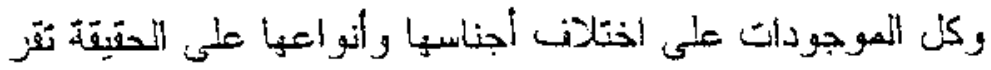

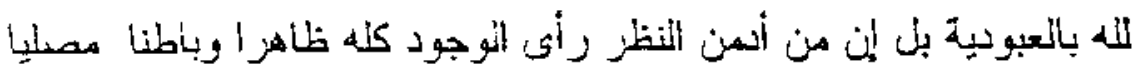

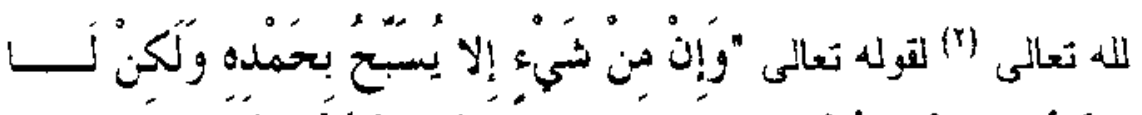

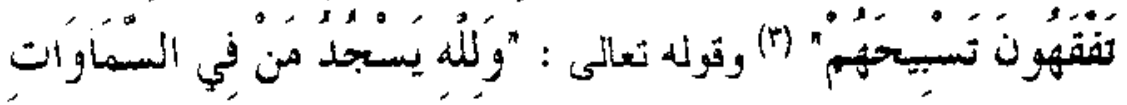
(1) " "الأ

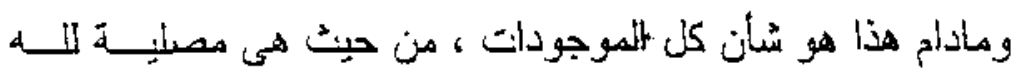

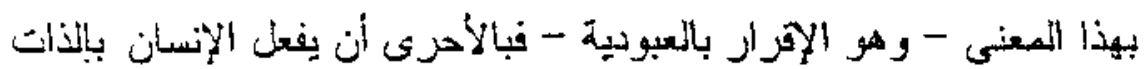

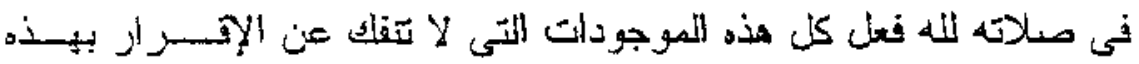

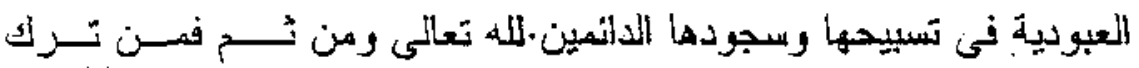
المصلاة بوذا المفهوم بالذات ، فقد خالف الخليقة كلها ، وأخل بنظام إلعــالم

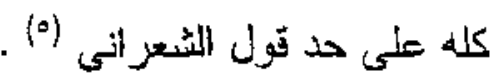
فإلذا تحتق المصلى في صدلاته بالعبودية الكاملة لله ، فتــد حتسفق

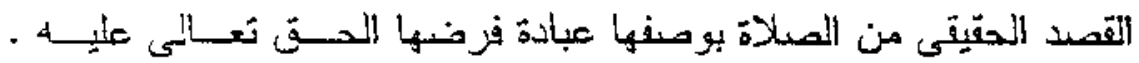

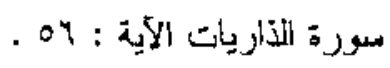

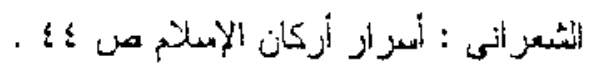

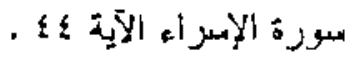

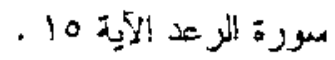

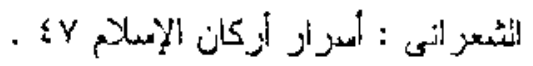




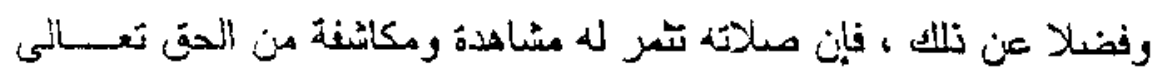

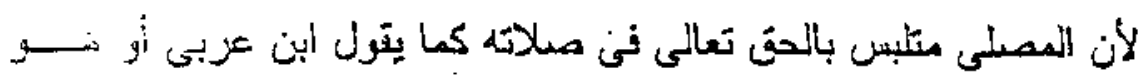

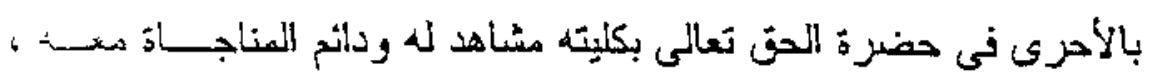

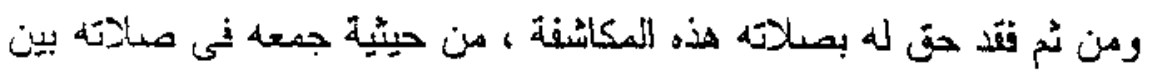

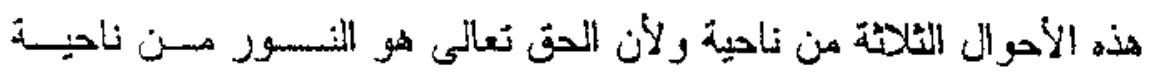

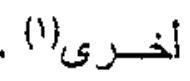

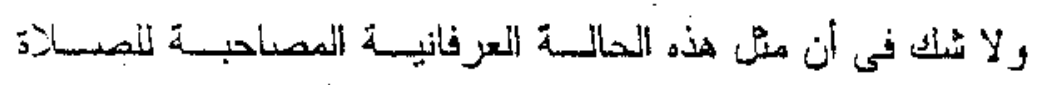

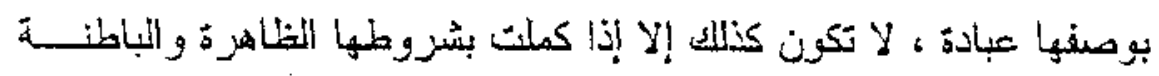

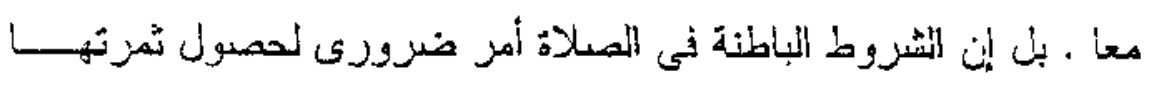

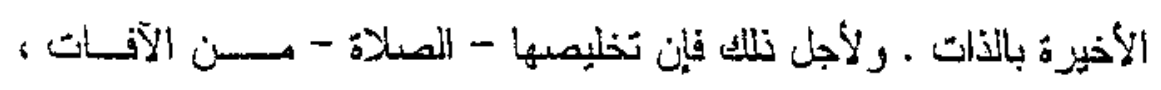

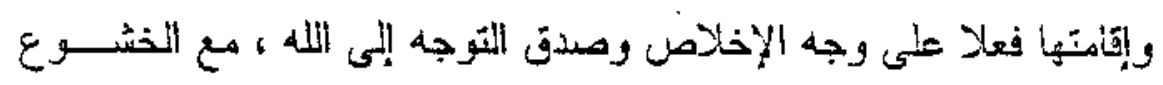

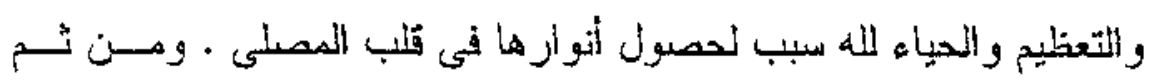

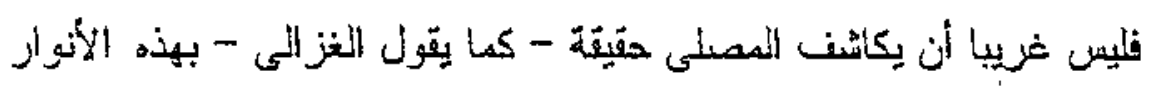

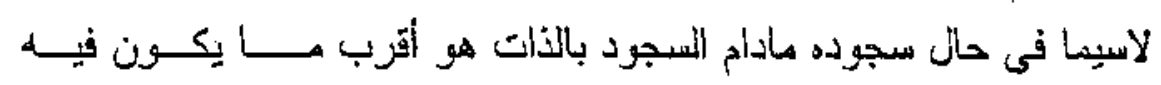

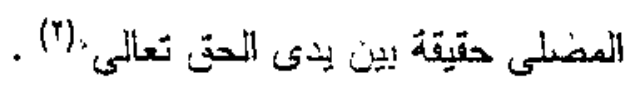

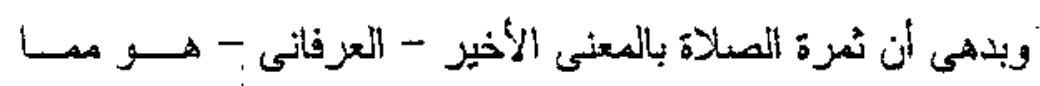

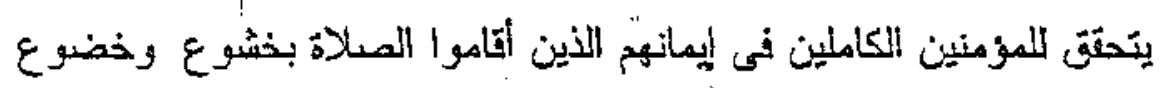

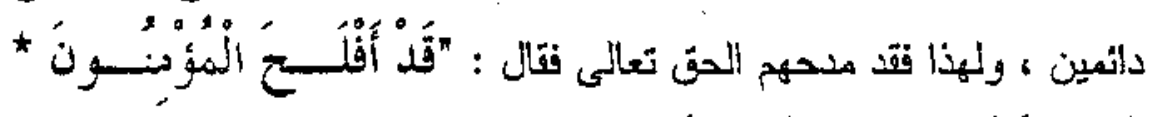

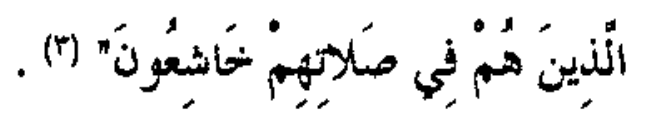

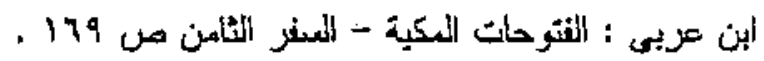

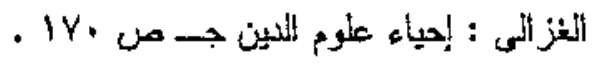

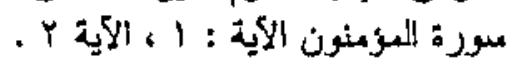


الأمر الأذى يعنى أن مدح الله تعالى لهم سبيه النخشوع فى المصلاة

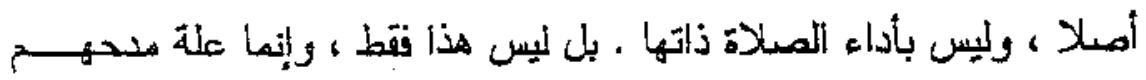

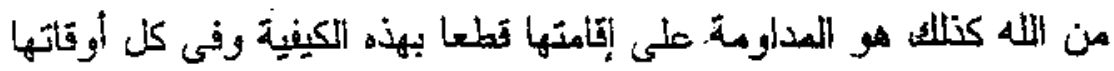

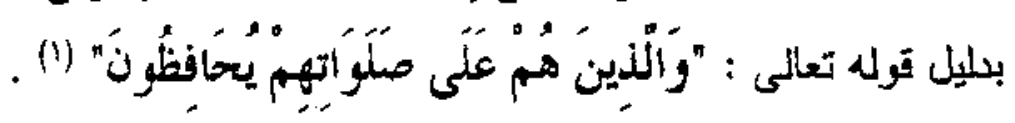

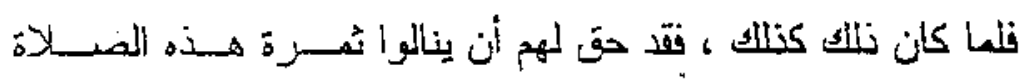

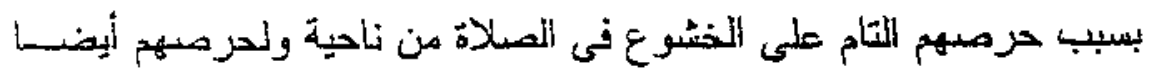

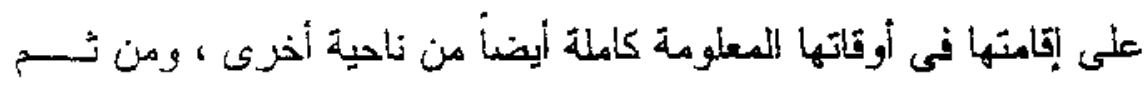

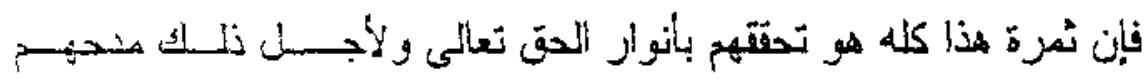

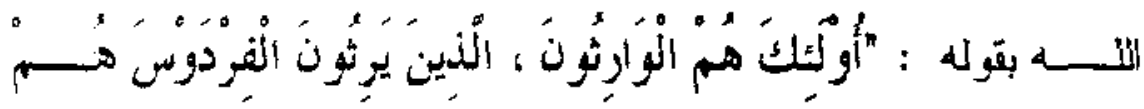

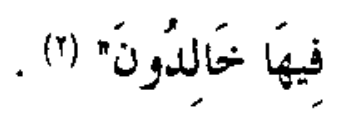

فظاهز من ثلك النصوص القرآنية السابقة ، أن أمر الصسلاة جنيم،

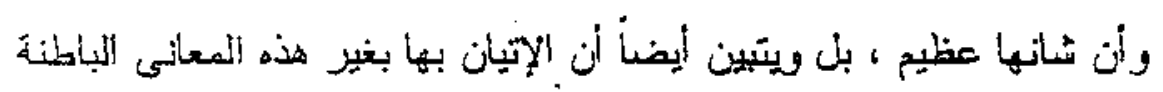

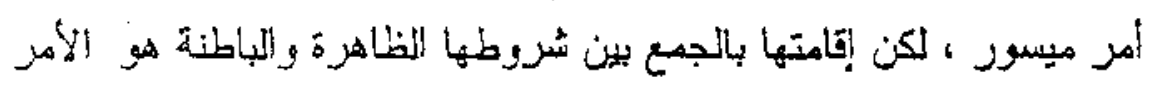

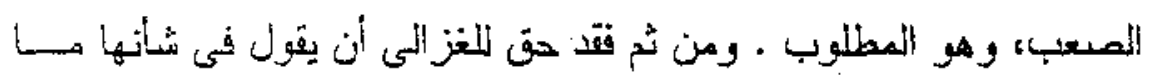

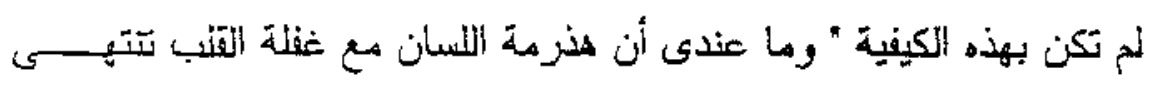

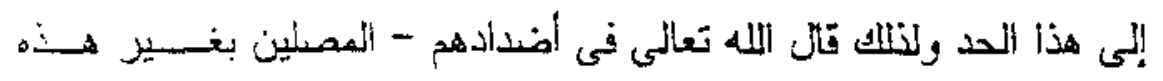

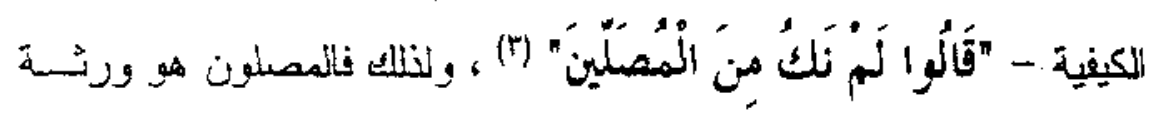

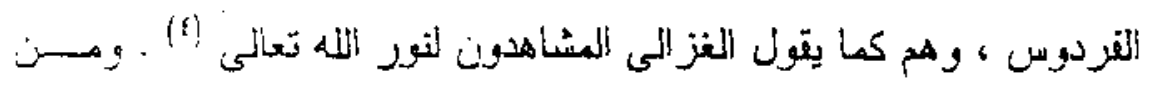

$$
\begin{aligned}
& \text { سورة المومنون الأية } 9 \text {. . }
\end{aligned}
$$

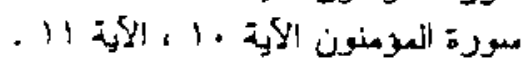

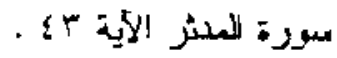

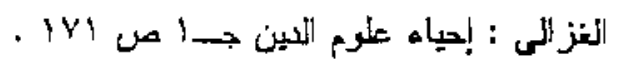




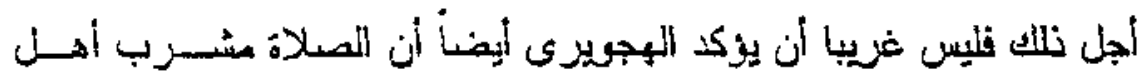
(1) الاستئامة الجن

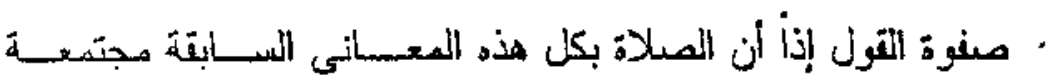

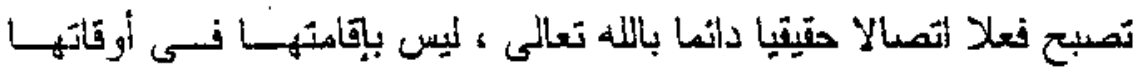

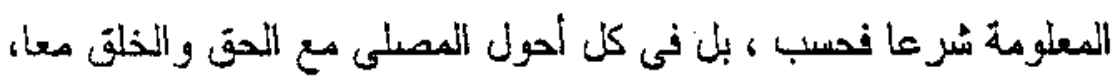
مادامت الصـلحة لا تتفك عن هذه المعانى الخظقية والمزوحية ولهذا السبب

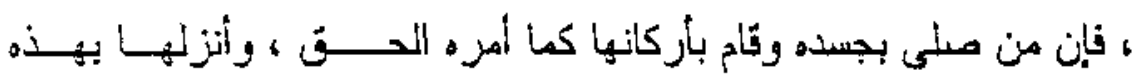

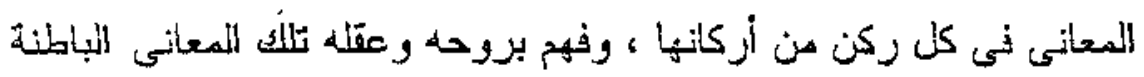

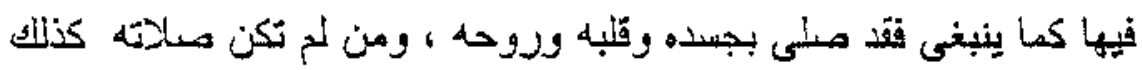

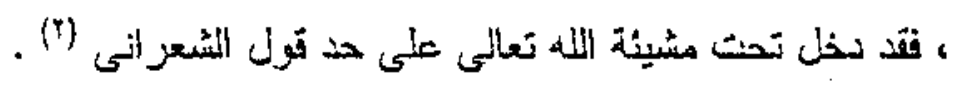

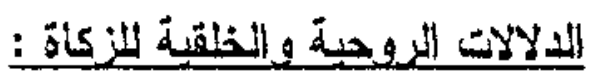

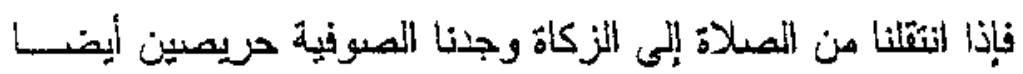

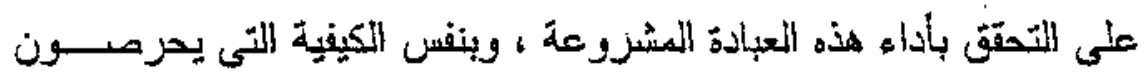

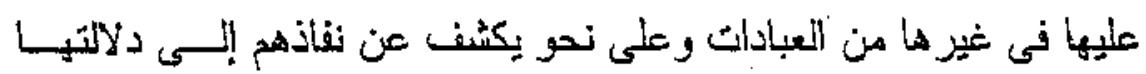

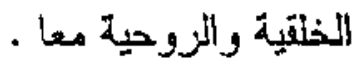

والززكاة عبادة مأمور بها ، فهى فريضدة من فرائض الإسلام بعسـد

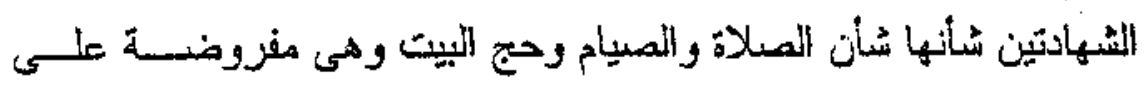

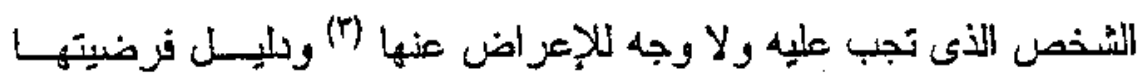

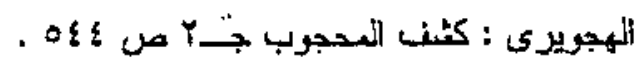

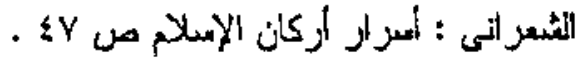

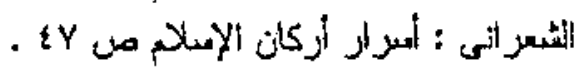




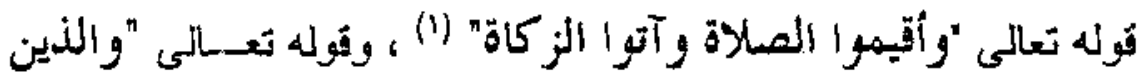

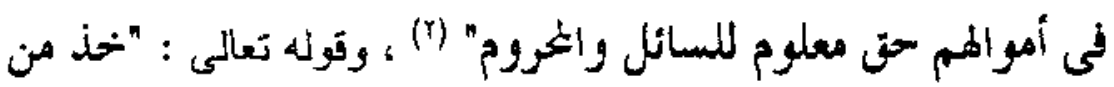

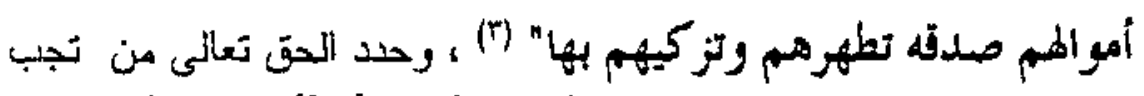

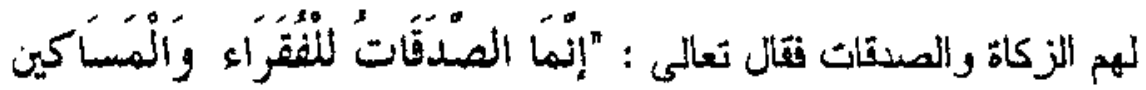

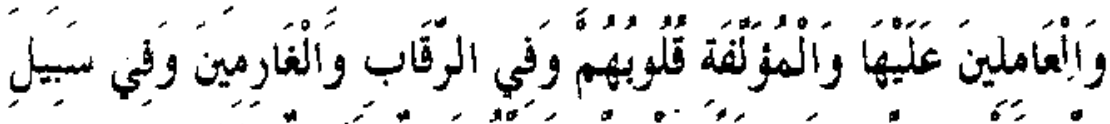

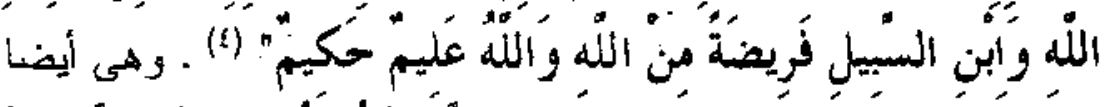

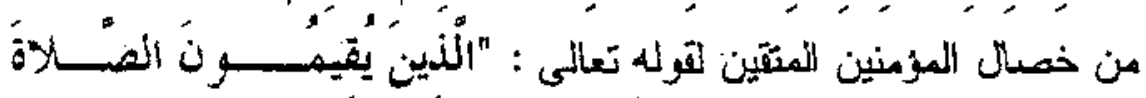

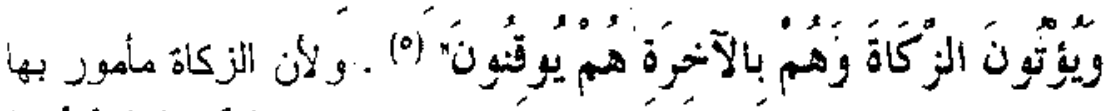

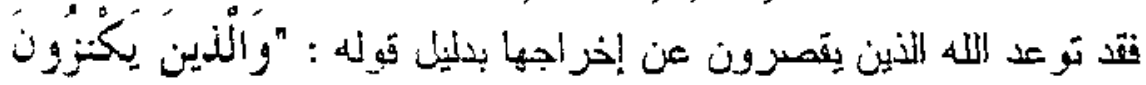

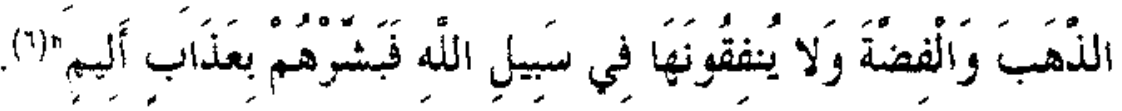

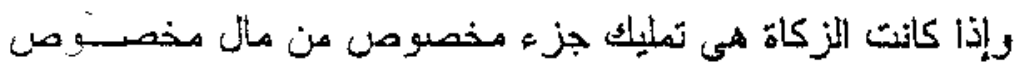

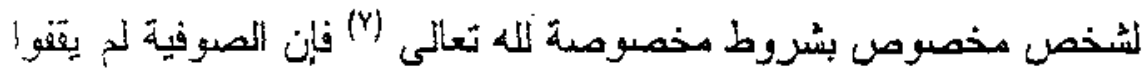

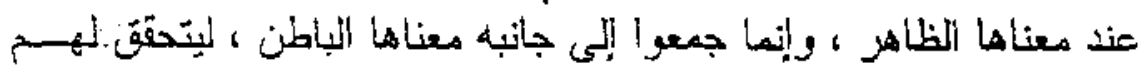

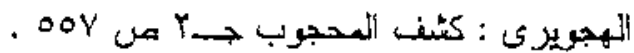

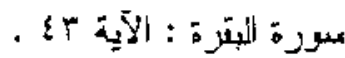

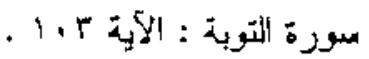

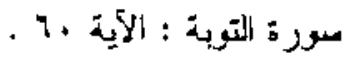

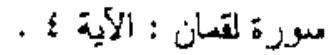

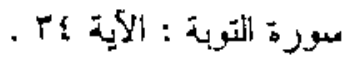

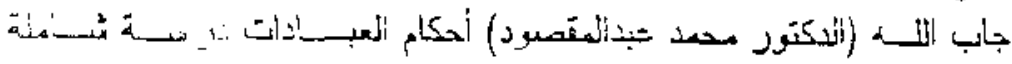

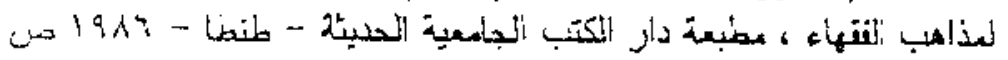

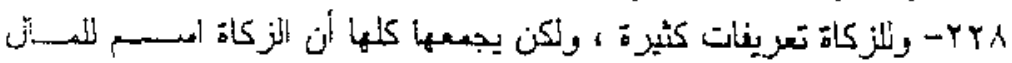

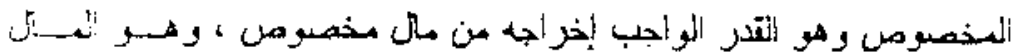

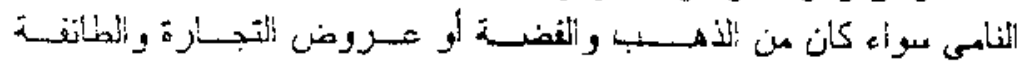

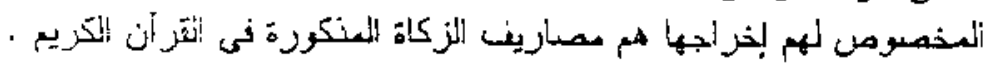




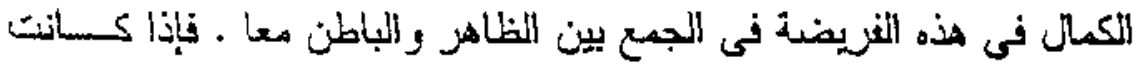

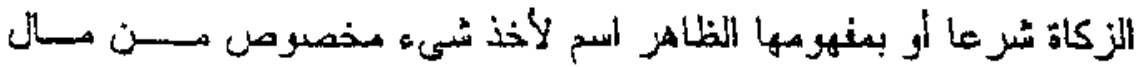

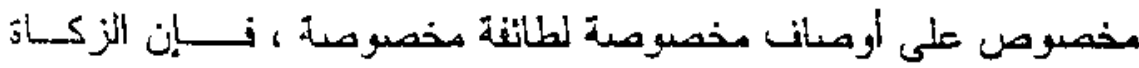

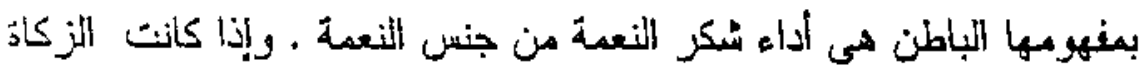

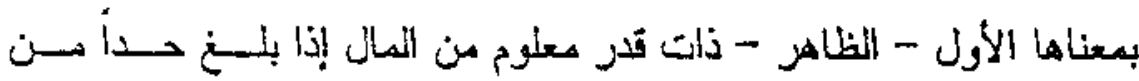

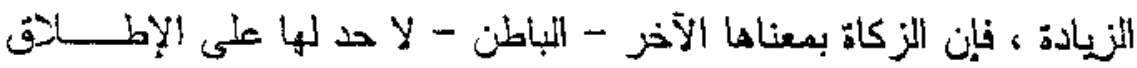

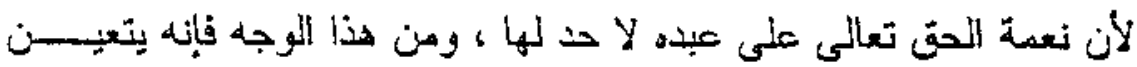

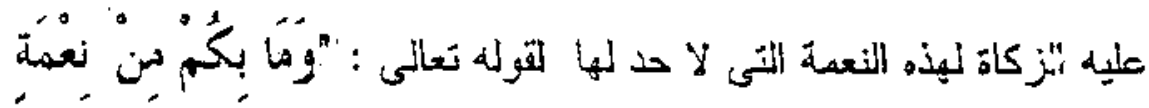

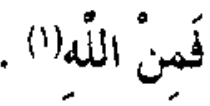

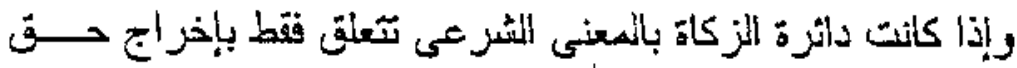

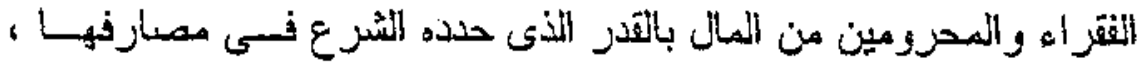

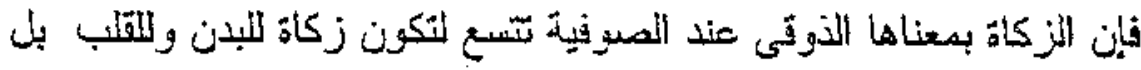
ولاله كذلك .

ولكن أول ما ينبغى على اللعيد في شأن الزئاة هو أن يعلم إلحكمة

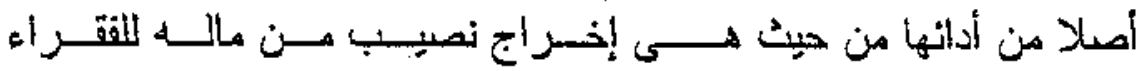

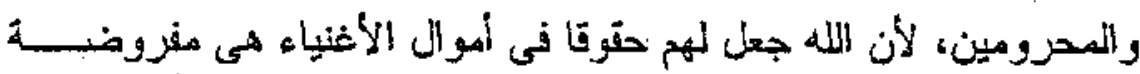

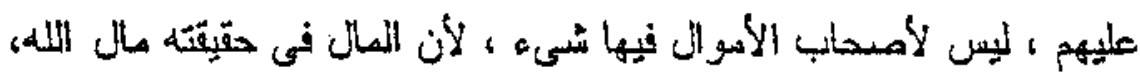

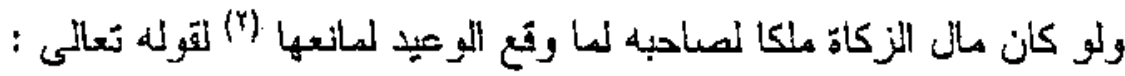




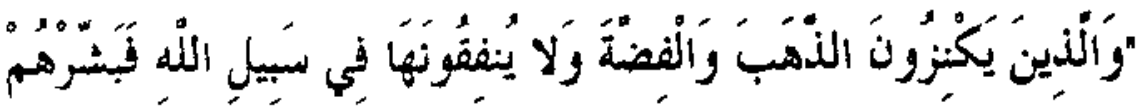

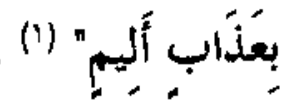

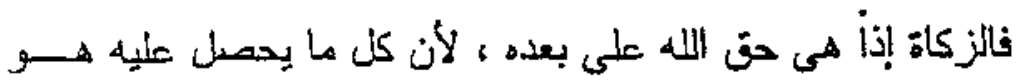

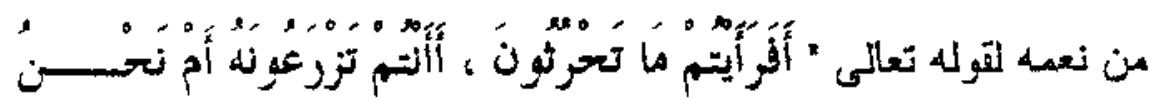

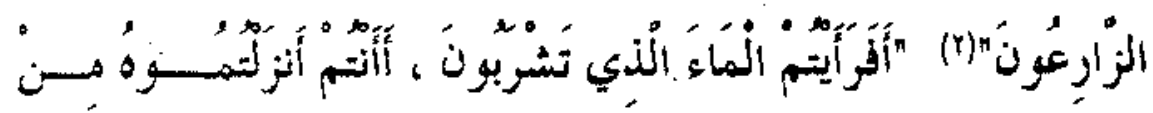

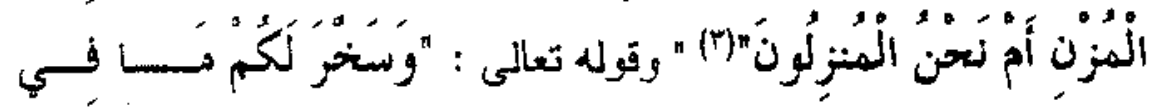

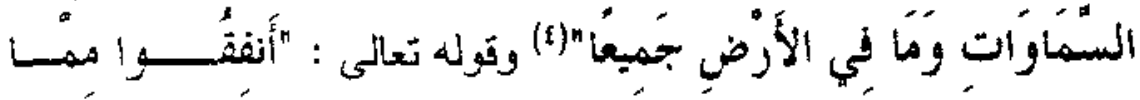

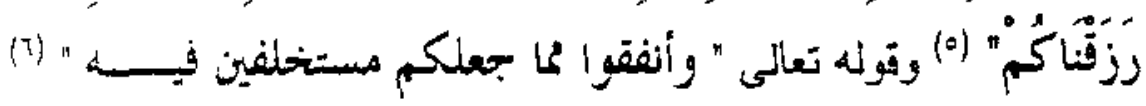

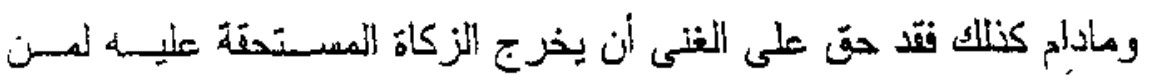

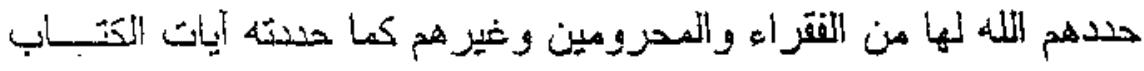

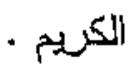

وفئلا عن هذا ، فالزكاة أيضا حق للنقير على الغنى ، لأن حكة

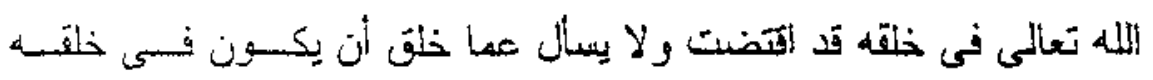

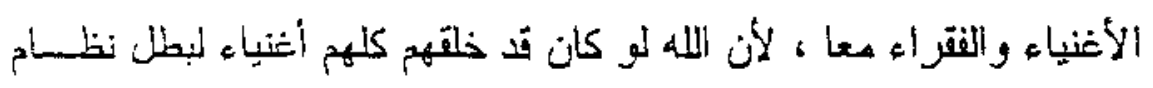

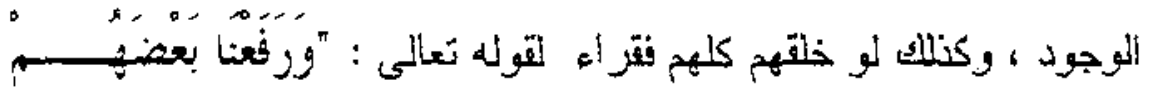

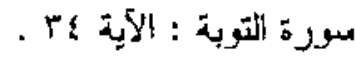

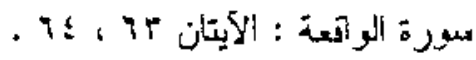

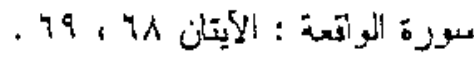

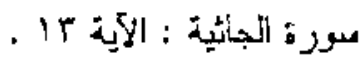

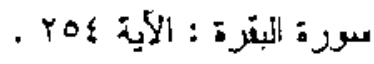

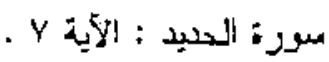




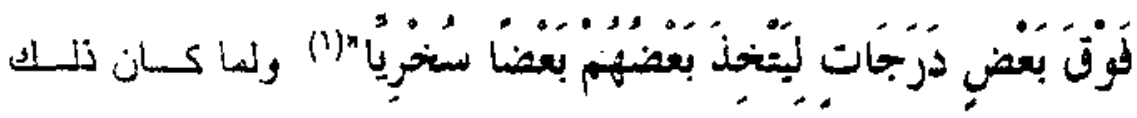

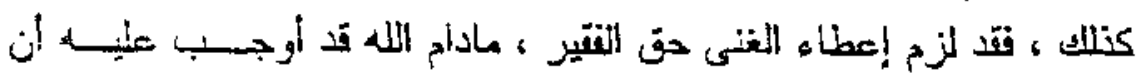

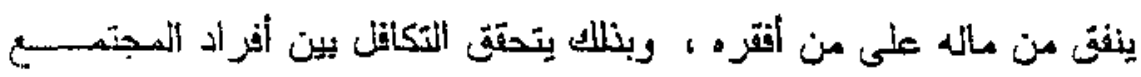
(r) الإثنسانى

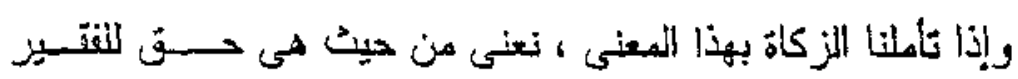

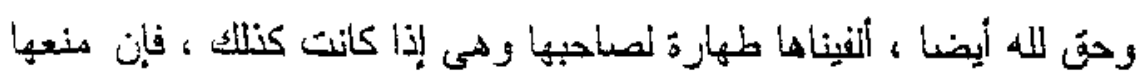

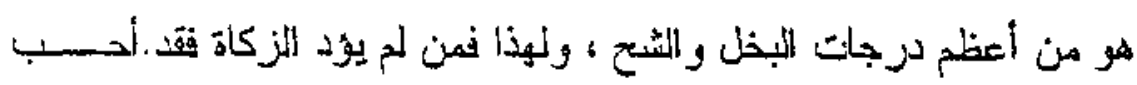

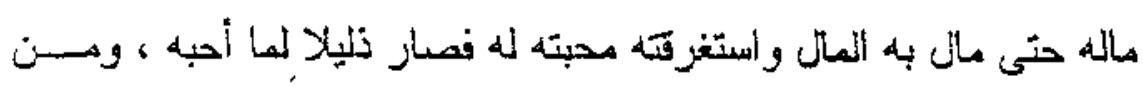

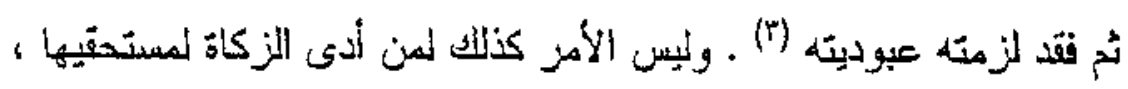

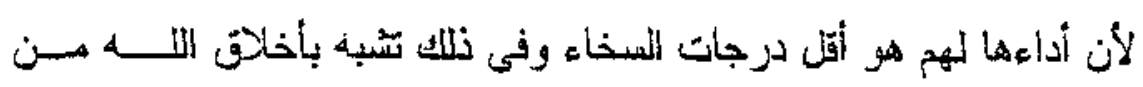

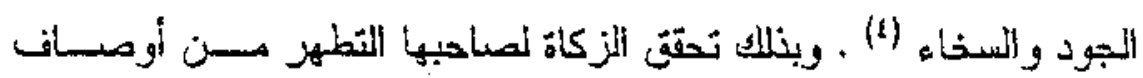

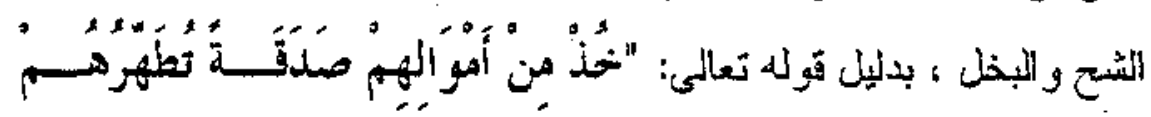

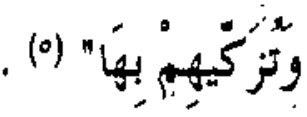

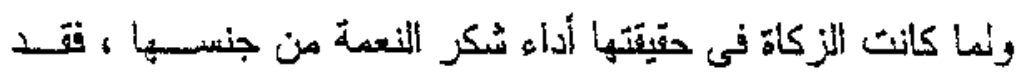

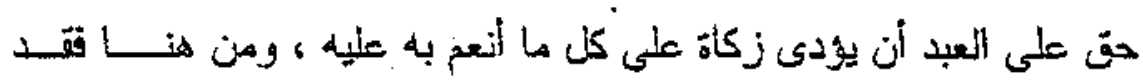

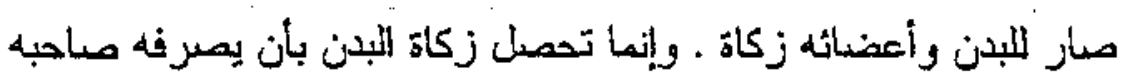

$$
\text { سورة الزخرف : الأية بم . }
$$

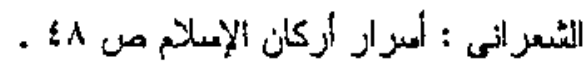

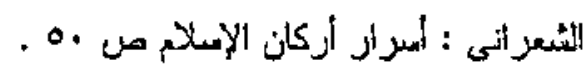

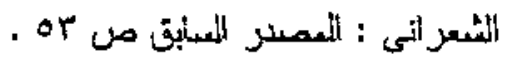

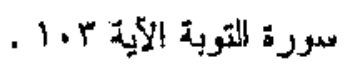


فيما أمر ، النه به ، وبأن يحفظ العبد جوارحه بحين تكون مستخرثة فــى

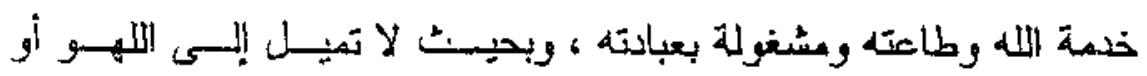

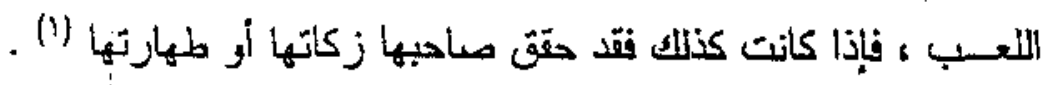
فليس المهم إذاً أداه.حق الزيكاة سوإه كانت زكاة للمبـان أو زكــاة

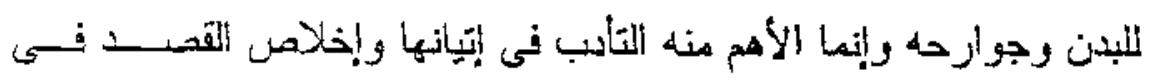

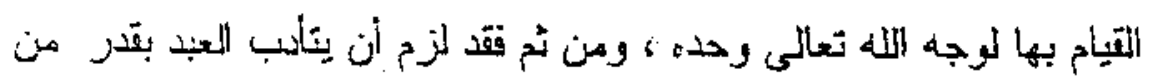

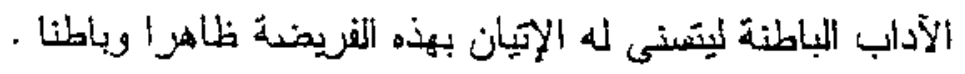

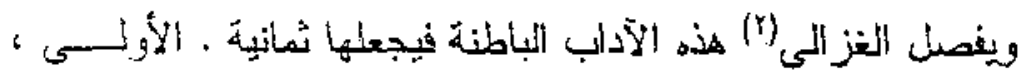

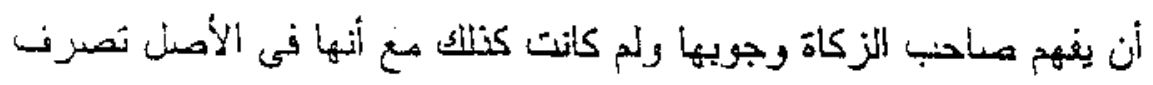

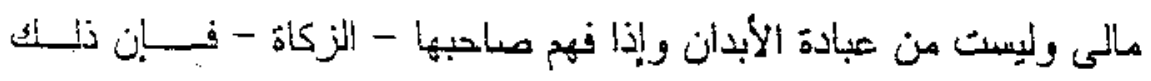

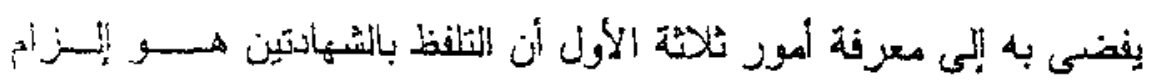

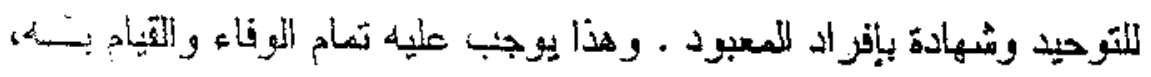

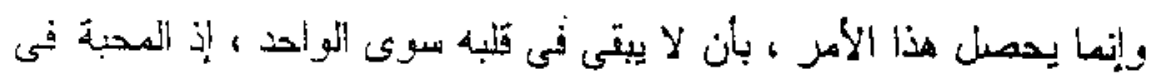

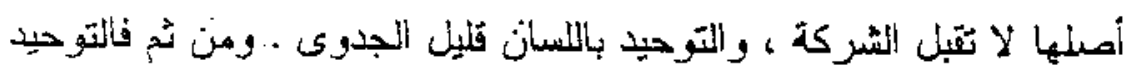

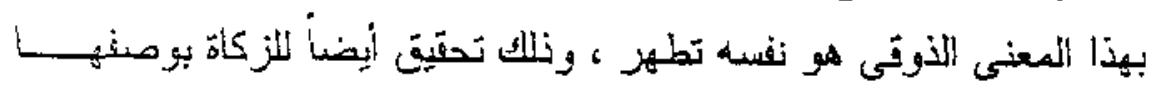

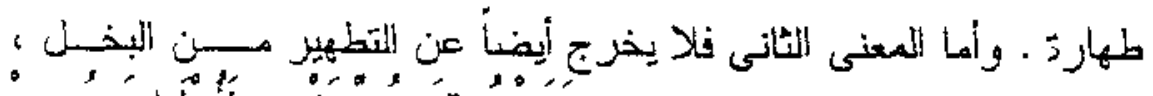

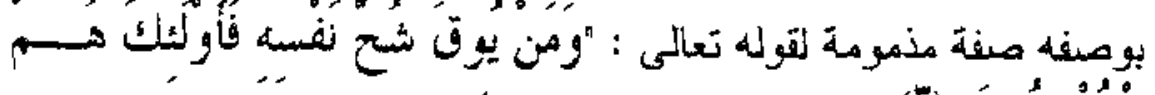

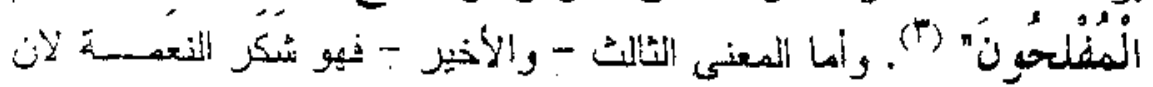

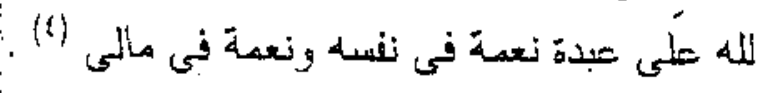

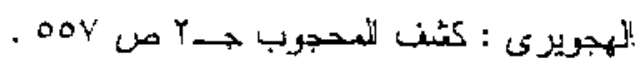

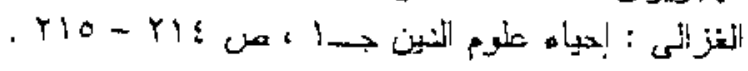

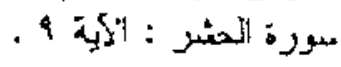

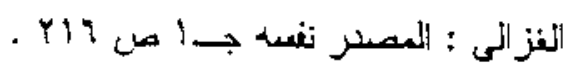




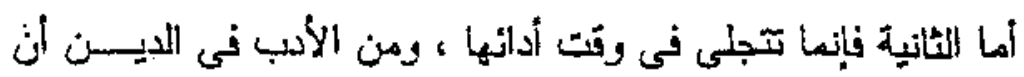

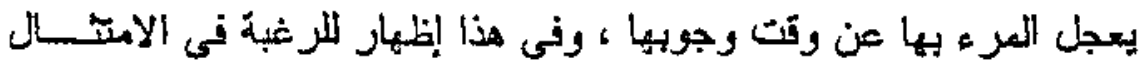

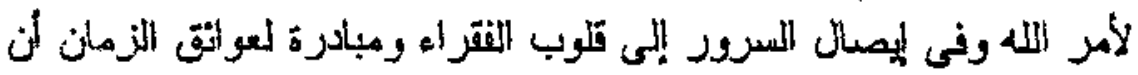

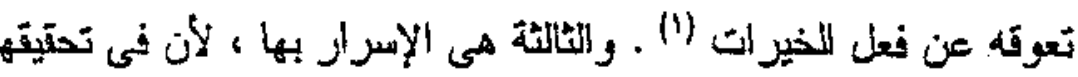

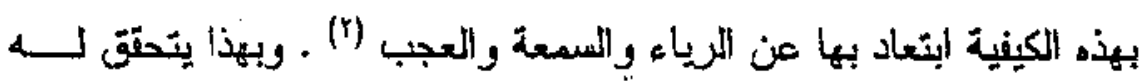

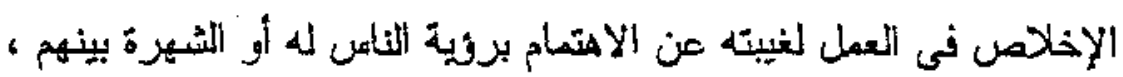

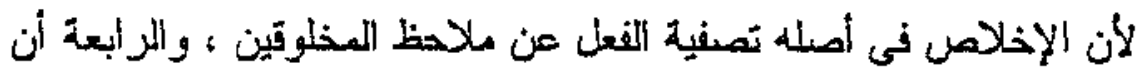

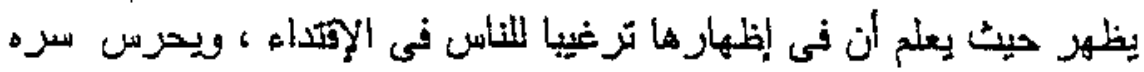

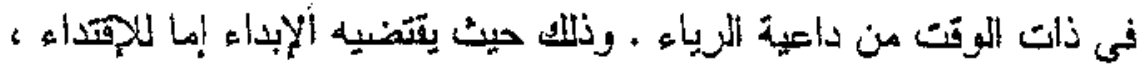

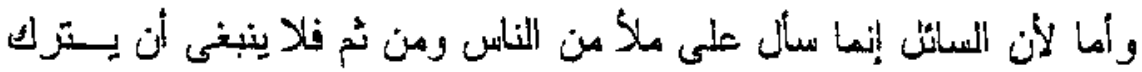

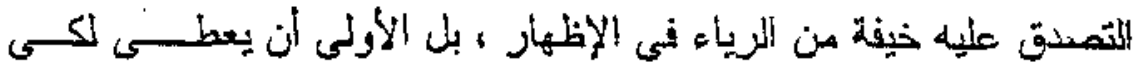

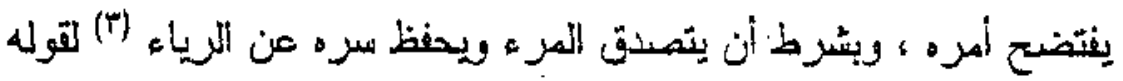

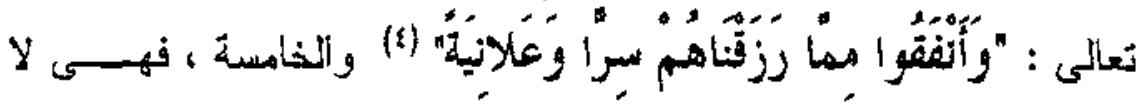

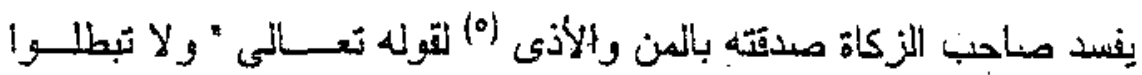

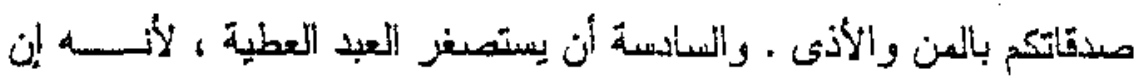

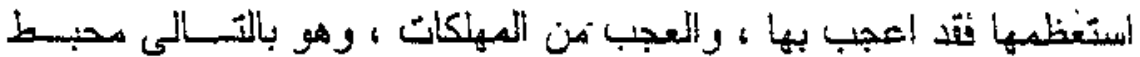

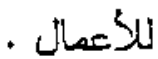

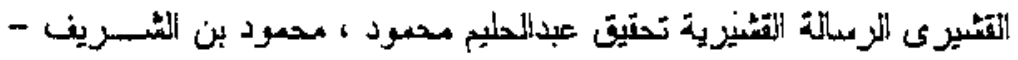

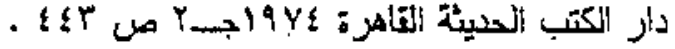

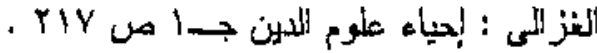

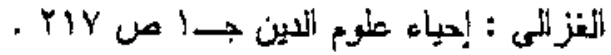

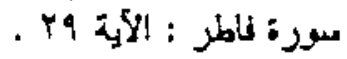

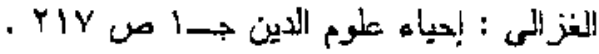




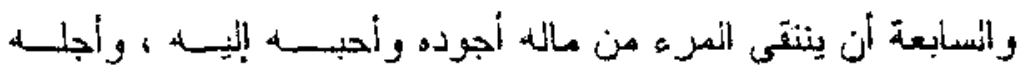

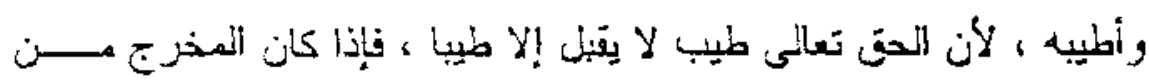

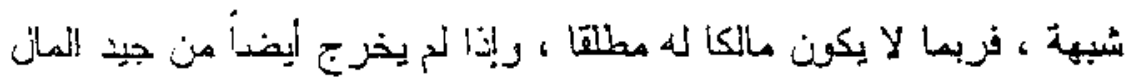

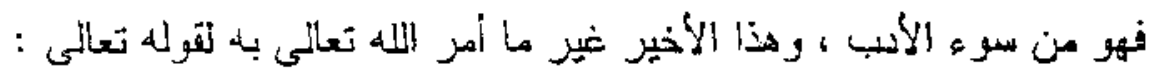

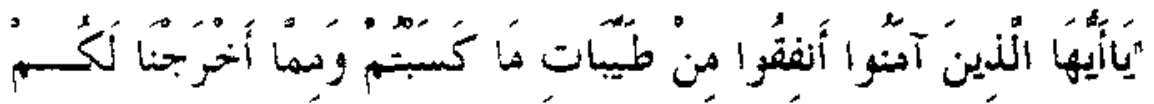

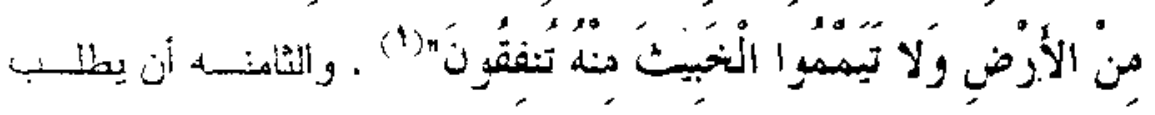

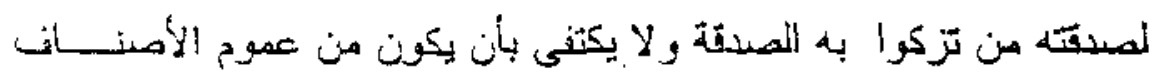

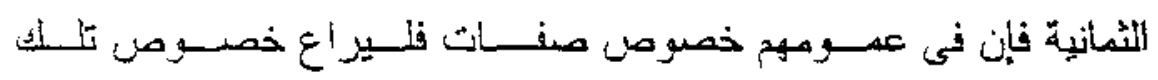
الصفاتب(r)

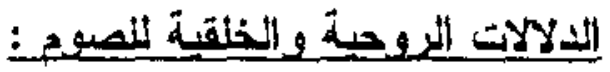

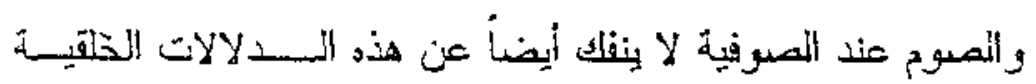

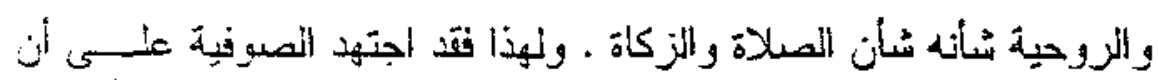

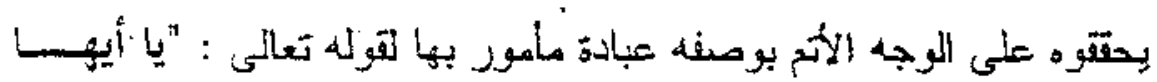

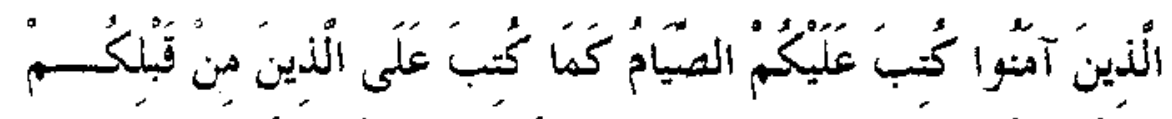

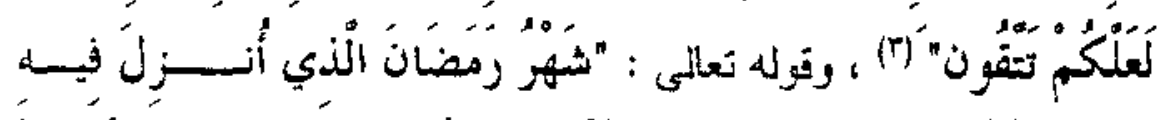

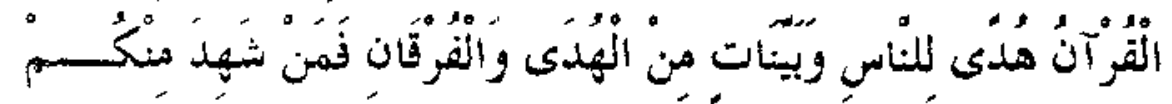

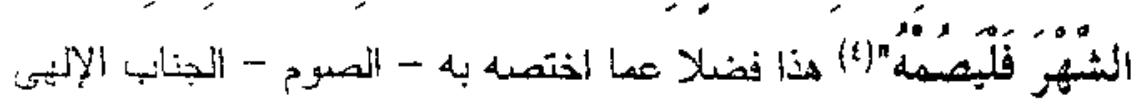

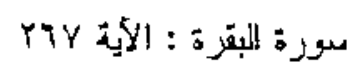

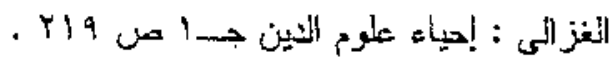

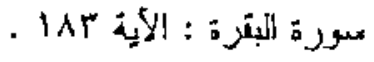

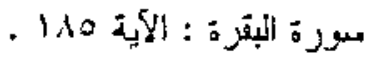




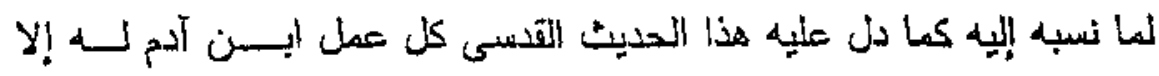

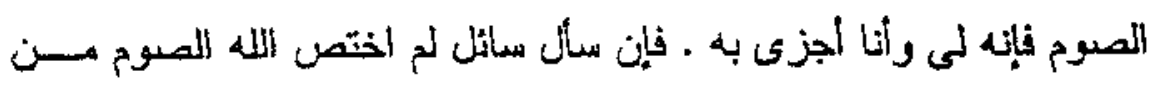

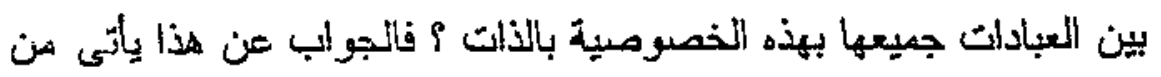
جهتين : جهن

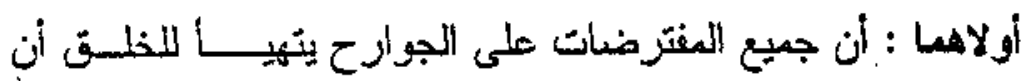

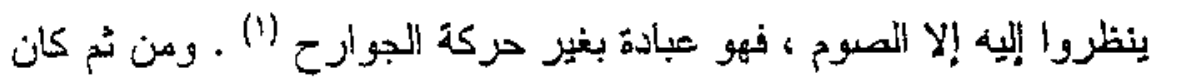

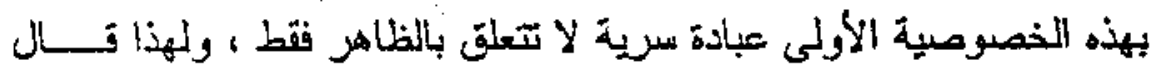

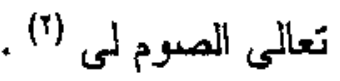

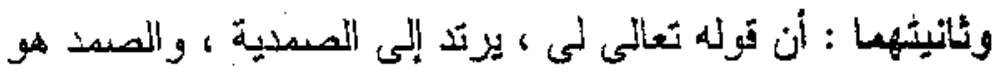

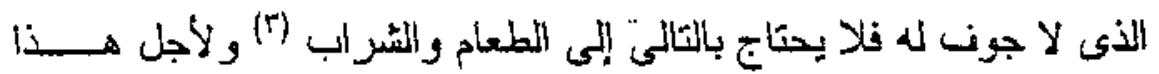

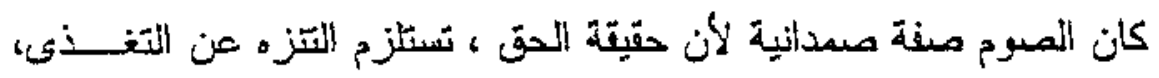

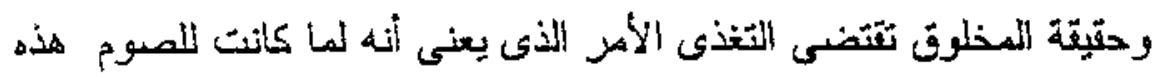

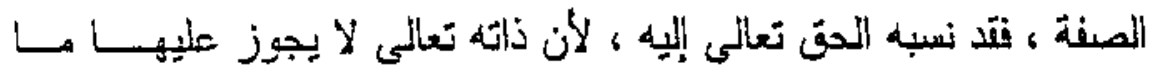

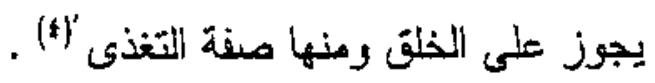

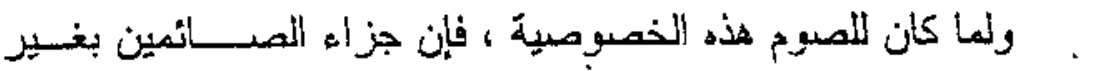

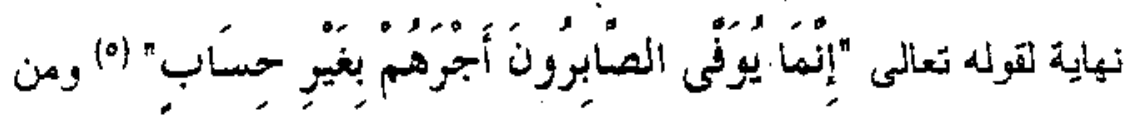

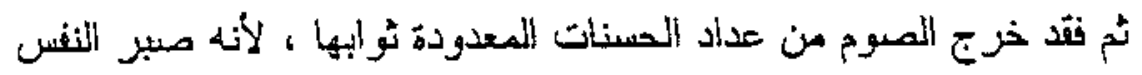

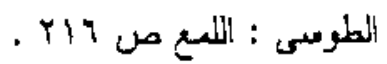

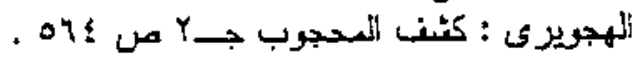

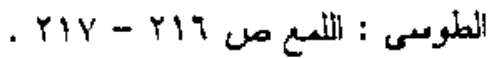

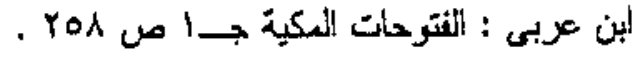

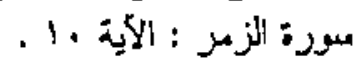




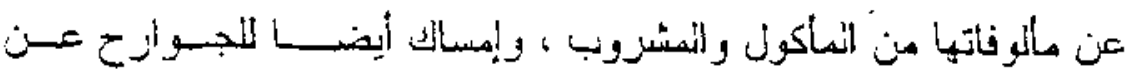

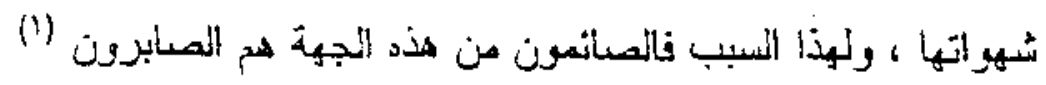

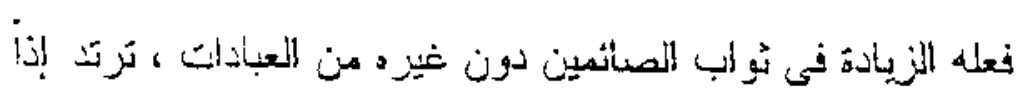

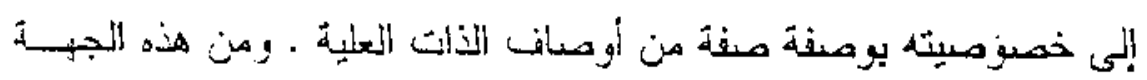

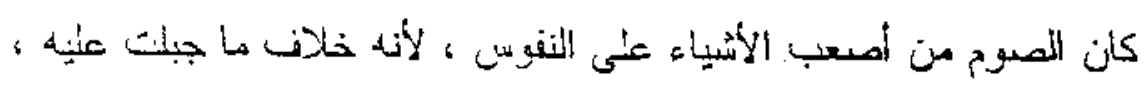

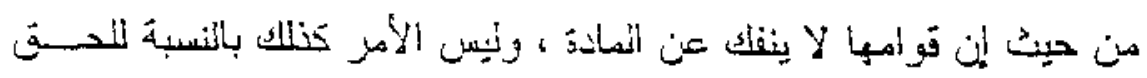

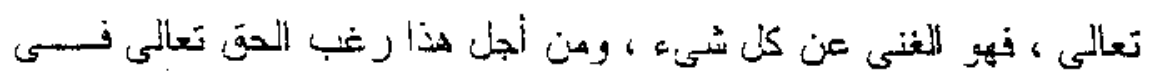

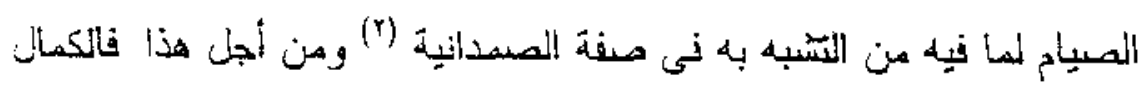

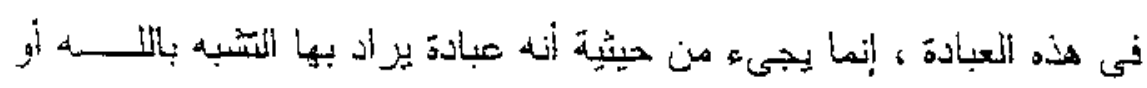

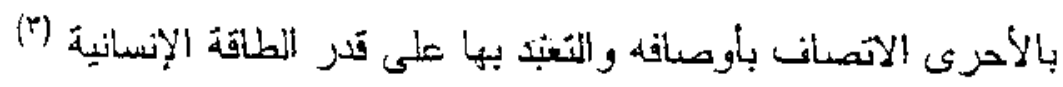

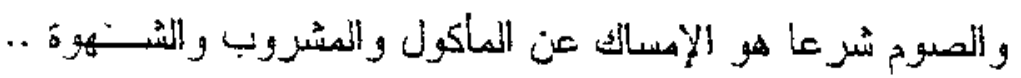

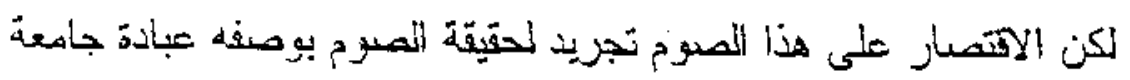

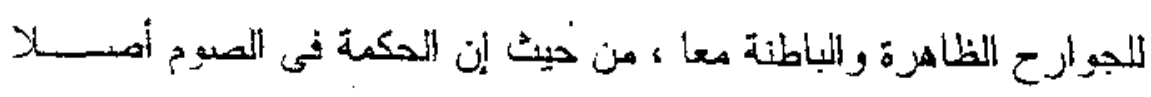

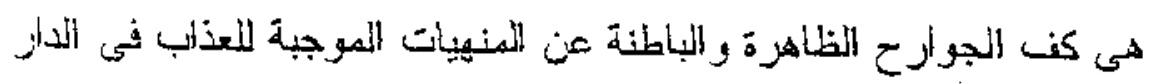

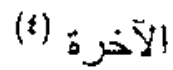

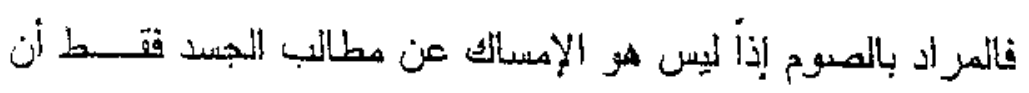

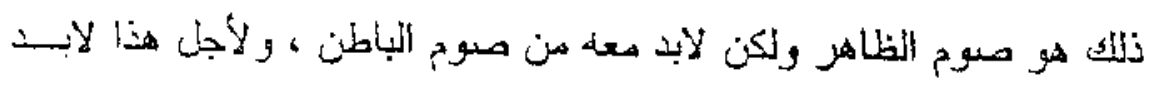

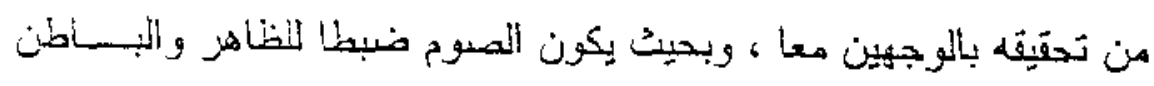

$$
\begin{aligned}
& \text { الطوسيى : اللمع مل YIY - YIY }
\end{aligned}
$$

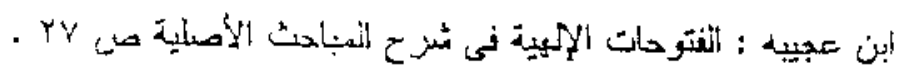

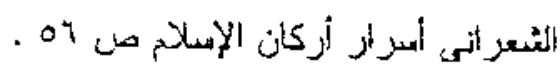

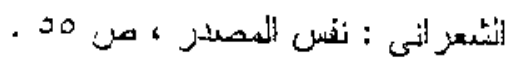


معا ـ وكما أن الاول-الظاهز - يحصل بكن الجسد وإمساكه عن الطعام،

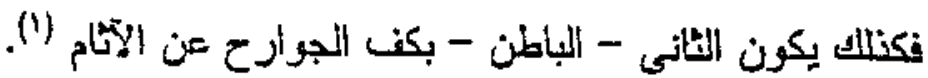
وإذا كان المور المشروع هو الإهساك من المأكول والمشـــــوب

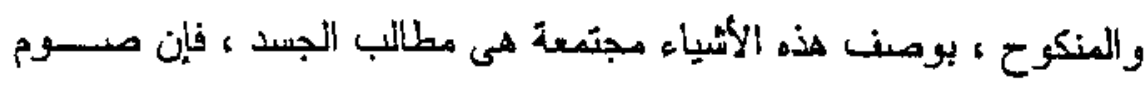

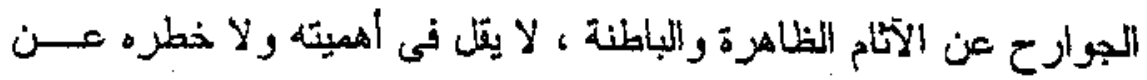
صورم الجيسد كثلـ .

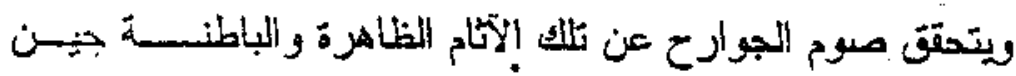
يحفظ العبد لكل جارحة من هذه الجوارح وظيفتها التي من أجلها خلقت له له

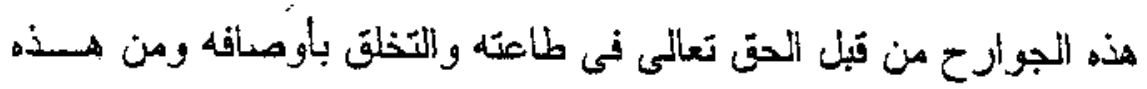

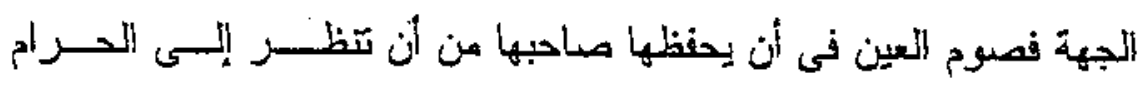

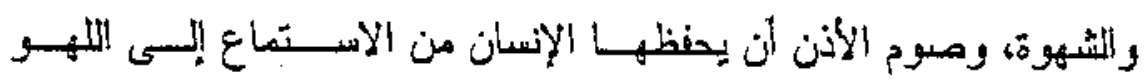

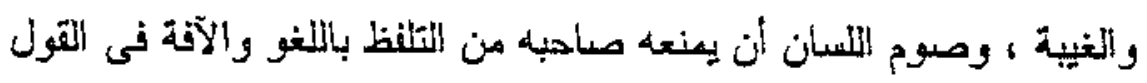

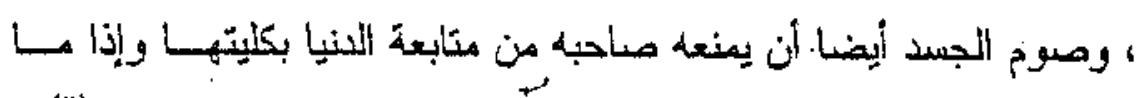

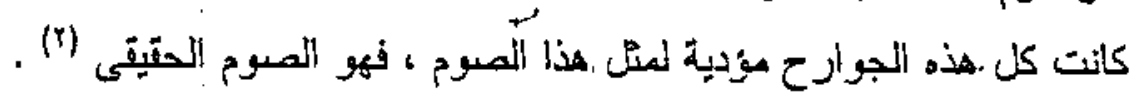
وعله الأمر فى هذا لن تحقيق صوم الجوالرح على هذا النحو إنسا

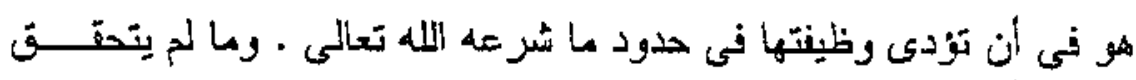

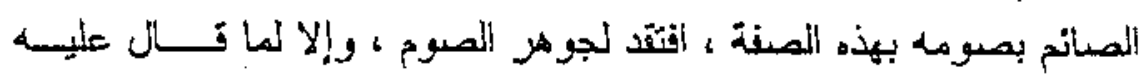

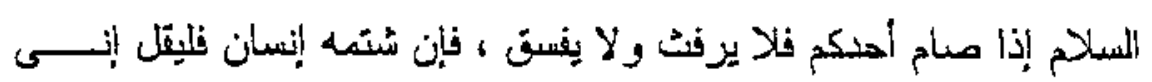
صانم

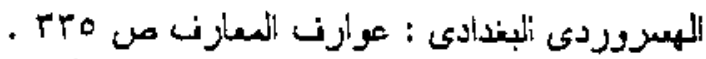

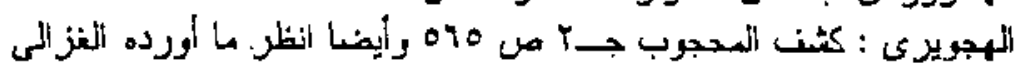

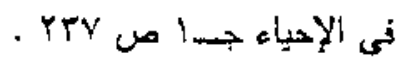




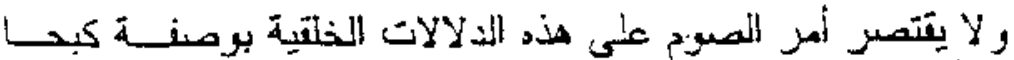

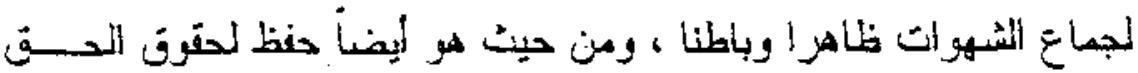
تعالي من ناحية ولحقوث الخلت عليه من ناحية أخرى . وإنما للمسوم أيضـأ

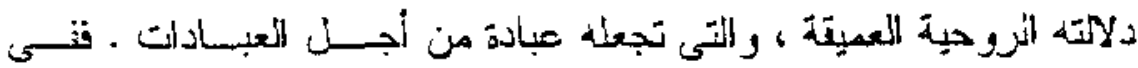

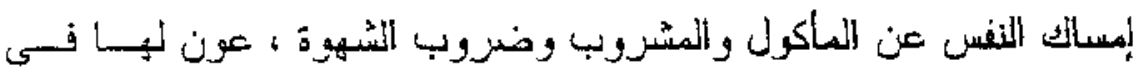

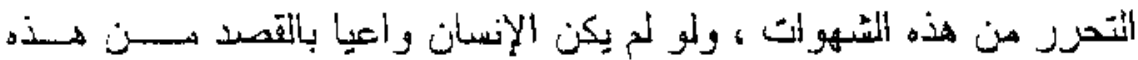
الحقيقة بالذات لاسيترحته الأشياء ، و استعبدته ثشاها و لهذا فرض إلله المصوم

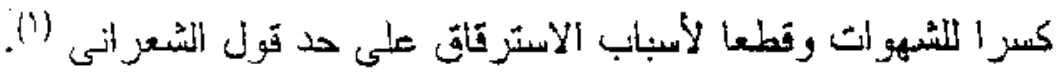
وحين يصبح الصصوم فى جوهره يوذا المعنى الخير بــالذات فانــــ

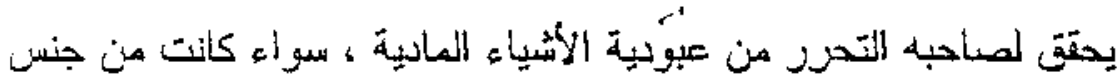

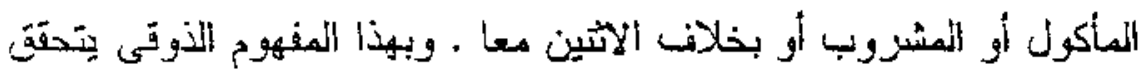

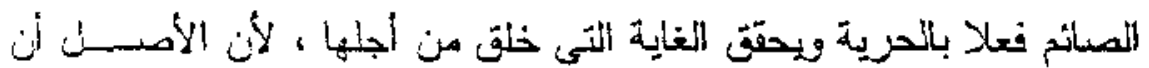

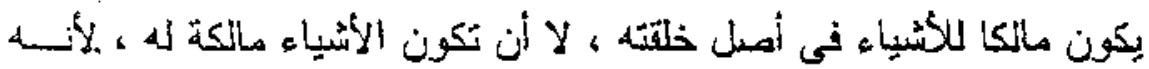
خليفة الله في منكه

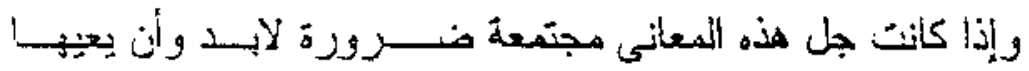

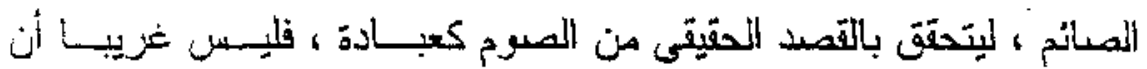

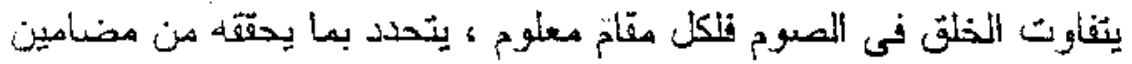

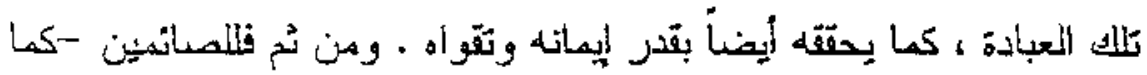

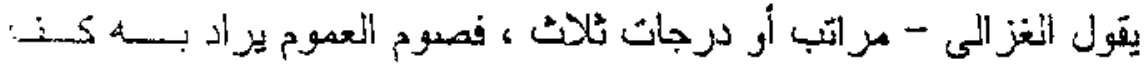

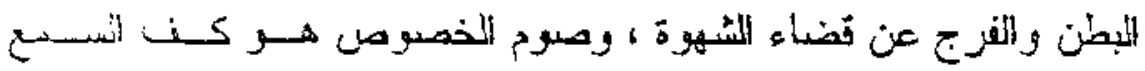

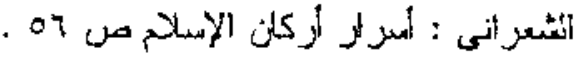

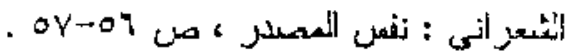




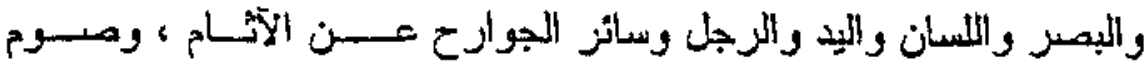

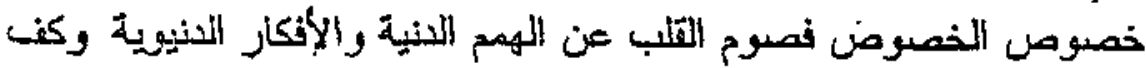

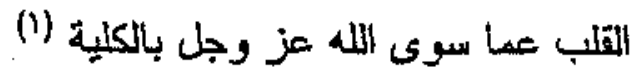

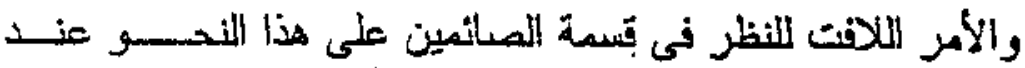

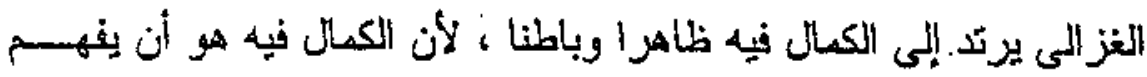

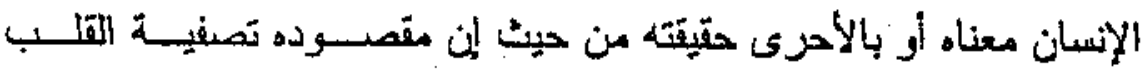

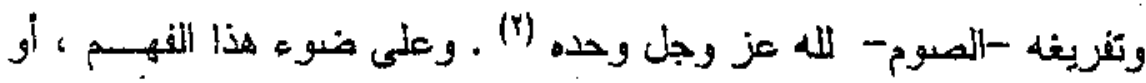

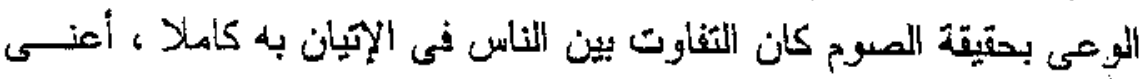

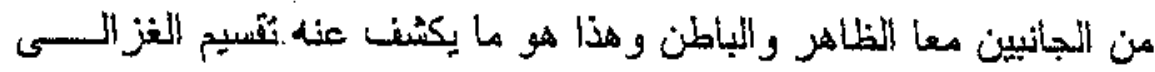

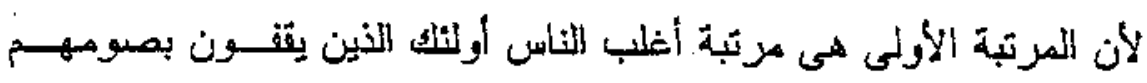

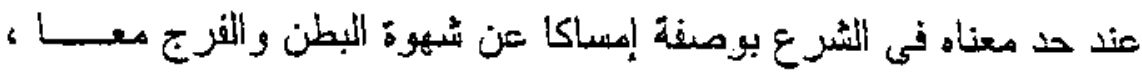

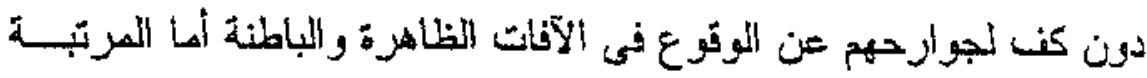

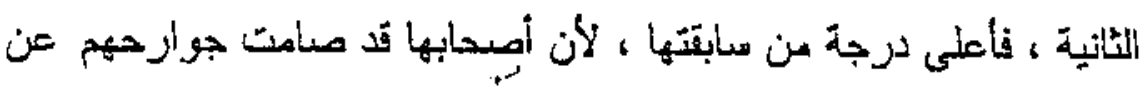

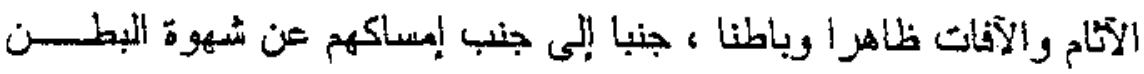

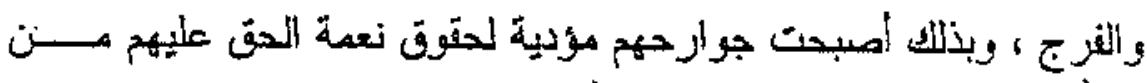

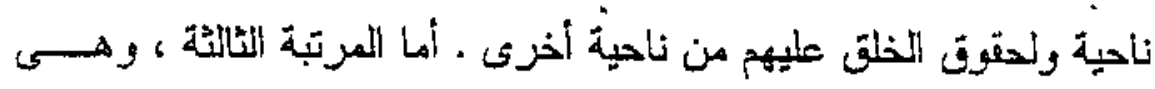

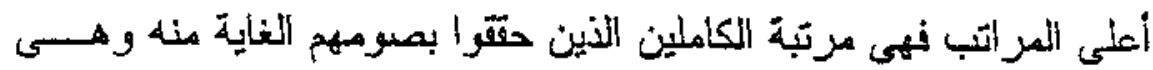

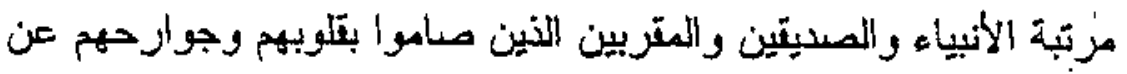

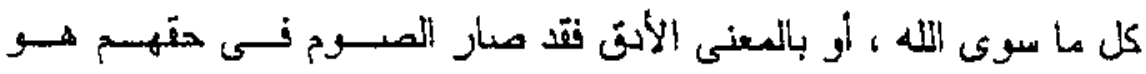

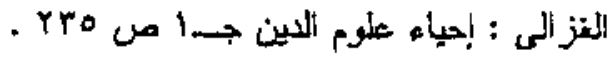

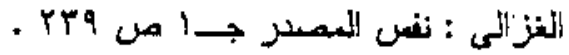


الإمساك عن كل ما سوى اللله حتيتة (1) . ومن الجنى أن هذا هو التقســد

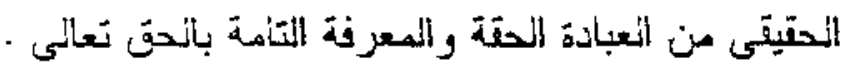

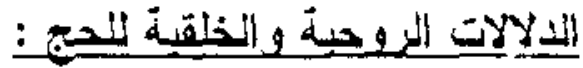

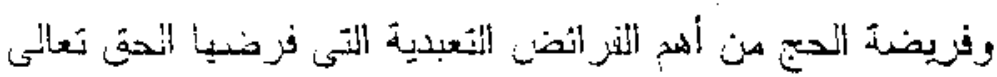

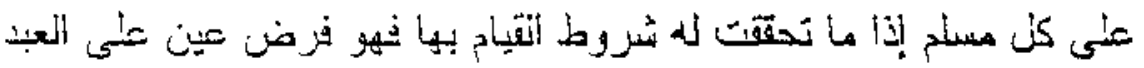

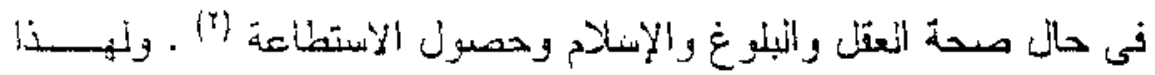

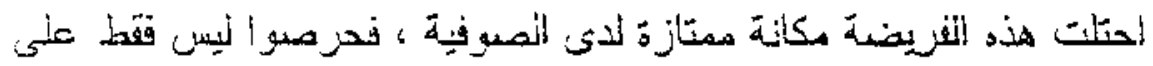

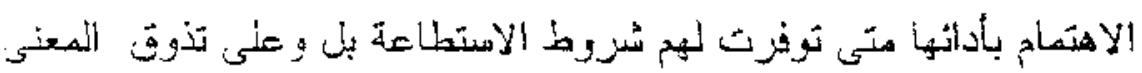

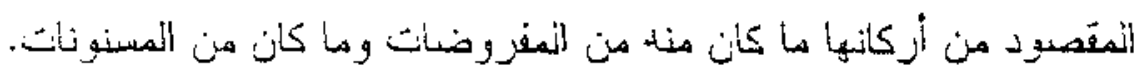

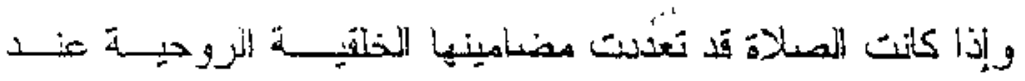

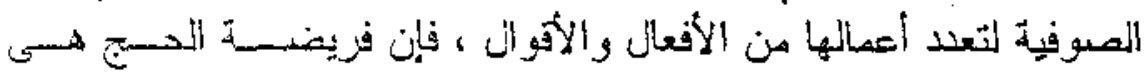

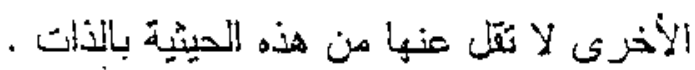

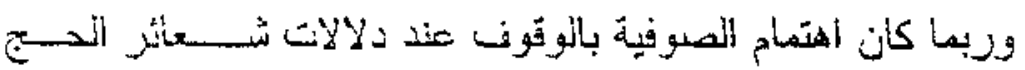

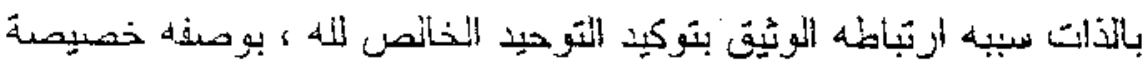

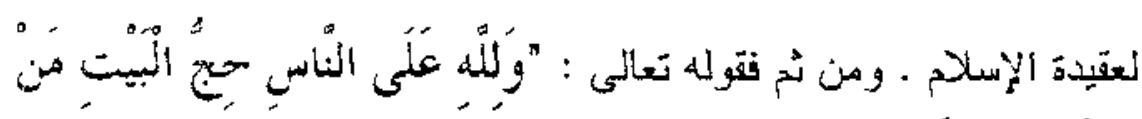

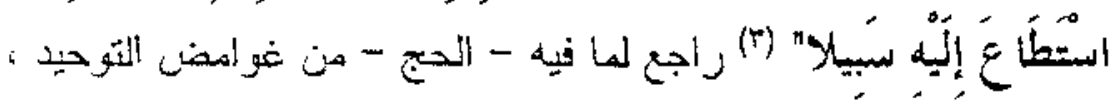

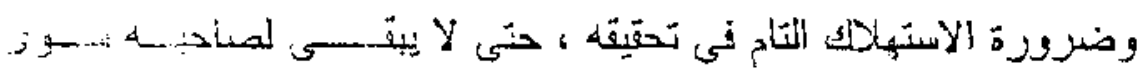

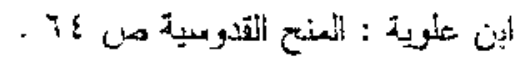

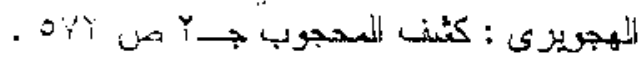

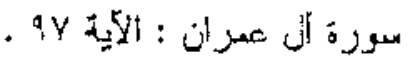




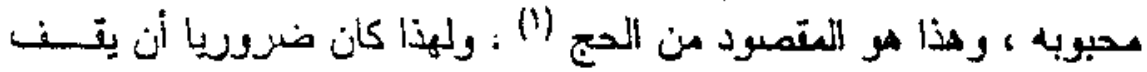

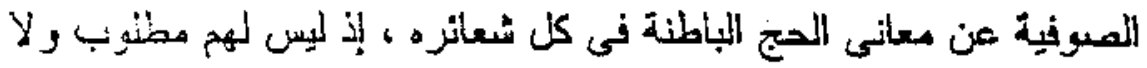

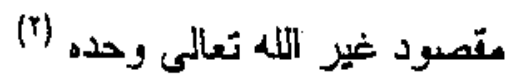
فإذا أرنان أن نكثين عن حقيقة هذه الفريضة - إلحج - ومكانتهيـا عند الصوفية فان أول ما يطالعنا عندهم هر التأكيد على ضرودرة القيام بها

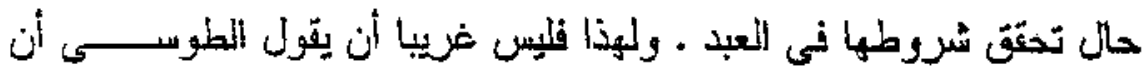

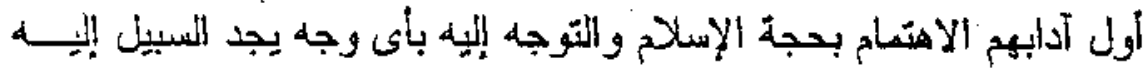
والاستطاعة ، وبحيث لا يركن العبد إلى سعة وطلب المزخصة في الجلوس بلى

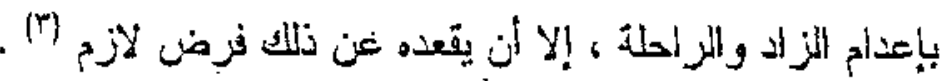
وللحج شروطه وأركانه التى لا بد هن أستيفائها ، وقثل هذا مستـن

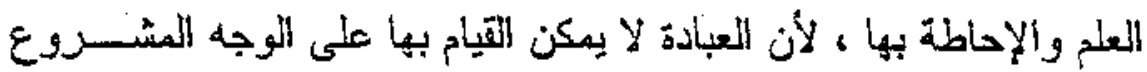

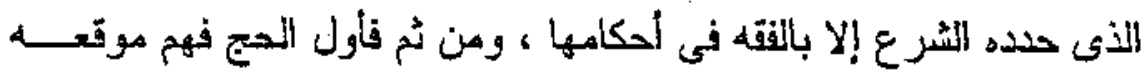
(i) فى الدين لكن الموقون عند حد إقامة شعائر الحج ، من حيث هى عمل البدن

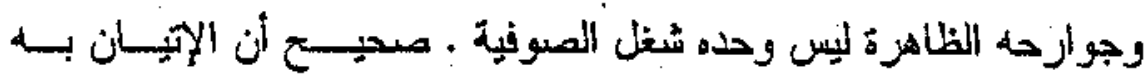

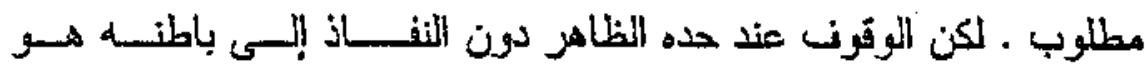

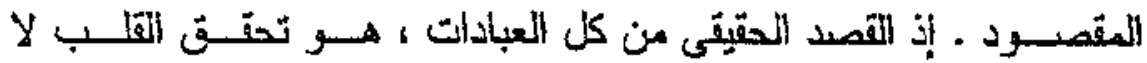

$$
\begin{aligned}
& \text { ابن طنوية : المنح التقوسية صل ؛1 - } 10 \text {. . }
\end{aligned}
$$

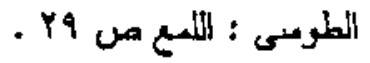

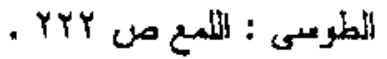

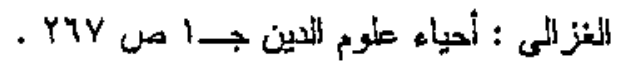


القالب بدكاثقها المقهودة جنباً إلى جنب رسومها المعلومة ـ و هذا ما تحده

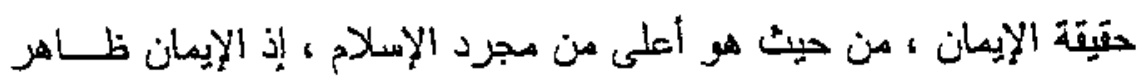

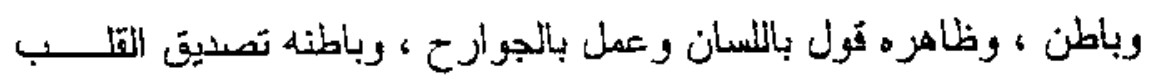

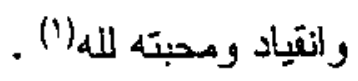

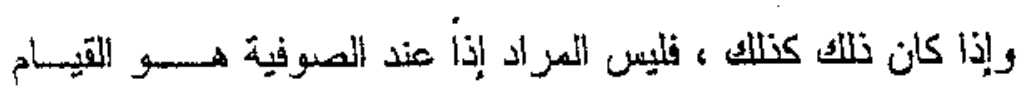

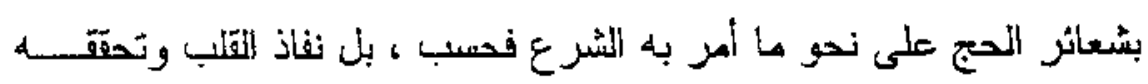

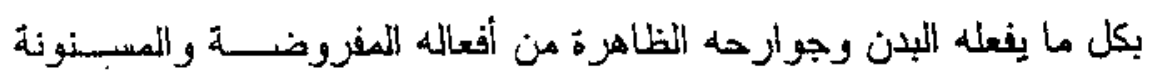
مغا.

ولهذا المسبب لم يخل الحج عند الصوفية من تتوع دلالاته المورحية

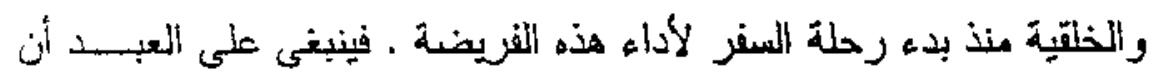

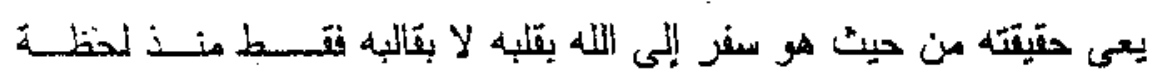

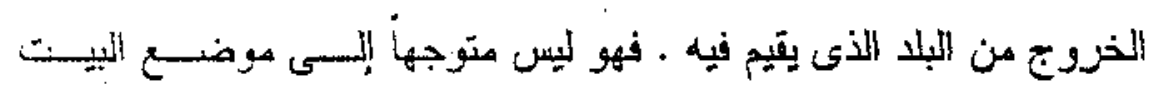

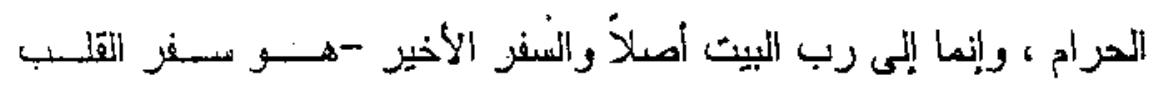

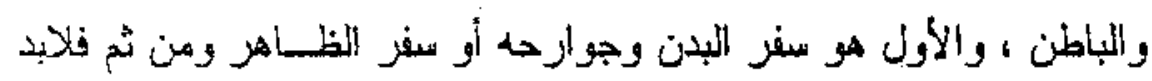

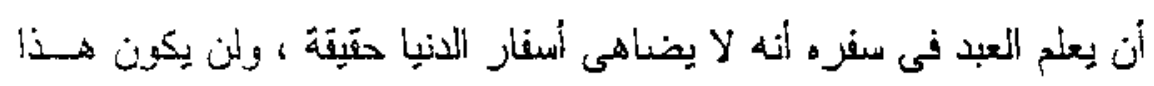

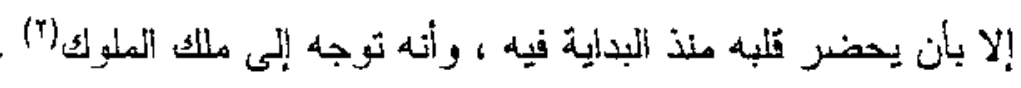

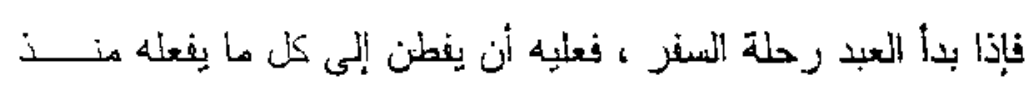

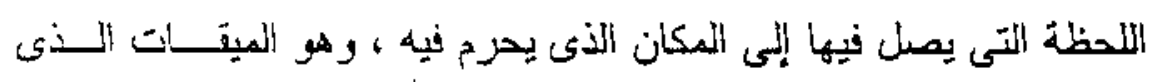

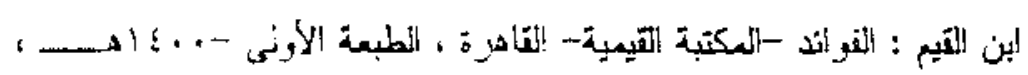
صرب

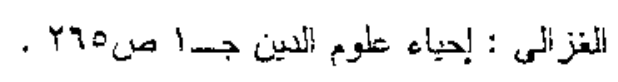


حد المشر ع ليحرم منه أهل جهة معينة ـ فإذا بلغ العبد هذا المكان فلابــــ

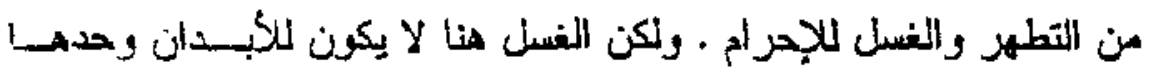
بالماء ، بل لابد معه من غسل التلوب بالتوبة|'(1) .

وإذا كان الأول ضرورة للجحرلم وطهارة الجوارح الظاهرة ، فإن

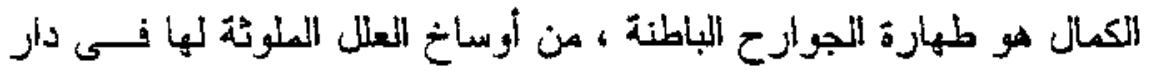

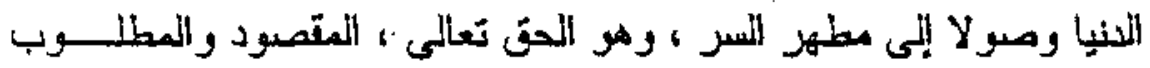

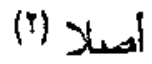

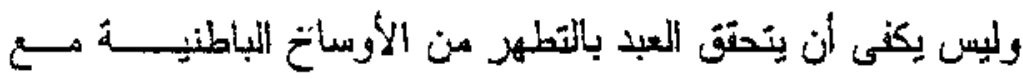

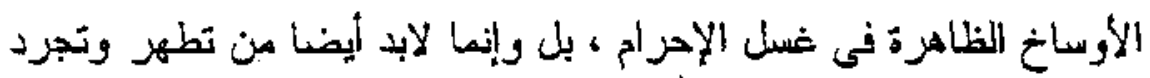

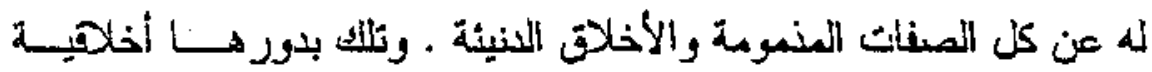

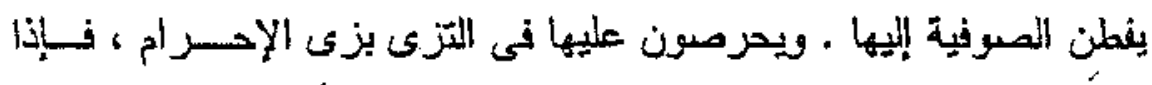

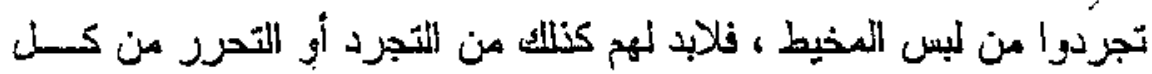

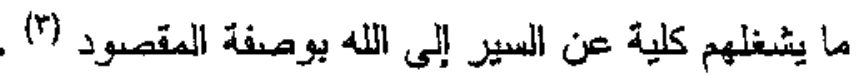

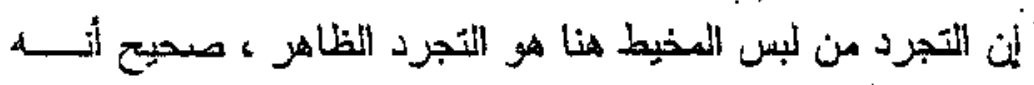

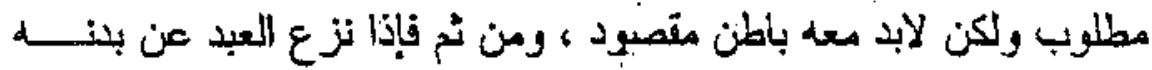

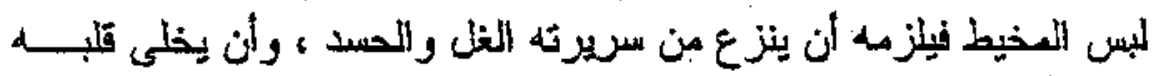

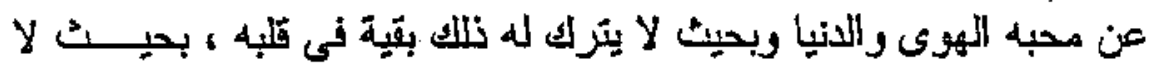

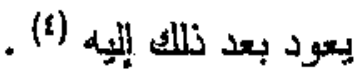

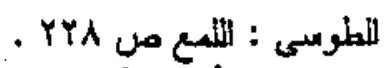

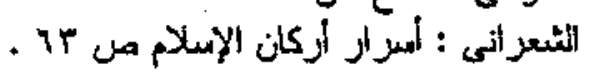

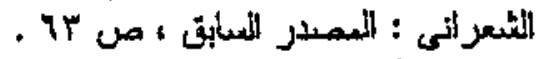

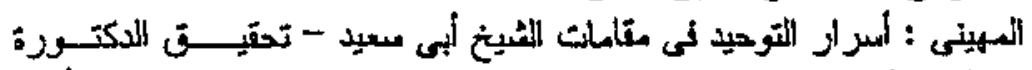

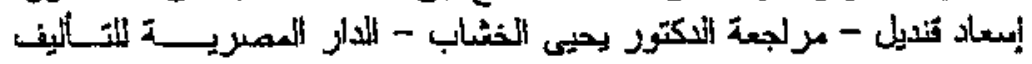

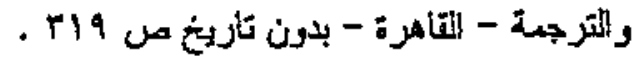


والتبلية لا تكون بمجرد النطق بها باللسان وحده ، وإنما باللنســان

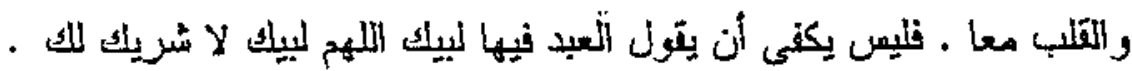

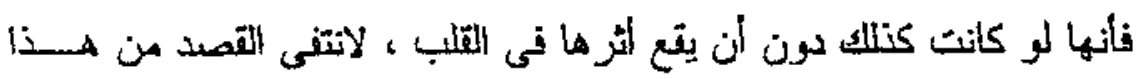

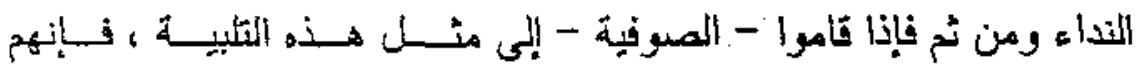

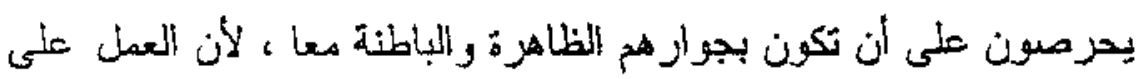

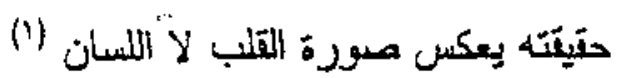
من أجل نللك إذا حققوا هذه التلبية بالسنتهم ، فقد ألزموا أنفسهم ألا

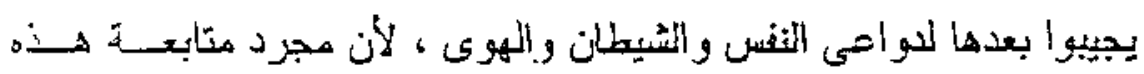

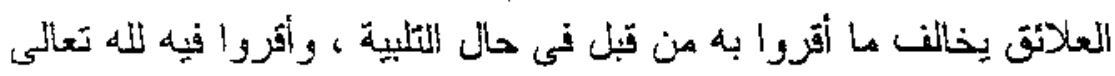

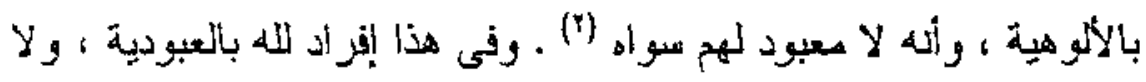

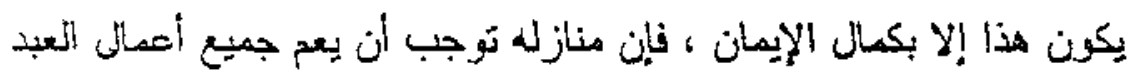

بأعضائه ألظاهرة والباطنة بكان

ولا عجب بعد نلاك كله ، حين" نجدهم يؤكدون على هذه المضشامين

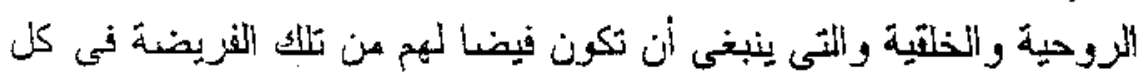

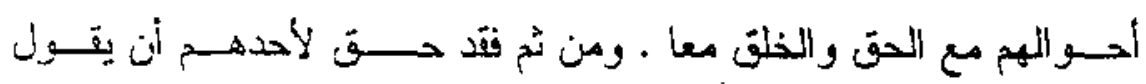

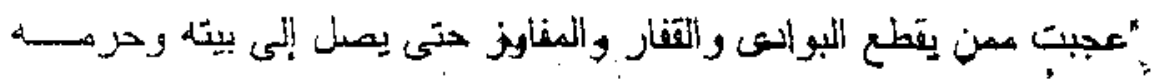

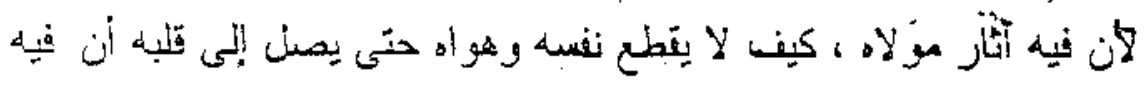

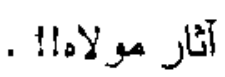

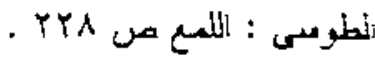

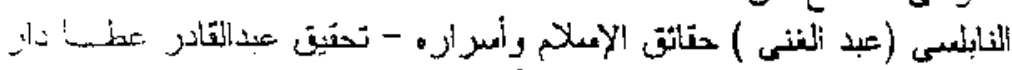

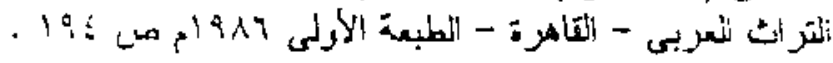

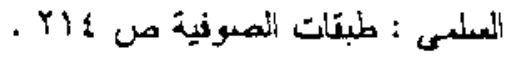


والطوات حول البيت - وهو ركن من أركان الحمج - لا يكنى فيه

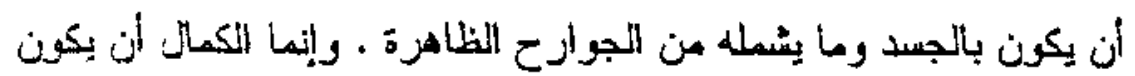

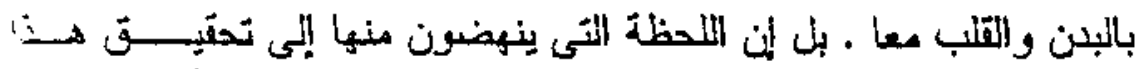

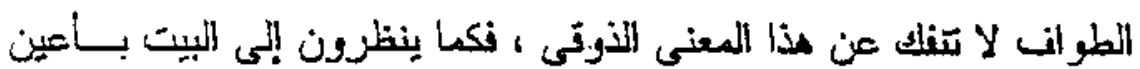

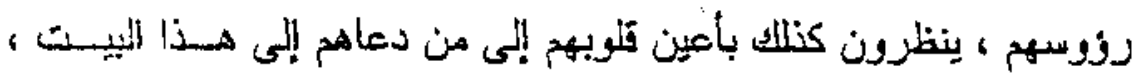

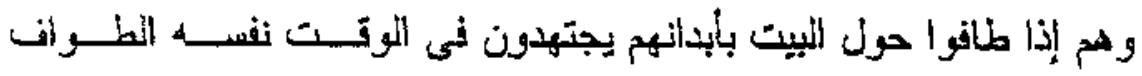
بقلوبهم (1)

فالمطوات إذأ ليس عملا آليا ينهضن به المبشن شانه بقية الأفعال المتّى

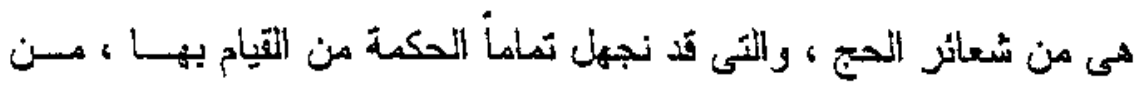

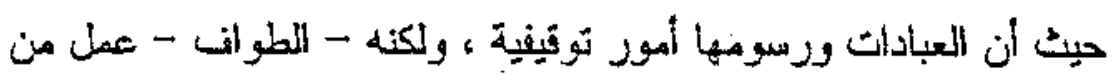

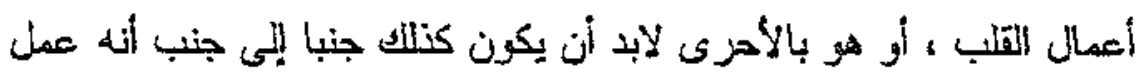

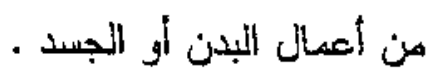

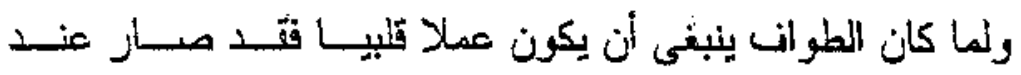

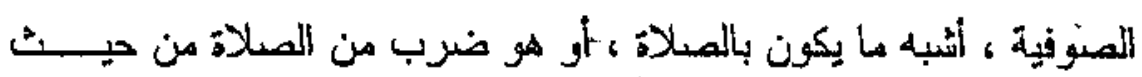

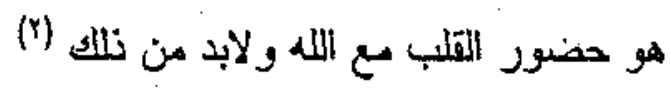

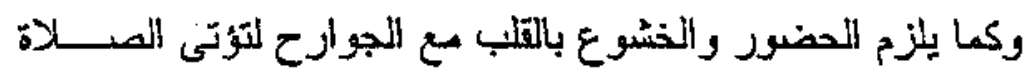

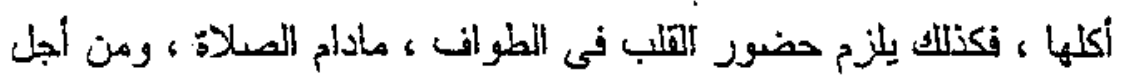
ذلك لابد فيه أيضا من التعظيم والخون والرجاء والمحبة فإذا كان الطو أف

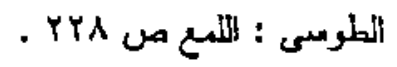




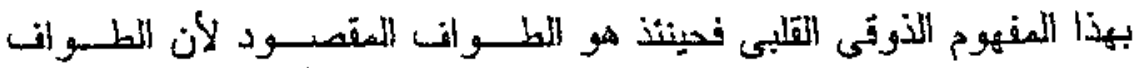

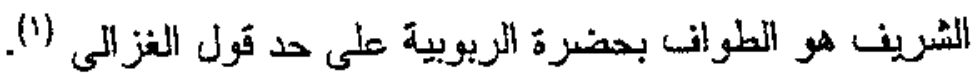

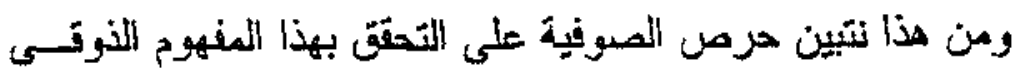
في طو الفهم ولم لا وهم الذين نذروا أنفسهم بكليتها لله تعالى وحده ، ومــن

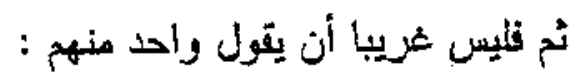

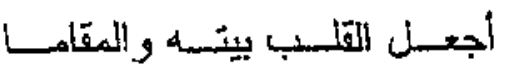

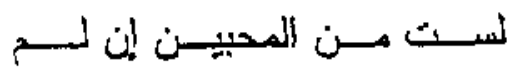
وهو ركتى إذا أردث استخانما

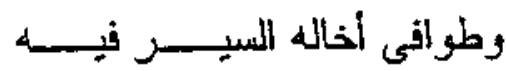

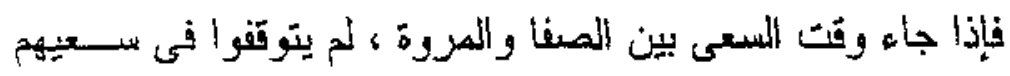
عند سعى الأبذان والأمدام ، وإنما جمعو إلميه سعى القتب و الأرو أح ، و إذا

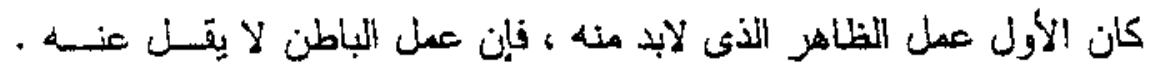

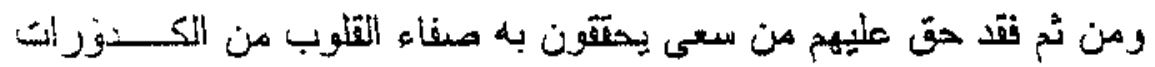

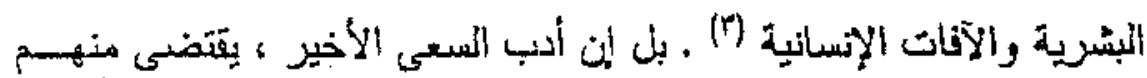

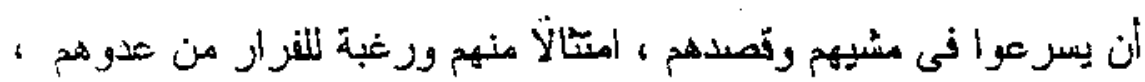

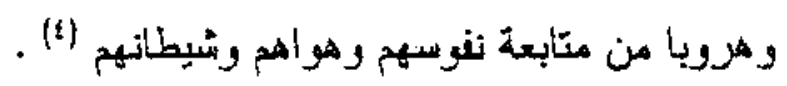
وفضلا عن هذا ، فأن أدب المسعى بين المصفا والمروة ، يلزعهم أن

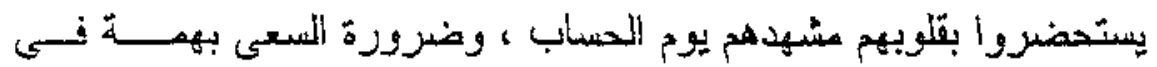

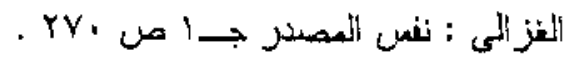

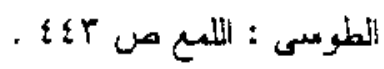

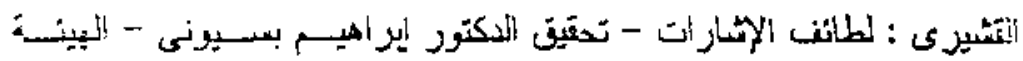

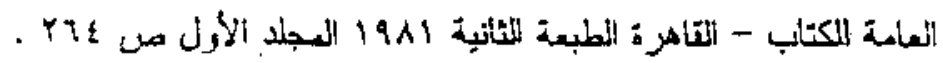

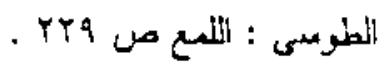


طاعة لله طلبا للغنر ان والنجاة من المذاب . ولأجل لذلك ، ينبغى أن يتنكر

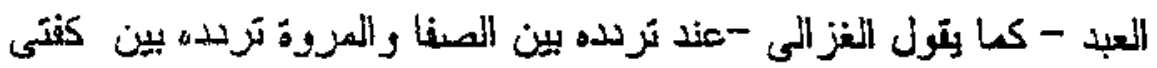

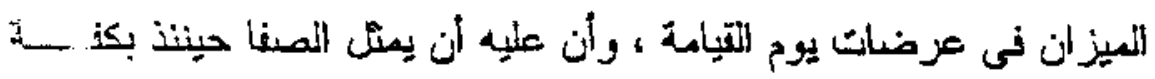

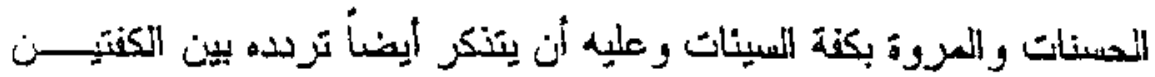

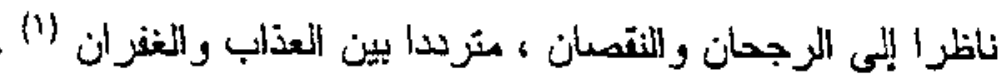
رالمقوت بعرفة من أهم أركان الحج ، بعد اللطوات بالكعبة و لأبد

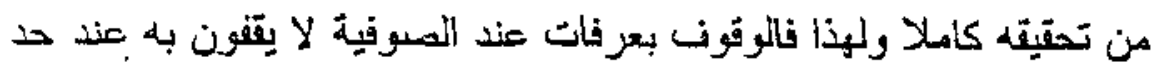

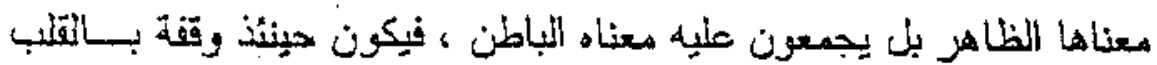

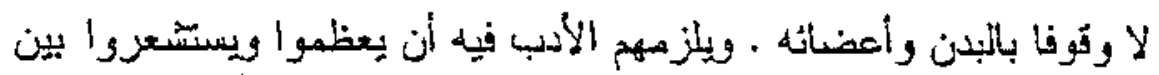

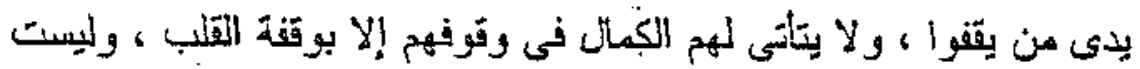

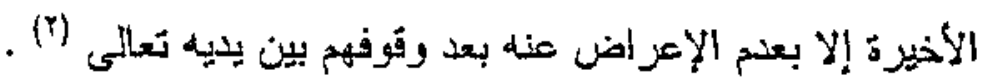
فاتوثونس بعزفات إذأ وتفة -على حذ قول الثفزى - والموقفة ينبغى

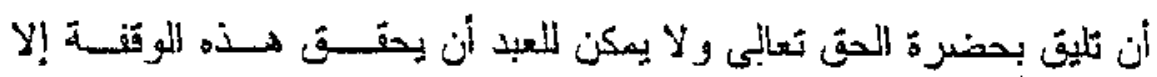

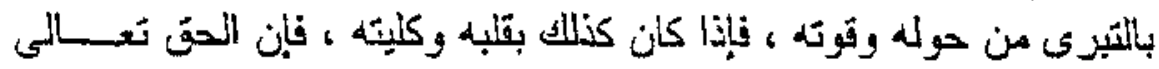

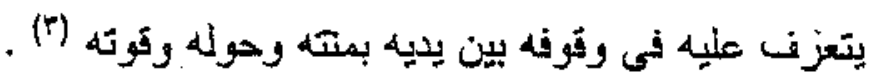

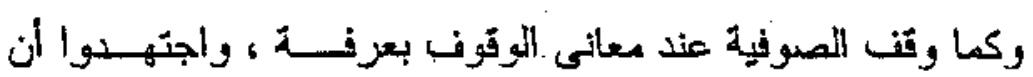

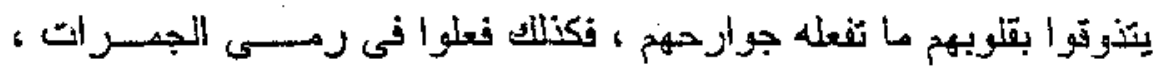

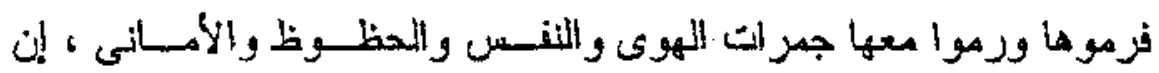

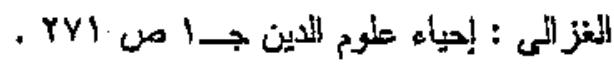

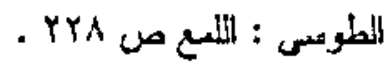


الرمى الأول هو الذى بنعلونه امتثالا لما يحدده اللهرع لأداء الفريضــــة ،

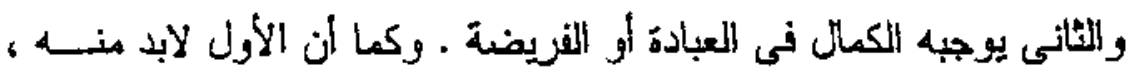

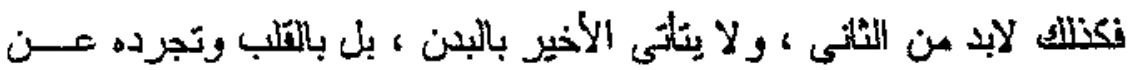
كل علامة تزبطه بالنديا (1)

بل إن الأدب الذى يحرحسون عليه فى إتيان هذه الأركان ، ينبغى

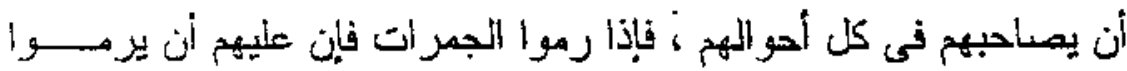

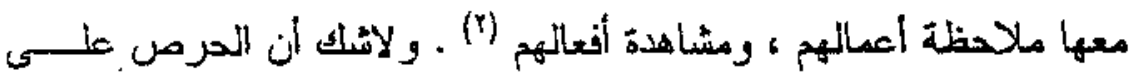

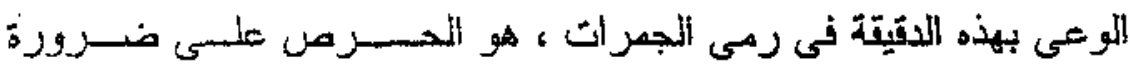

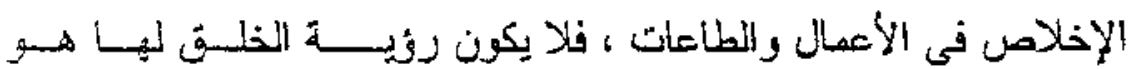

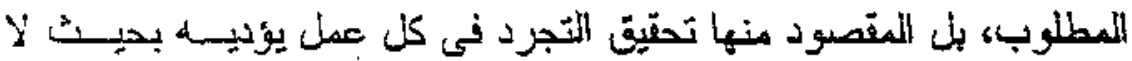

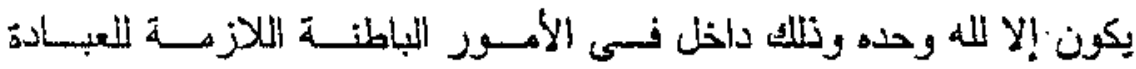

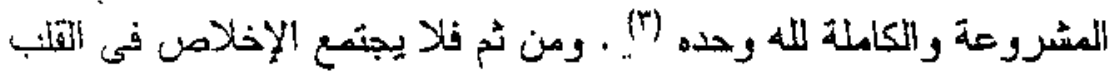

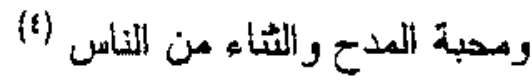

وإذا كان الإخلاص ، والمدق فيه مطلب لابد أن بعيه العبد فـــي

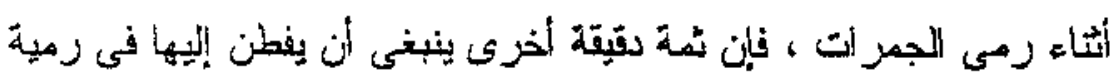
اتبلك الجمرات فيرمى بها وجه الاشيطان ، ويقصد بها حقيقة الانقياد لنأهر

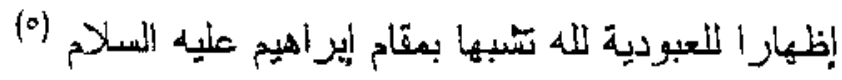

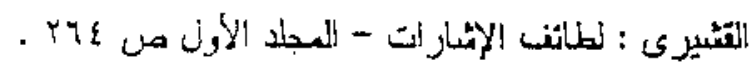

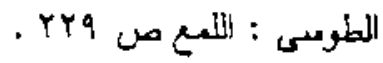

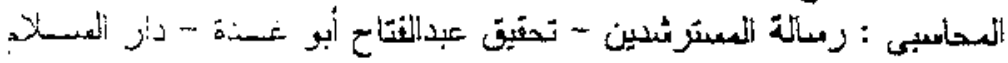

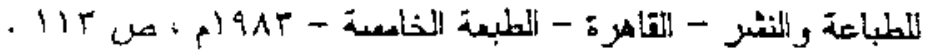

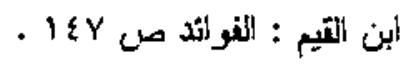

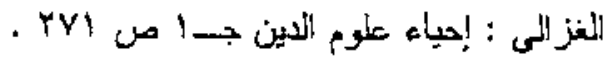


ونبح الهدى "لا يخلو أيضناً عند الصوفية من مضمونسـه الروحسى

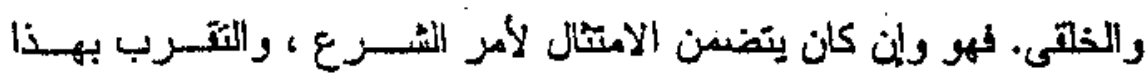

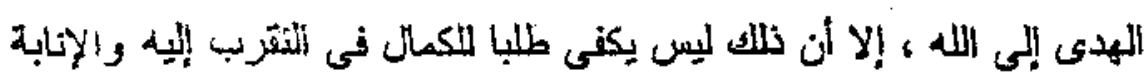

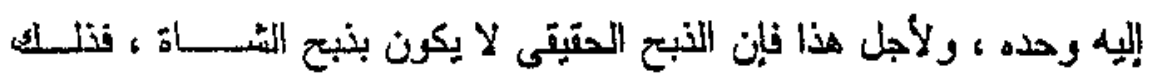

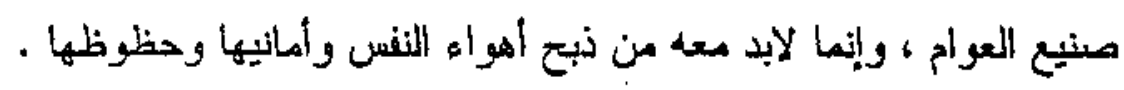

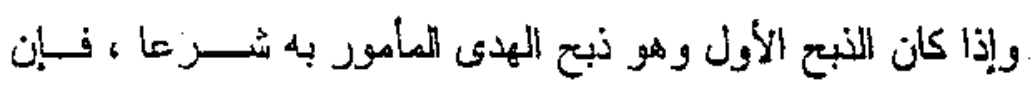

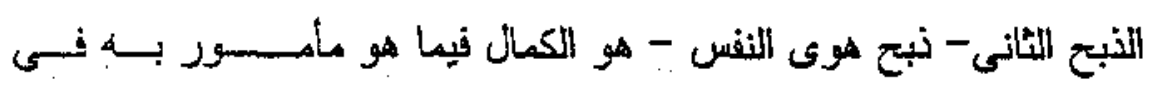

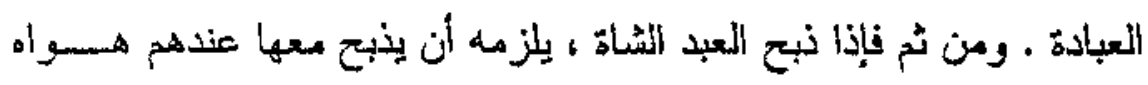

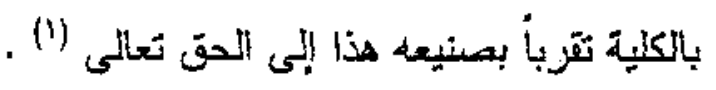

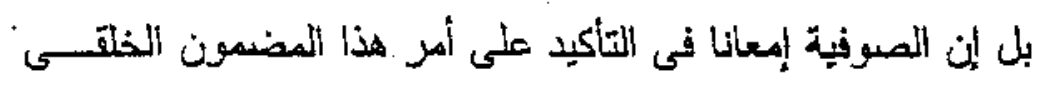

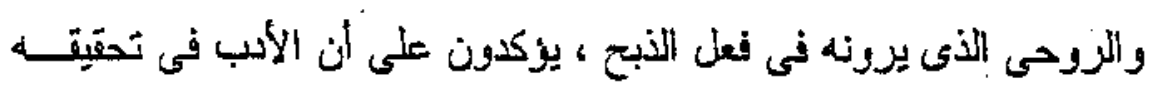

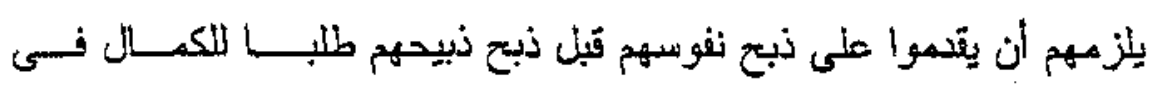

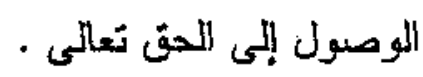

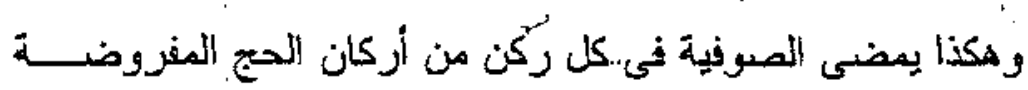

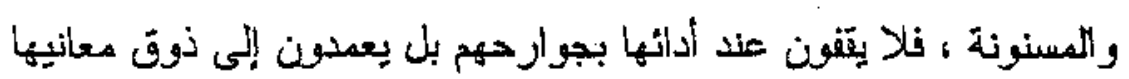

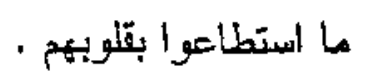

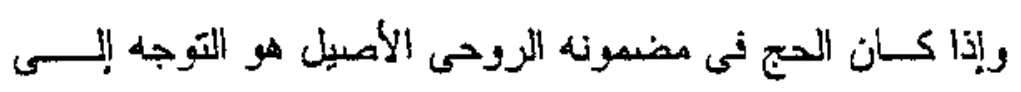

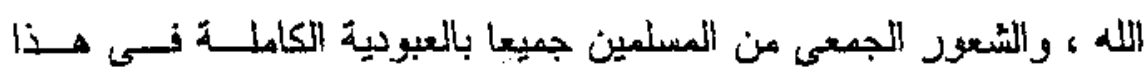

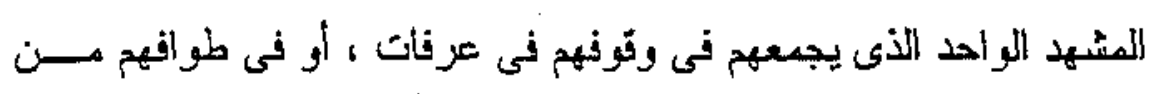

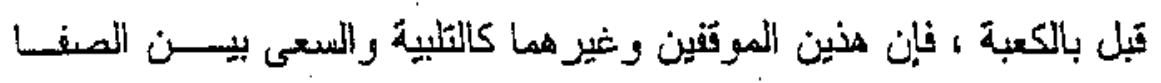




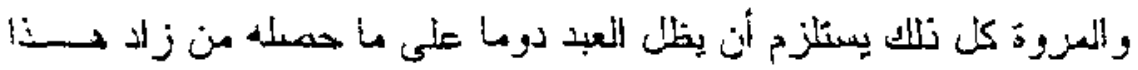

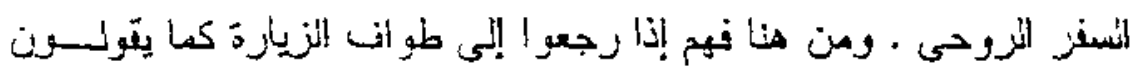

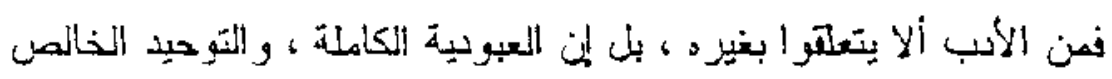

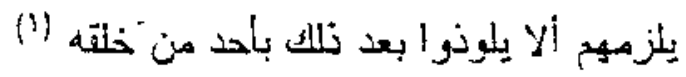

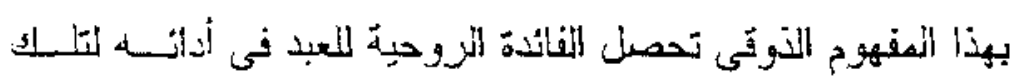

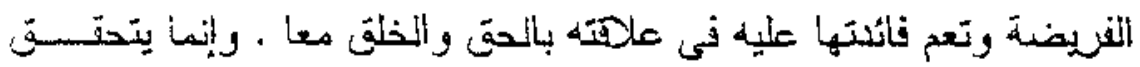

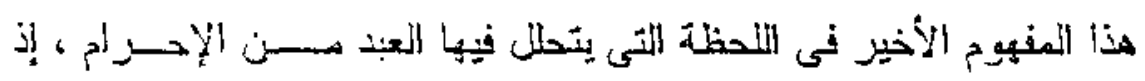

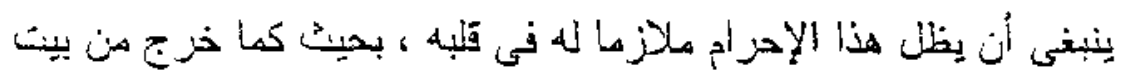

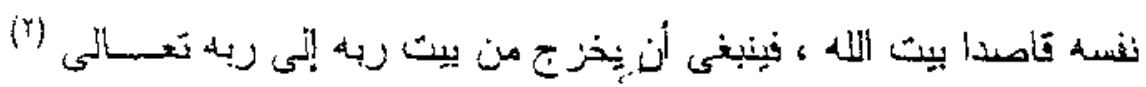

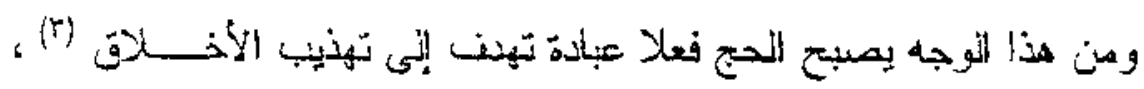
وإلا صارت مجرد تعب ونمسب لا طائل من رو اثله .

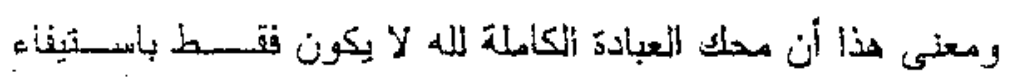

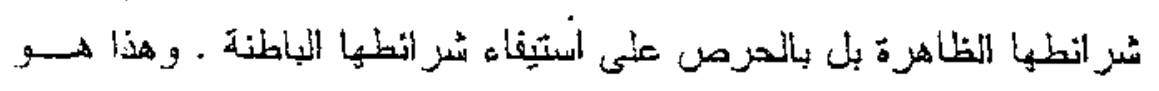

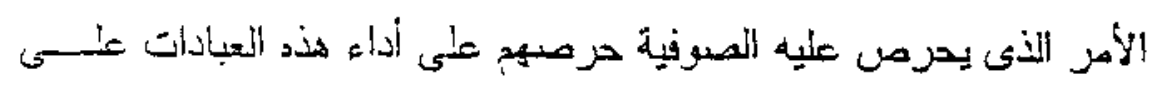

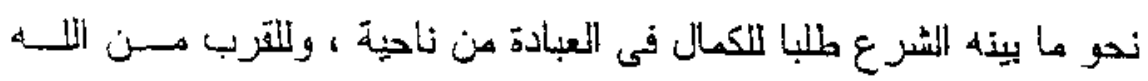

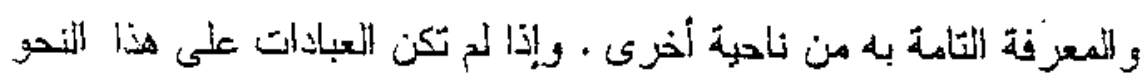

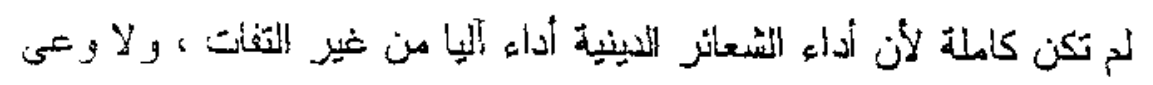

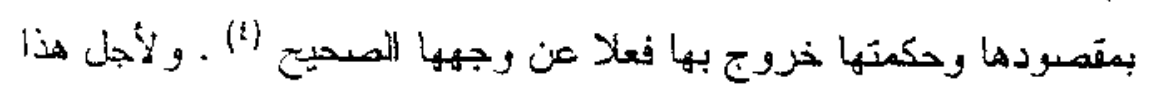

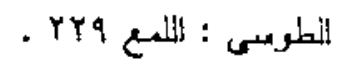

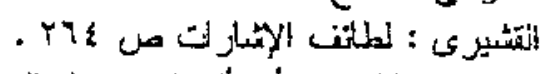

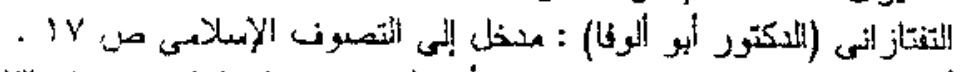

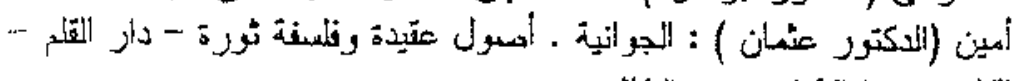

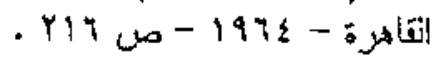




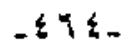

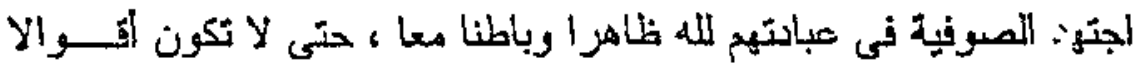

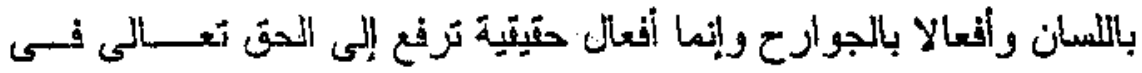

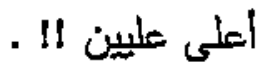

وإذا أمبحت العبادات بهذا المضمون بالذاب ، فقد حتقتت انقصـــ من أصلها وهو توكيد الألوهية والإذعان للاه وحده بالعبودية التامسـة مسن

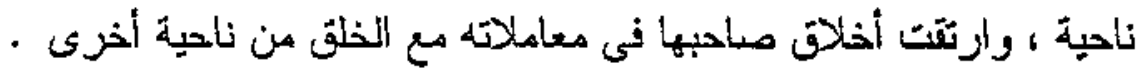
وهذا هو القصد من الدين وجوهر العبادة وسرها الأصيل . 
مصنادز ومراجي البحث

أولاً : المصــادر:

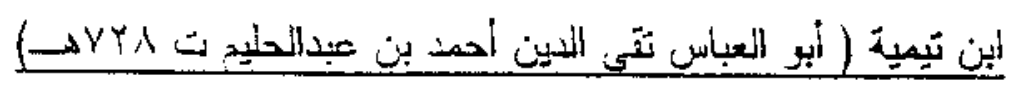

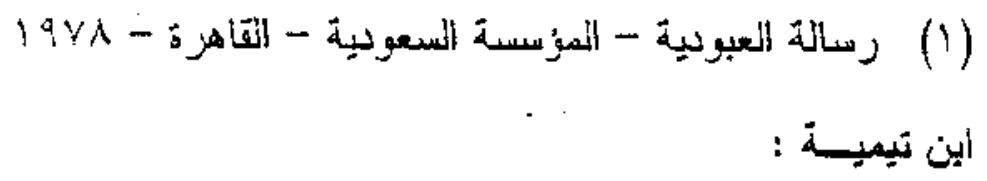

التحفة المعراقية في الأعمان التقلية - ألمكثبة النسلفية - التقــاهزة -

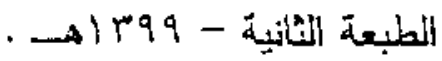

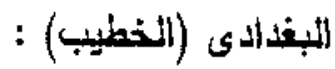

اللققة و النفيه - تحقيق إسماعيل الأنمبارى - مكثبة أنس بن هالأك. -

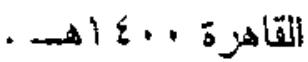

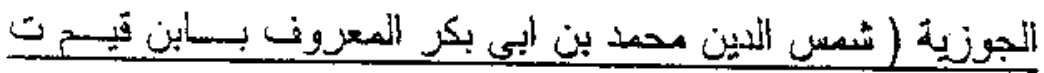
(Avo)

منتاح دار السعادة ومنشور ولاية العلموالاز الدة - صحدهـه و وعلقق

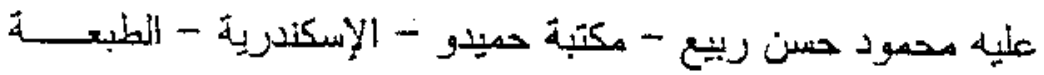

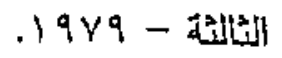$$
\text { المجوزية ( ابن قيم ) : }
$$

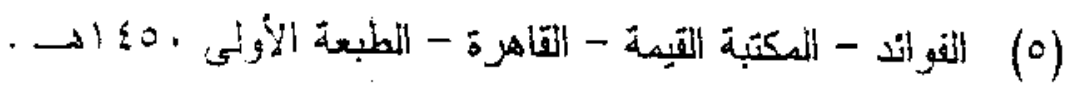

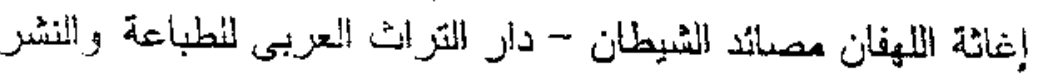

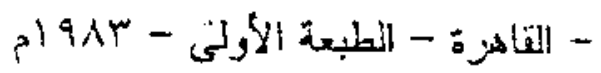




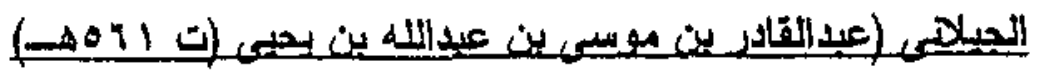

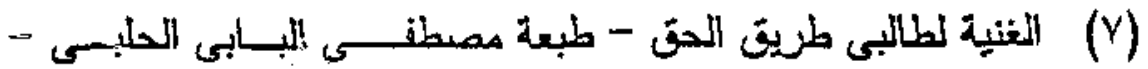

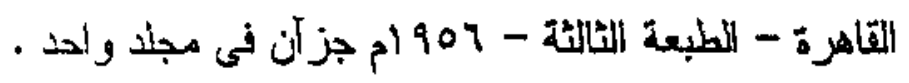

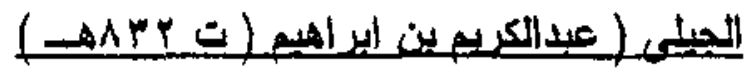

(ㅅ) الإنسان الكامل فى معرفية الأو ائل والأواخر - وبهامشية أربعة كتب

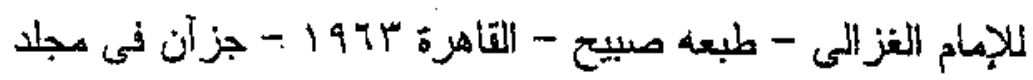
واحد .

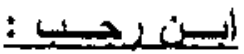

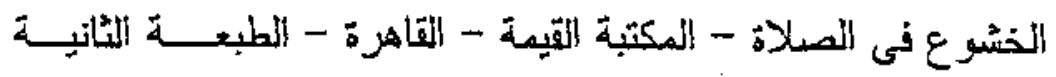

$$
1914
$$

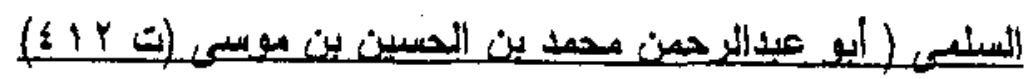

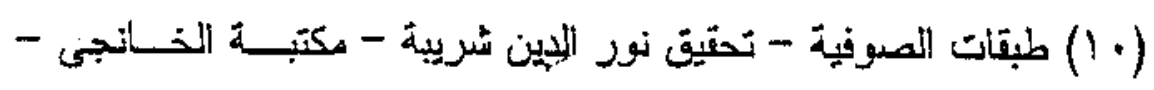

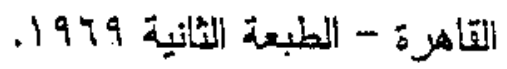

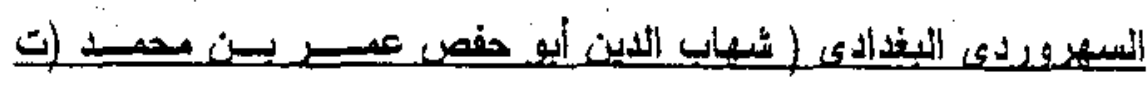
(-4TYY

(11) عوارن المعارت - دار الكتاب الغربى - بيزوت - الطبعة المثانية. -

\section{إيسين سينيا:}

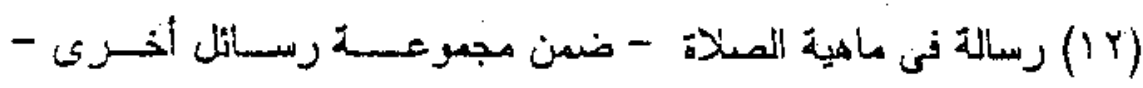

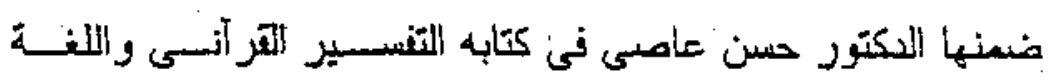




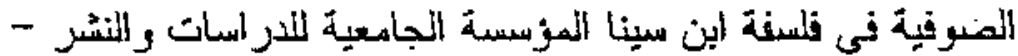

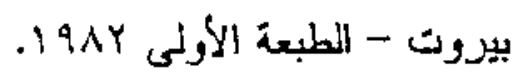

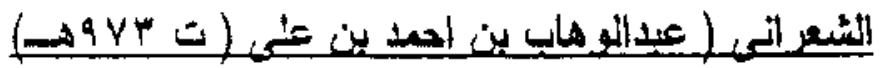

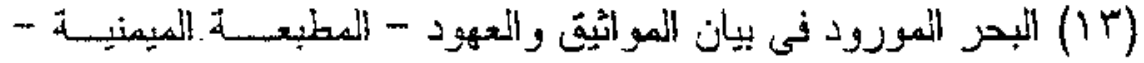

$$
\text { ألقاهرة مد - بدون ثاريخ. }
$$

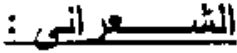

( ) أسرانر أركان الإسلام - تحقيق عبدألقادر أحمد عطا - دار التزاتث

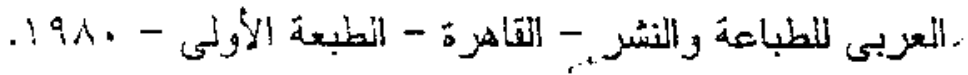

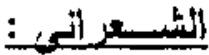

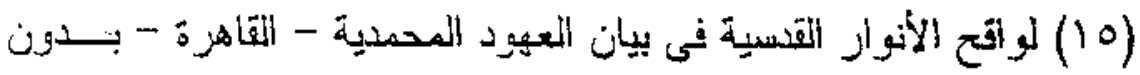
•أربن

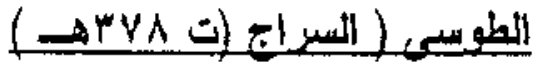

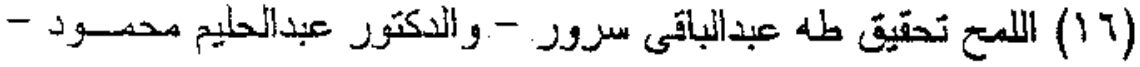

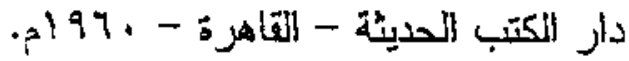

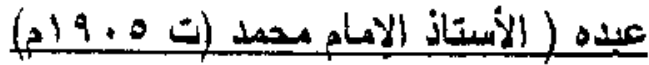

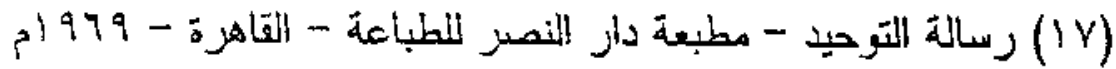

$$
\text { : }
$$

تغسير فاتحة الكتاب وجزيء عم - طبعة جزيدة الجمهورية - النقاهرة . 


\section{|المن عميية (أحمد بن محيد)}

(9 (19) الفتوحات الإلهية فى شرح المباحث الأصلية - تحقيق مبدالرحمسن

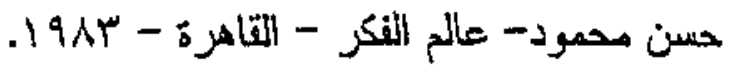

\section{الين علبــــن}

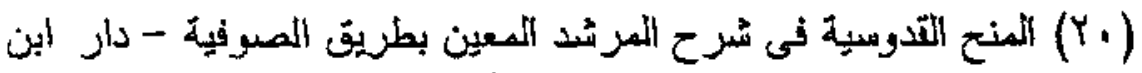

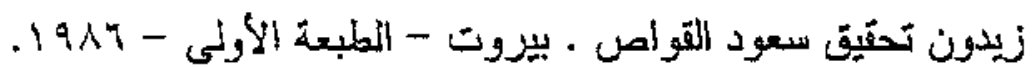

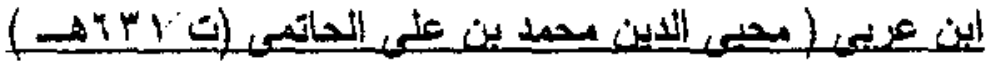

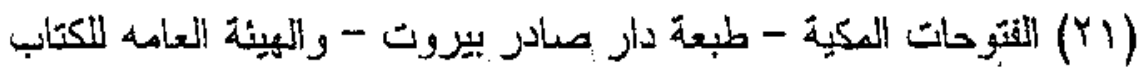

- القاهزة .

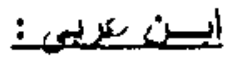

1970 - مواثع النجوم - مكتبة صيبيح - التاهرة (YY)

$$
+
$$

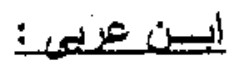

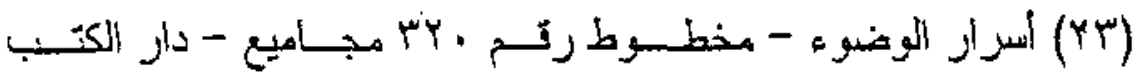

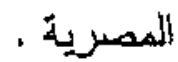

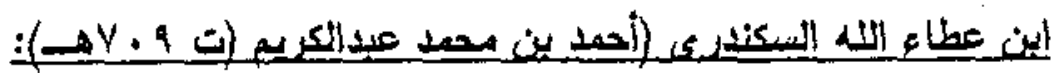

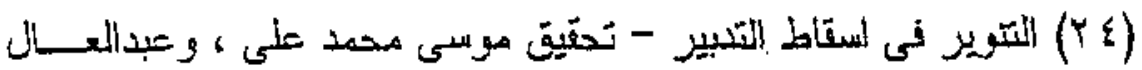

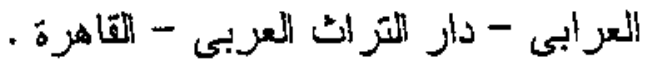

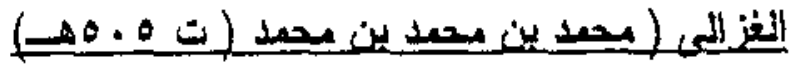

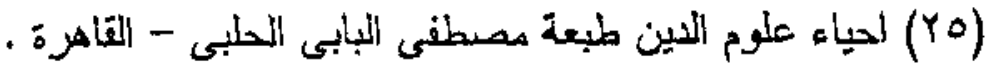




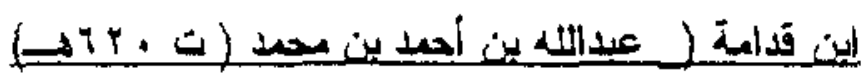

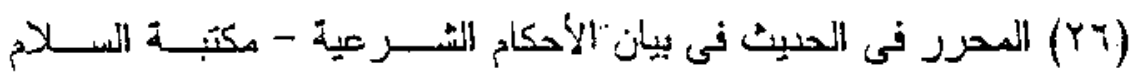

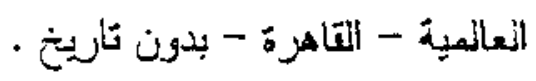

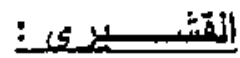

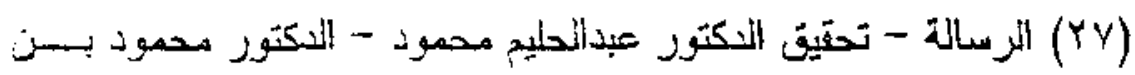

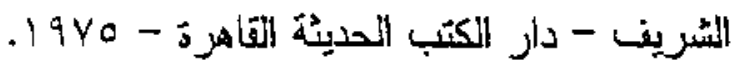

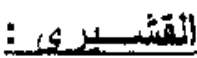

(YN)

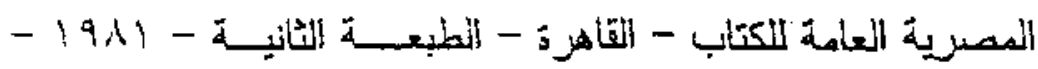

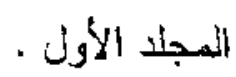

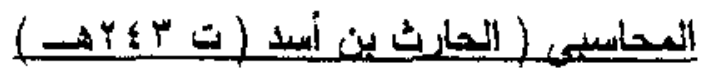

- (Y9) اللوحسايا - تحقيق عبدالقادر عطا - دار الككتب العلمية - بيزوت النطبعة الاولى - النى

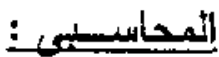

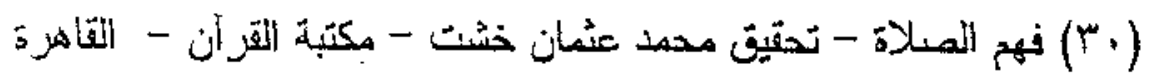

.1914

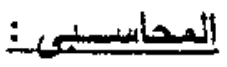

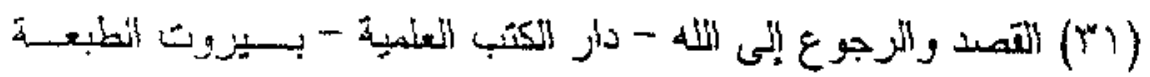

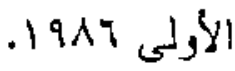




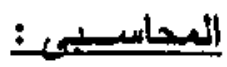

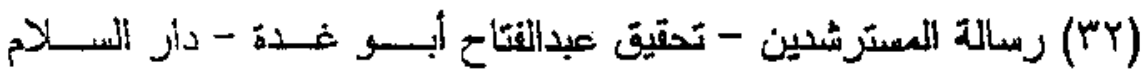

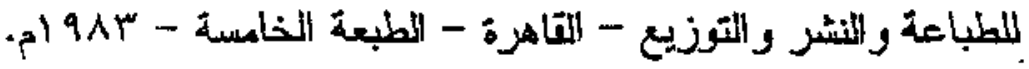

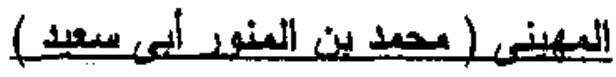

(بسب) أسرار التوحيد فى مقامأت الشيخ ابى سعيد - تحتيق إلدكتور إسعاد قنديل - مراجغعة الدكتور يحيى الخشابب - الذار المصرية للتألينس

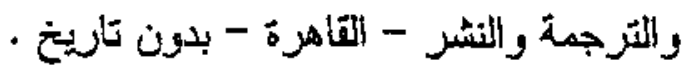

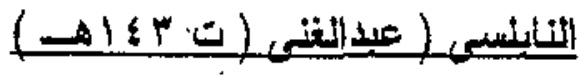

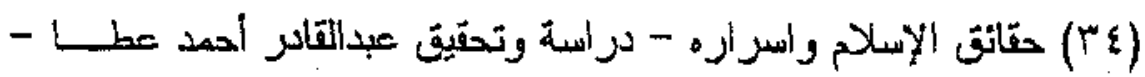

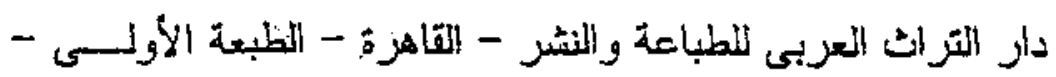
.1914

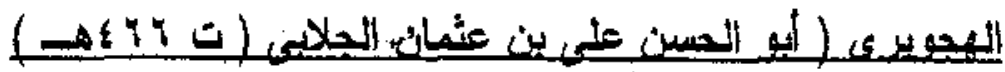

(ب0) كثنف المحجونب - تحقيق الندكتورة إبدعاد قنديل - مراجعة الدكتور

يحيى المخشاب - المجلس الأعلى المشئون الإسسلامية - القهـاهرة -

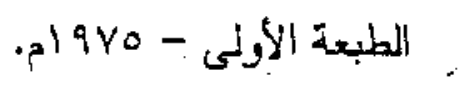

\section{$\stackrel{0}{\longrightarrow}$}

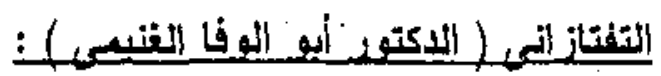

(rV) مدخل إلى التصو الإسلامى - دار المقافة للطباعة والمثشر - القاهرة 


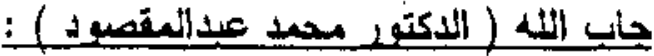

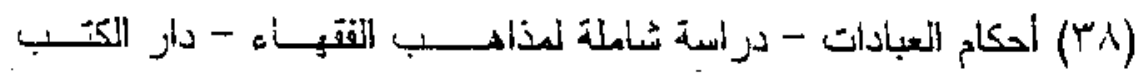
الجامعية الحديثة - طنطل - الطبعة الأولى - 1917.

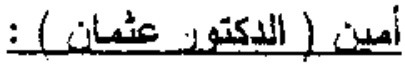

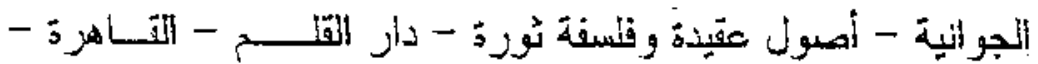
- 1978

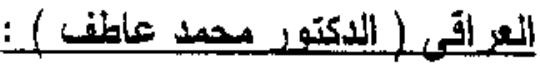

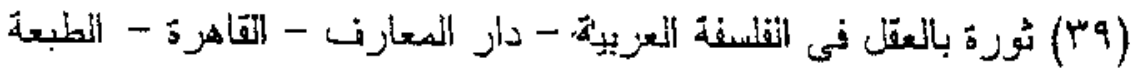

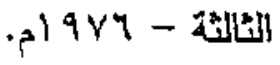

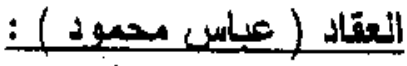

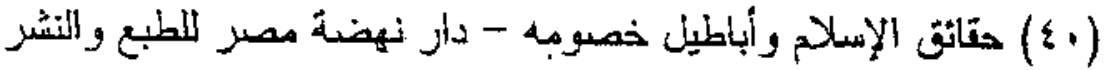

$$
\text { - }
$$

